\title{
5. SITE 450: EAST SIDE OF THE PARECE VELA BASIN
}

\author{
Shipboard Scientific Party ${ }^{1}$
}

\section{HOLE 450}

Date occupied: 3 March 1978

Date departed: 6 March 1978

Time on hole (hrs): 58

Position: $18^{\circ} 00.02^{\prime} \mathrm{N} ; 140^{\circ} 47.34^{\prime} \mathrm{E}$

Water depth (sea level; corrected m, echo-sounding): 4707

Water depth (rig floor; corrected m, echo-sounding): 4717

Penetration (m): 340

Number of cores: 36

Total length of cored section (m): 340

Total core recovered $(\mathrm{m}): 183.3$

Cored recovery $(\%): 54$

Oldest sediment cored:

Depth sub-bottom $(\mathrm{m}): 333.0$

Nature: Hydrothermally altered vitric tuffs

Age: Middle Miocene (NN 5)

Measured velocity $(\mathrm{km} / \mathrm{s}): 2.1$

Basement: Not reached; intrusive basalt encountered at $333.0 \mathrm{~m}$ Measured velocity $(\mathrm{km} / \mathrm{s}): 5.2$

Principal results: Located on the eastern side of the Parece Vela Basin, Site 450 was drilled successfully to a depth of 340 meters sub-bottom. The upper 333.0 meters comprise a sedimentary section consisting of pelagic clays, vitric tuffs, and fine vitric tuffs. The basal 7.0 meters are intrusive basalt. Mechanical difficulties forced termination of the drilling. The sedimentary section is Pleistocene to middle Miocene and is conveniently divided into two units - an upper pelagic clay and a lower tuff. These two units can each be further divided into sub-units from the top downward: Sub-unit la is 26.5 meters of dark brown pelagic clay with minor disseminated volcanic glass, barren except for a meager lowerPleistocene radiolarian fauna in Section 1-1. Sub-unit 1 b is 57.0 meters of middle to upper Miocene dark yellowish brown, dark grayish brown, and dark gray ash-rich pelagic clay with minor dark to very dark ash beds. Dominating the sedimentary column, Sub-unit 2a is 241.0 meters of middle Miocene dark gray, fine vitric tuffs, in some places nannofossil-bearing, and paler, with

\footnotetext{
${ }^{1}$ Loren Kroenke (Co-Chief Scientist), Hawaii Institute of Geophysics, University of Hawaii, Honolulu, Hawaii; Robert Scott (Co-Chief Scientist), Department of Geology, Texas A\&M University, College Station, Texas; Kathy Balshaw, Department of Geology, Rice University, Houston, Texas; Simon Brassell, School of Chemistry, University of Bristol, Bristol, United Kingdom; Pierre Chotin, Laboratoire de Géologie Structurale, Université Pierre et Marie Curie, Paris, France (now at: Departement de Geologie, Université Mohammed V, Rabat, Morocco): Mary E. Heiman, Stratigraphy Laboratory, Mobil Oil Company. Dallas, Texas (now at: F and H Biostratigraphic Associates, Laramie, Wyoming): Teruaki Dallas, Texas (now at: F and Hestre Istil, Ocean Research Institute, University of Tokyo, Tokyo, Japan; Barbara H. Keating, Hawaii Institute of Geophysics, University of Hawaii, Honolulu, Hawaii; Erlend Martini, Geologisch-Paläontologisches Institut, Johann-Wolfgang-Goethe-Universität, Frankfurt am Main, Federal Republic of Germany; David P. Mattey, Department of Geology, Bedford College, University of London, London, United Kingdom (present address: Department o Geological Sciences, University of Birmingham, Birmingham, England); Kelvin Rodolfo, Department of Geological Sciences, University of 1llinois, Chicago, Illinois; Renzo Sartori, Laboratorio di Geologia Marina del C.N. R., Bologna, Italy: Fritz Theyer, Hawaii Institute of

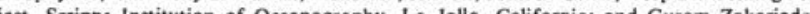
ject, Scripps Institution of Oceanography, La Jolla, California; and Guram Zakariadze. Institute of Geology, Georgian Academy of Sciences, Tbilisi, U.S.S.R. (now at: V.I. Vernadsky Inst. of Geochem. and Analyt. Chem., U.S.S.R. Acad. of Sciences, Vorobyewskoe chaussee 47A, 117334 Moscow, U.S.S.R.).
}

minor gray and black vitric tuffs and rare tuffaceous volcaniclastic conglomerates. Sub-unit $2 \mathrm{~b}$ is 8.5 meters of the same fine vitric tuff as Sub-unit 2a, except that hydrothermal alteration has increased the zeolite content and discolored the sub-unit reddish brown. Sub-unit $2 \mathrm{c}$ is $1 \mathrm{~cm}$ of pale yellowish white, fine vitric tuff forming a baked contact with the underlying intrusive plagioclaseclinopyroxene-olivine-phyric intrusive pillow basalt. Between and within the basalt pillows are fragments of green, contact-metamorphosed tuff. Based upon reflection profiles, the intrusive body is small; contact relations suggest that it intruded unconsolidated ashes close to the sediment surface, forming pillowlike shapes. Basement was not reached, and its age remains undetermined.

\section{BACKGROUND AND OBJECTIVES}

Because the age and origin of the eastern Parece Vela Basin have not been clearly established by Sites 53 and 54 , Site 450 was selected with the objective of drilling through the sediment wedge covering the eastern Parece Vela Basin into basement to dispel the ambiguities related to this area.

The eastern Parece Vela Basin is bounded on the west side by the Parece Vela Rift (Mrozowki and Hayes, 1979), on the east side by the West Mariana Ridge, on the north side by the Shikoku Basin, and on the south side by the junction of the Mariana Trench and the Yap arc-trench system (Fig. 1). Karig (1975) has identified the Parece Vela Basin as an early-Miocene back-arc marginal basin and the West Mariana Ridge as a remnant arc. The Parece Vela Rift is a good candidate for a spreading center, if we assume a symmetrical spreading pattern, but this hypothesis still remains to be proven because basement ages are uncertain. Westward from the West Mariana Ridge, a thick wedge of sediment extends over most of the eastern side of the Parece Vela Basin, where it inundates the rough basement and is dammed by a series of north-south trending basement ridges near the IPOD Trough (one of a series of troughs forming the Parece Vela Rift). Sites 53 and 54 were drilled into this sediment wedge (Fischer, Heezen et al., 1971); both holes were drilled on top of high basement features and both reached basaltic rocks at 201 and 297 meters sub-bottom, respectively. Although evidence is scanty, an intrusive origin is hypothesized for the basalt and andesite(?) at Site 53 and an extrusive origin for the basalt and overlying carbonate-cemented glassy breccia at Site 54. Although the basalts recovered at both these drill sites are highly altered, dredge samples collected by the International Working Group on the IGCP Project "'Ophiolites”' (1977) from the Parece Vela Rift (see Site 449 report, Fig. 1, this volume) include fresh basalts and gabbros that appear to be chemically similar to midocean ridge (MOR) basalts (Dietrich et al., 1978; Guram Zakariadze, personal communication). 


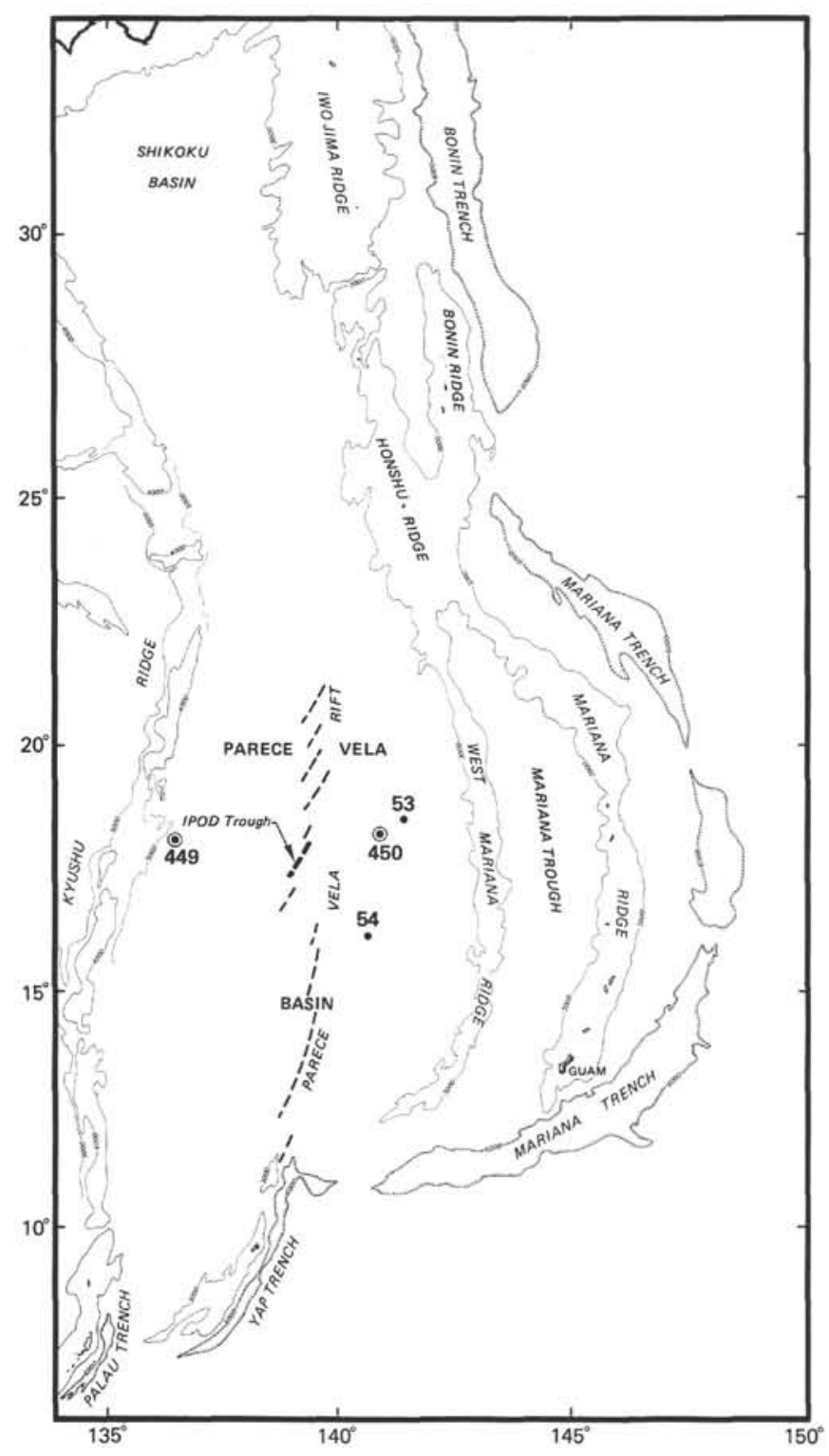

Figure 1. Positions of DSDP Sites 450, 53, and 54 in the eastern Parece Vela Basin. (A concentric circle indicates Site 450; solid circles indicate Sites 53 and 54.)

Because the acoustic basement is interpreted to be about 500 meters sub-bottom or more, what is the significance of encountering volcanic rocks at 200 and 300 meters sub-bottom? Is this oceanic basement or marginal-sea basement? In the case of Site 53, with possible intrusive relations, obviously true oceanic basement was not reached. But at Site 54, could block faulting have elevated the basement? Could sedimentation off an active remnant arc have created a sediment wedge so rapidly that it buried the active spreading center of its back-arc marginal basin?

Detailed site surveys conducted by the LamontDoherty Geological Observatory (L-DGO) and Scripps Institution of Oceanography (SIO) in the vicinity of Site 450 reveal the presence of broad basement ridges roughly trending north-south, exposed in the western part of the surveyed area (Fig. 2). The thick sedimentary wedge against the west side of the West Mariana Ridge probably consists of turbidites composed of volcanic debris originating from that ridge. These turbidites have inundated most of the basement ridges, thus the topographic expression of basement ridges left exposed may only appear to be continuous in a roughly north-south direction. Preliminary mapping of the inundated basement (Fig. 3) indeed suggests that the ridges might be oriented or trend in a more northeasterly direction, at least in the surveyed area.

In the eastern part of the surveyed area, sediments appear to be acoustically well-stratified and so thick that, in single-channel seismic-reflection profiles, basement is not detected below the thicker deposits. In the vicinity of Site 450 , long furrows observed in the seafloor appear to be formed by undulation of the underlying strata, as revealed in the reflection profiles. This undulation may be caused by recent fault movements that gently folded the sediment. Furthermore, because the folds extend to the surface, the deformation is thought to have occurred subsequently to deposition and therefore is interpreted as postdating either cessation of volcanic activity along the arc or perhaps subsidence of the sediment source, which, in either case, is postulated to be the West Mariana Ridge.

Within the surveyed area, basement velocities determined from sonobuoy refraction measurements range from 4.8 to $5.6 \mathrm{~km} / \mathrm{s}$, which is appropriate for oceanic Layer 2 (Langseth and Mrozowski, this volume). For Layer 3, velocities are also reported to range from 6.6 to $7.0 \mathrm{~km} / \mathrm{s}$. Magnetic anomalies are of low amplitude in the vicinity of Site 450 (Fig. 4) and seem to be much more subdued than those in the vicinity of Site 449 (see Site 449 report, this volume), which have been tentatively correlated with the Cenozoic geomagnetic time scale (Fig. 5).

The broad objectives of Site 450 were to determine basement age and origin as well as the source and depositional history of the thick sediment wedge to the west of the West Mariana Ridge that inundates the rough basement terrain on the eastern side of the Parece Vela Basin. These objectives also included establishing whether or not shallow hyperbolic reflectors suggestive of piercements were of intrusive origin. Specific critical questions that we addressed were: Does the basement age in the eastern Parece Vela Basin conform to a symmetrical or an asymmetrical spreading model? Is the chemistry of the basement comparable to mid-ocean ridge (MOR) chemistry or to that of the Mariana Trough, an active back-arc basin (Hart et al., 1972)? Are the intrusive bodies encountered of mid-ocean ridge, back-arc basin, seamount, or island-arc affinities? Is the wedge of sediment the debris from volcanic activity on the West Mariana Ridge remnant arc? What role does the presence of such a wedge of volcanic debris play in metallogenesis (Bonatti et al., 1979)? The site was actually selected because of a feature that in seismic-reflection profiles from site survey data appeared to shipboard scientists to be either a narrow basement high created by faulting prior to sedimentation or possibly a small intrusive body, as found in the 


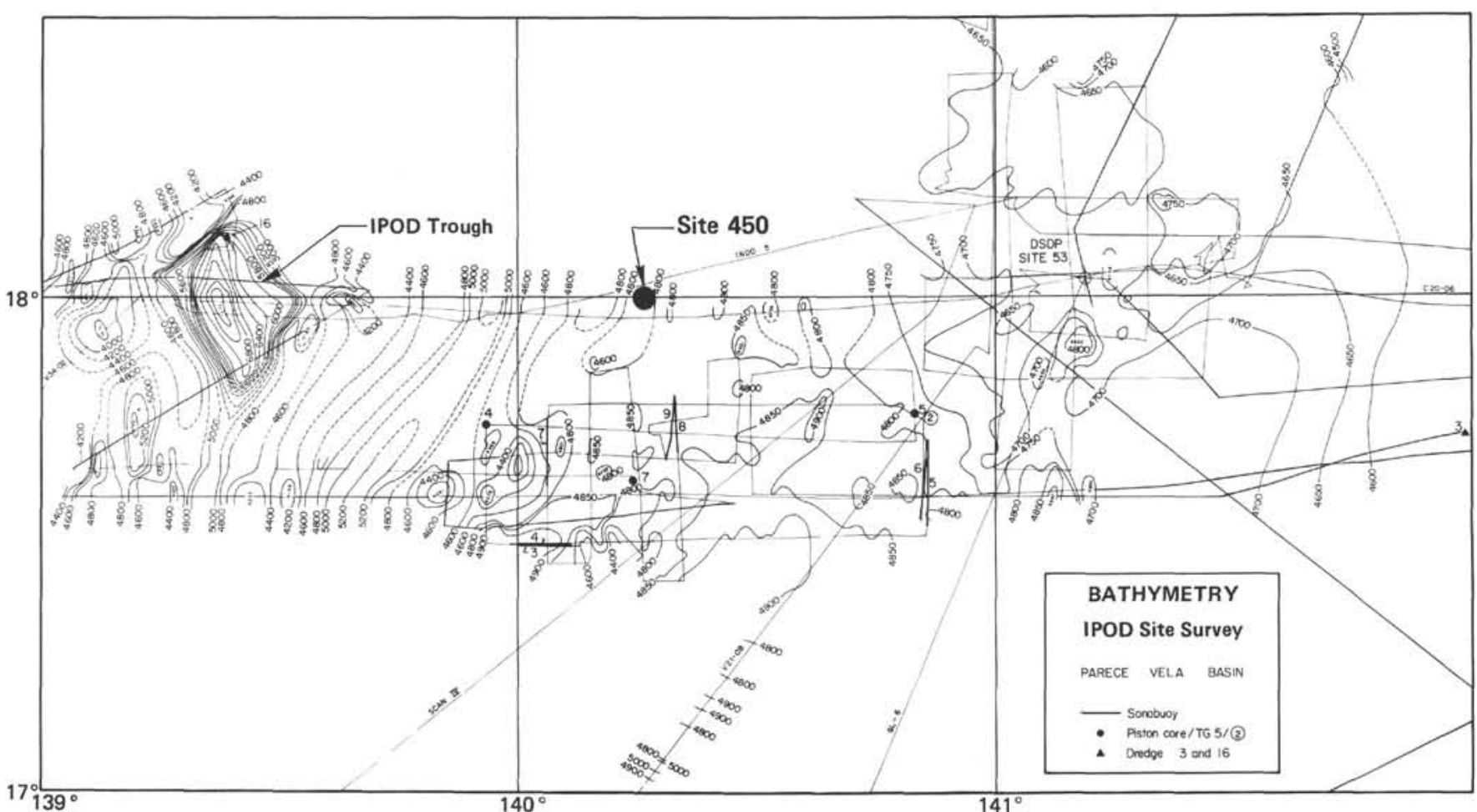

Figure 2. Bathymetry in the vicinity of Site 450 (L-DGO Site Survey data) showing sonobuoy, piston core, and dredge positions. (Track lines are shown. Dashed bathymetric contours indicate inadequate data on the western part of the map. Solid dots with a number and a circled number indicate the core number and heat-flow station, respectively.)

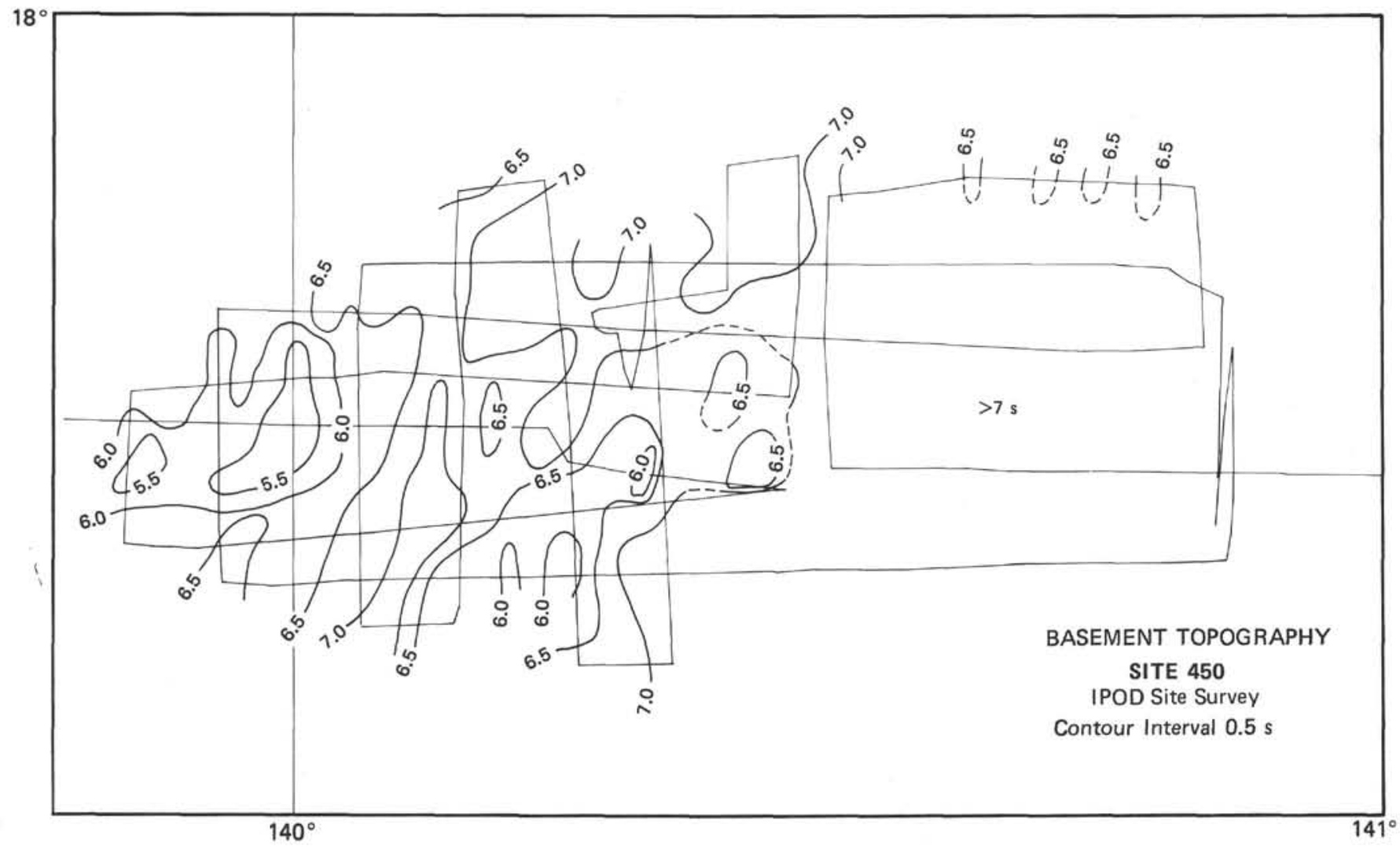

Figure 3. Basement topography in the vicinity of Site 450 (L-DGO Site Survey data). (Contour interval is $0.5 \mathrm{~s}$ of the two-way travel time. A general northeast trend to the basement blocks is suggested.) 


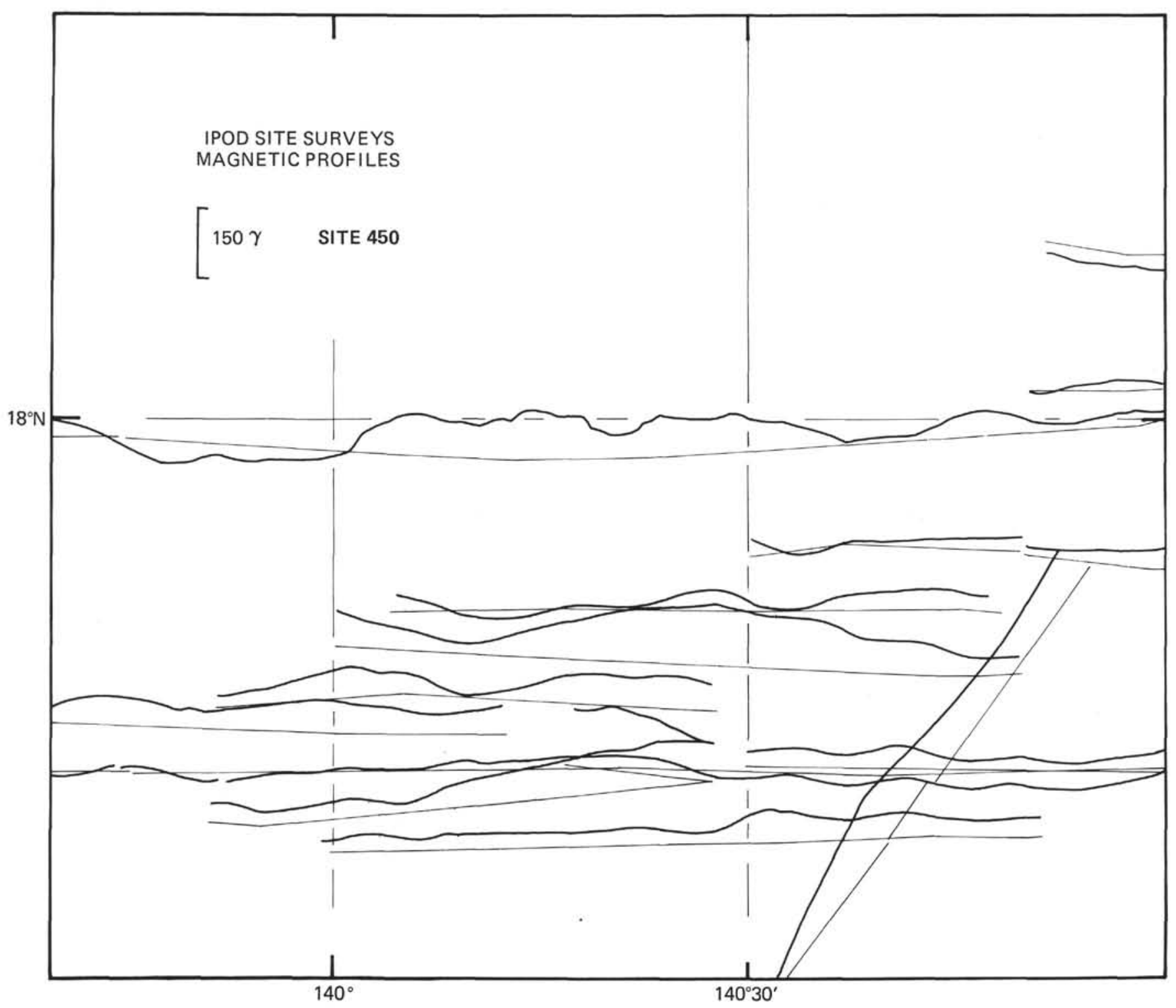

Figure 4. Magnetic-anomaly profiles in the vicinity of Site 450 (L-DGO Site Survey data). (Although the amplitudes of the magnetic anomalies are very low, a north-south lineation is discernible.)

Shikoku Basin during Leg 58 (Klein, Kobayashi, et al., in press); if it was the latter, then the basement objective could not be reached.

The immediate objective of Site 450 was to penetrate the sediment wedge and drill into acoustic basement as far as possible to determine basement origin and age.

\section{OPERATIONS}

Site 450, the second site in the Parece Vela Basin, is located approximately $320 \mathrm{~km}$ due east of Site 449 and $450 \mathrm{~km}$ west of Pagan Island in the Mariana Archipelago. During the transit between Sites 449 and 450, the freshest winds of the entire cruise were encountered, and average speed was held to 7.1 knots. Just before the site was approached, we experienced some difficulty in navigation related to the fact that all navigational instrumentation was temporarily out of commission and the weather was too cloudly for celestial fixes. The
LORAN C and satellite navigation units were restored to service, however, as the ship entered the immediate area of the site. Because no useable satellite passes were forecast for several hours, the final approach was made solely on the basis of LORAN and bathymetry.

The vessel passed over the drill site, changed to a reciprocal course, and dropped the beacon on the second pass (Fig. 6). During the retrieval of seismic gear, we were delayed for about one-half hour when the handling cable for the 120-cubic-in. air gun was found to be severed near its attachment point at the air-gun end.

The designated site position was over a pinnacle, interpreted to be a narrow basement horst on the basis of presite surveys; penetration to this pinnacle, which was visible on the Challenger seismic-reflection profile, was necessary if we were to reach basement in the allotted time. After the ship was positioned over the beacon, it was displaced 300 meters to the east-southeast in order 


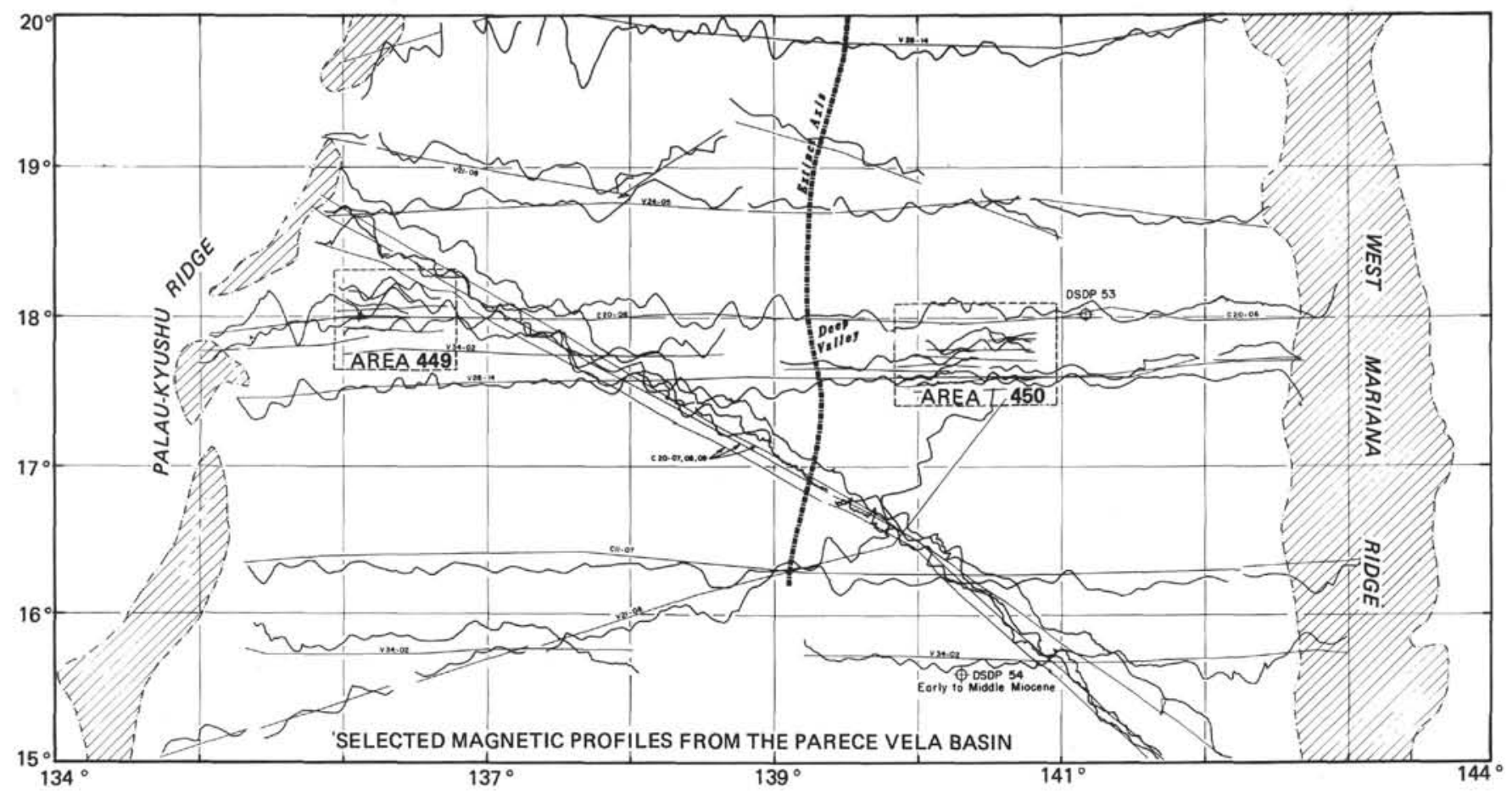

Figure 5. Selected regional magnetic-anomaly profiles along east-west tracks across the entire Parece Vela Basin (L-DGO Site Survey data). (The Palau-Kyushu and West Mariana Ridges are shaded. The dashed line that roughly bisects the Parece Vela Basin is thought to be the extinct backarc spreading axis for the basin. Detailed survey areas for Sites 449 and 450 are shown and DSDP Sites 53 and 54 are located.)

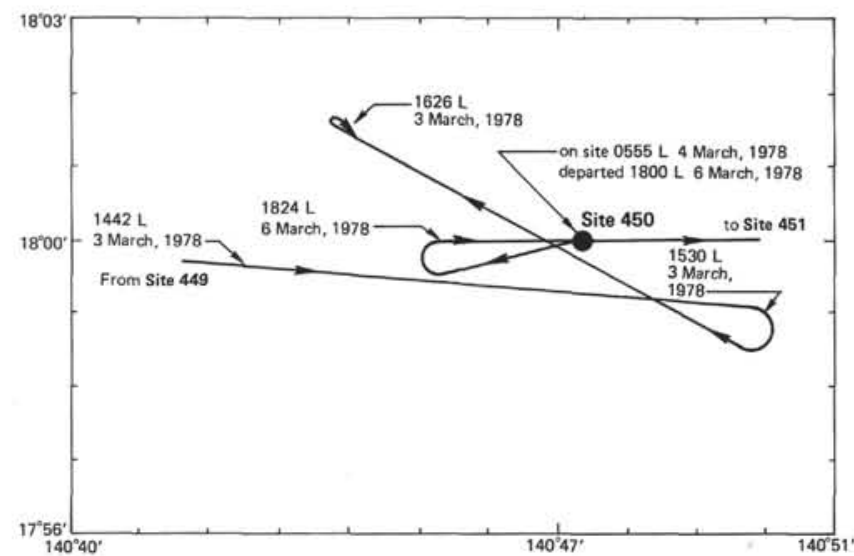

Figure 6. Track of the Glomar Challenger near Site 450 showing details of pre- and postsite surveys. (The solid circle marks the position of the site.)

to match the precision depth recorder (PDR) depth with that previously determined when the Challenger passed the position of minimum sediment thickness over the basement pinnacle. Initial positioning conditions were difficult because of the magnitude and direction of wind, swells, and currents; about 3.5 additional hours were required before the vessel could maintain a heading that would reduce roll to a safe level for handling the drill string. An unexpectedly strong current from the south interacted with the 20 -knot northeast trade winds and three sets of swells. The initial pipe trip was further delayed three-quarters of an hour by difficulties with the pipe racker skate control valve. Hole 450 was spudded in at 0555 hours, 4 March in 4707 meters of water.

Concern for the bottom-hole assembly was generated when hard layers of silicified ash were encountered between 18 and 25 meters sub-bottom. With rotation, however, the bit broke through rather quickly because only thin strata were encountered. Coring operations proceeded smoothly for the remainder of the hole, except for extremely low core recovery through about 60 meters of poorly consolidated ash and tuff beds. No hole problems were experienced.

Core 36 ended in 2 to 3 meters of hard drilling (Table 1). During the attempt to retrieve the inner core barrel, it was found to be stuck in place and the safety-release pin sheared. At about the same time, one of the main motor bearings of the auxiliary hydraulic unit was discovered to be running rough and hot. Running the bearing to complete failure easily could have damaged the motor shaft and ended drilling capabilities. This hydraulic unit powers both the sand-line winch and the power sub; thus it was not feasible to make another wire-line attempt or to rotate the drill pipe until repairs had been made. Because the bearing replacement required much more time than had been budgeted to Site 450 , there was no choice but to retrieve the drill string and proceed to the next site while repairs were in progress.

The inner barrel was no longer stuck when the outer core barrel reached the rig floor. The core recovered consisted of 2.1 meters of basalt and an equal amount of overlying sediment. Thus most of the scientific objectives seemed to have been attained. 
Table 1. Coring summary for Hole 450 .

\begin{tabular}{|c|c|c|c|c|c|c|c|}
\hline $\begin{array}{l}\text { Core } \\
\text { No. }\end{array}$ & $\begin{array}{c}\text { Date } \\
\text { (March, } \\
\text { 1978) }\end{array}$ & $\begin{array}{l}\text { Local } \\
\text { Time } \\
\text { (L) }\end{array}$ & $\begin{array}{l}\text { Depth from } \\
\text { Drill Floor } \\
\text { (m; top-bottom) }\end{array}$ & $\begin{array}{l}\text { Depth below } \\
\text { Sea Floor } \\
\text { (m; top-bottom) }\end{array}$ & $\begin{array}{l}\text { Length } \\
\text { Cored } \\
\text { (m) }\end{array}$ & $\begin{array}{l}\text { Length } \\
\text { Recovered } \\
\text { (m) }\end{array}$ & $\begin{array}{c}\text { Recovery } \\
(\%)\end{array}$ \\
\hline 1 & 4 & 0650 & $4720.0-4727.5$ & $0.0-7.5$ & 7.5 & 7.3 & 97 \\
\hline 2 & 4 & 0800 & $4727.5-4737.0$ & $7.5-17.0$ & 9.5 & 8.5 & 89 \\
\hline 3 & 4 & 0930 & $4737.0-4746.5$ & $17.0-26.5$ & 9.5 & 9.6 & 101 \\
\hline 4 & 4 & 1055 & $4746.5-4756.0$ & $26.5-36.0$ & 9.5 & 8.5 & 87 \\
\hline 5 & 4 & 1220 & $4756.0-4765.0$ & $36.0-45.5$ & 9.5 & 5.5 & 58 \\
\hline 6 & 4 & 1345 & $4765.5-5775.0$ & $45.5-55.5$ & 9.5 & 1.9 & 20 \\
\hline ? & 4 & 1521 & $4775.0-4784.5$ & $55.0-64.5$ & 9.5 & 0.2 & 2 \\
\hline 8 & 4 & 1703 & $4784.5-4794.0$ & $64.5-74.0$ & 9.5 & 2.9 & 30 \\
\hline 9 & 4 & 1830 & $4794.0-4803.5$ & $74.0-83.5$ & 9.5 & $\mathrm{Tr}$ & 0 \\
\hline 10 & 4 & 2008 & $4803.5-4813.0$ & $83.5-93.0$ & 9.5 & 0.0 & 0 \\
\hline 11 & 4 & 2148 & $4813.0-4822.5$ & $93.0-102.5$ & 9.5 & 0.6 & 6 \\
\hline 12 & 4 & 2320 & $4822.5-4832.0$ & $102.5-112.0$ & 9.5 & 3.3 & 35 \\
\hline 13 & 5 & 0052 & $4832.0-4841.5$ & $112.0-121.5$ & 9.5 & 4.3 & 45 \\
\hline 14 & 5 & 0225 & $4841.5-4851.0$ & $121.5-131.0$ & 9.5 & 9.6 & 101 \\
\hline 15 & 5 & 0400 & $4851.0-4860.5$ & $131.0-140.5$ & 9.5 & 7.2 & 76 \\
\hline 16 & 5 & 0525 & $4860.5-4870.0$ & $140.5-150.0$ & 9.5 & 8.1 & 85 \\
\hline 17 & 5 & 0645 & $4870.0-4879.5$ & $150.0-159.5$ & 9.5 & 7.5 & 79 \\
\hline 18 & 5 & 0802 & $4879.5-4889.0$ & $159.5-169.0$ & 9.5 & 7.6 & 80 \\
\hline 19 & 5 & 0924 & $4889.0-4898.5$ & $169.0-178.5$ & 9.5 & 8.7 & 92 \\
\hline 20 & 5 & 1040 & $4898.5-4908.0$ & $178.5-188.0$ & 9.5 & 3.5 & 37 \\
\hline 21 & 5 & 1208 & $4908.0-4917.5$ & $188.0-197.5$ & 9.5 & 8.0 & 84 \\
\hline 22 & 5 & 1340 & $4917.5-4927.0$ & $197.5-207.0$ & 9.5 & 5.8 & 61 \\
\hline 23 & 5 & 1450 & $4927.0-4936.5$ & $207.0-216.5$ & 9.5 & 0.5 & 5 \\
\hline 24 & 5 & 1620 & $4936.5-4946.0$ & $216.5-226.0$ & 9.5 & 4.6 & 48 \\
\hline 25 & 5 & 1750 & $4946.0-4955.5$ & $226.0-235.5$ & 9.5 & 2.6 & 24 \\
\hline 26 & 5 & 1927 & $4955.0-4964.5$ & $235.5-245.0$ & 9.5 & 4.5 & 47 \\
\hline 27 & 5 & 2054 & $4964.5-4974.0$ & $245,0-254.5$ & 9.5 & 2.0 & 21 \\
\hline 28 & 5 & 2230 & $4974.0-4983.5$ & $254.5-264.0$ & 9.5 & 7.7 & 81 \\
\hline 29 & 5 & 2350 & $4984.0-4993.5$ & $264.0-273.5$ & 9.5 & 3.3 & 35 \\
\hline 30 & 6 & 0105 & 4993.5-5003.0 & $273.5-283.0$ & 9.5 & 7.1 & 75 \\
\hline 31 & 6 & 0232 & $5003.0-5012.5$ & $283.0-292.5$ & 9.5 & 7.5 & 80 \\
\hline 32 & 6 & 0355 & $5012.5-5022.0$ & $292.5-302.5$ & 9.5 & 7.0 & 74 \\
\hline 33 & 6 & 0515 & $5022.0-5031.5$ & $302.0-311.5$ & 9.5 & 6.6 & 69 \\
\hline 34 & 6 & 0651 & $5031.5-5041.0$ & $311.5-321.0$ & 9.5 & 2.9 & 30 \\
\hline 35 & 6 & 0840 & $5041,0-5050.5$ & $321.0-330.5$ & 9.5 & 4.2 & 44 \\
\hline 36 & 6 & 1715 & $5050.5-5060.0$ & $330.5-340.0$ & 9.5 & 4.2 & 44 \\
\hline Total & & & & & 340.0 & 183.3 & 53.9 \\
\hline
\end{tabular}

Had the breakdown not occurred, however, additional cores would have been taken to answer important questions about the basalt occurrence. After the contents of Core 36 were studied, revealing evidence of the intrusive nature of the basalt, it was clear that the key scientific objectives had not been reached-neither the age nor the petrology of the basement of Site 450 could be determined.

In retrospect, it is unfortunate that Site 450 had not been located over deeper basement rather than on a basement high. In addition, at the time the site position was established before the cruise, the abundance of sills within the Shikoku Basin (northern extension of the Parece Vela Basin, Leg 58, Klein, Kobayashi, et al., in press) was not yet published. However, shipboard scientists on Leg 59 were aware of Leg 58 results and thus were cognizant of the strong possibility of encountering an intrusive body; perhaps more shipboard latitude for site selection and drilling time would have been desirable in this case.

The string was retrieved by $1754 \mathrm{~L} 6 \mathrm{March}$, and after a short reflection-profile survey was conducted, the vessel headed for Site 451.

\section{SEDIMENTARY LITHOLOGY}

At Site 450, 333 meters of Pleistocene to middle Miocene sediments were drilled and continuously cored down to an intrusive contact with basalt; only 7 meters of basalt were cored before mechanical difficulties necessitated termination of drilling 340 meters below the mudline. Evidence that will be discussed later in this report suggests that this basalt is not basement but is a subsediment pillow basalt intrusion.
The sediments overlying the basalt belong to two lithologically and genetically distinct major units: Unit 1, middle-Miocene to Pleistocene pelagic clays; and Unit 2, middle-Miocene fine vitric tuffs with minor vitric tuffs and rare tuffaceous volcaniclastic conglomerate. Within Units 1 and 2, there are enough distinct and significant variations to merit subdivision into two and three sub-units, respectively (Fig. 7).

Within Unit 1, Sub-unit 1a (26.5 meters thick) consists of upper-Miocene to Pleistocene dark brown pelagic clays in the upper 23.5 meters and dark yellowish brown pelagic clays in the basal 3.0 meters. These clays are homogenous except for scattered mottles, slightly greater indurated sediment (where locally enriched volcanic glass and zeolites prevail), a $3-\mathrm{cm}$ manganese nodule in Core 1 , and a patch of volcanic glass shards presumably from a disintegrated fragment of pumice. Volcanic glass is disseminated throughout the sub-unit in background quantities of $3 \%$ to $10 \%$, with the lower values occurring in Core 1; no indurated lumps occur in Core 1. Also in Core 1, the typical zeolite content is between $2 \%$ and $3 \%$. A smear slide of one of the lumps in Core 2 contains $86 \%$ volcanic glass and $5 \%$ zeolites. Sub-unit 1a is essentially barren of biogenous content, except for a horizon containing siliceous fossils in the uppermost meter of the sediment and ubiquitous phosphatic fish remains in amounts of $1 \%$ to $2 \%$. Amorphous dark brown iron-oxide grains $(2-5 \%)$ and micronodules $(1-2 \%)$ provide the sediment with coloration. The darker mottles are enriched and the lighter mottles impoverished in these constituents.

Sub-unit $1 \mathrm{~b}, 57.0$ meters thick, is a middle-Miocene to upper-Miocene pelagic clay colored dark yellowish brown, dark grayish brown, grayish brown, and dark gray, with minor but significant layers of ash and ashy clay ranging in thickness between 0.3 and $17 \mathrm{~cm}$, averaging about $7 \mathrm{~cm}$. Cumulatively, these layers comprise only about $1.5 \%$ of the total sub-unit thickness; however, disseminated glass is an important constituent of the entire sub-unit, which owes its variegated coloration to varying glass contents that average about $18 \%$ in smear slides. Nannofossils, which are absent in Sub-unit 1a, average about $10 \%$ in Sub-unit 1b. Radiolarians are present in Cores 4 and 5, locally attaining abundances up to $35 \%$ in smear slides.

The contact between Units 1 and 2 was not recovered; it is placed arbitrarily at the top of core of Core 10 between the lowest recovery of pelagic clay (Sample 9,CC) and the uppermost recovery of fine vitric tuff (Sample $10, \mathrm{CC})$. The abundance of fish remains is less than in Sub-unit 1a, occurring only in trace amounts; this down-core reduction is due in part to dilution by the ash constituent.

Sub-unit 2a consists of middle-Miocene fine vitric tuffs with minor vitric tuffs and rare tuffaceous volcaniclastic conglomerate; its 241.0-meter thickness comprises over $70 \%$ of the total section. The glass has been diagenetically altered in varying degrees to clay minerals. Notwithstanding this, the tuff names used for Unit 2 deliberately are not qualified with clayey or clay prefixes to distinguish the primary explosive volcanic provenance of Unit 2 from the terrigenous and authigenic pelagic clays of Unit 1 . 


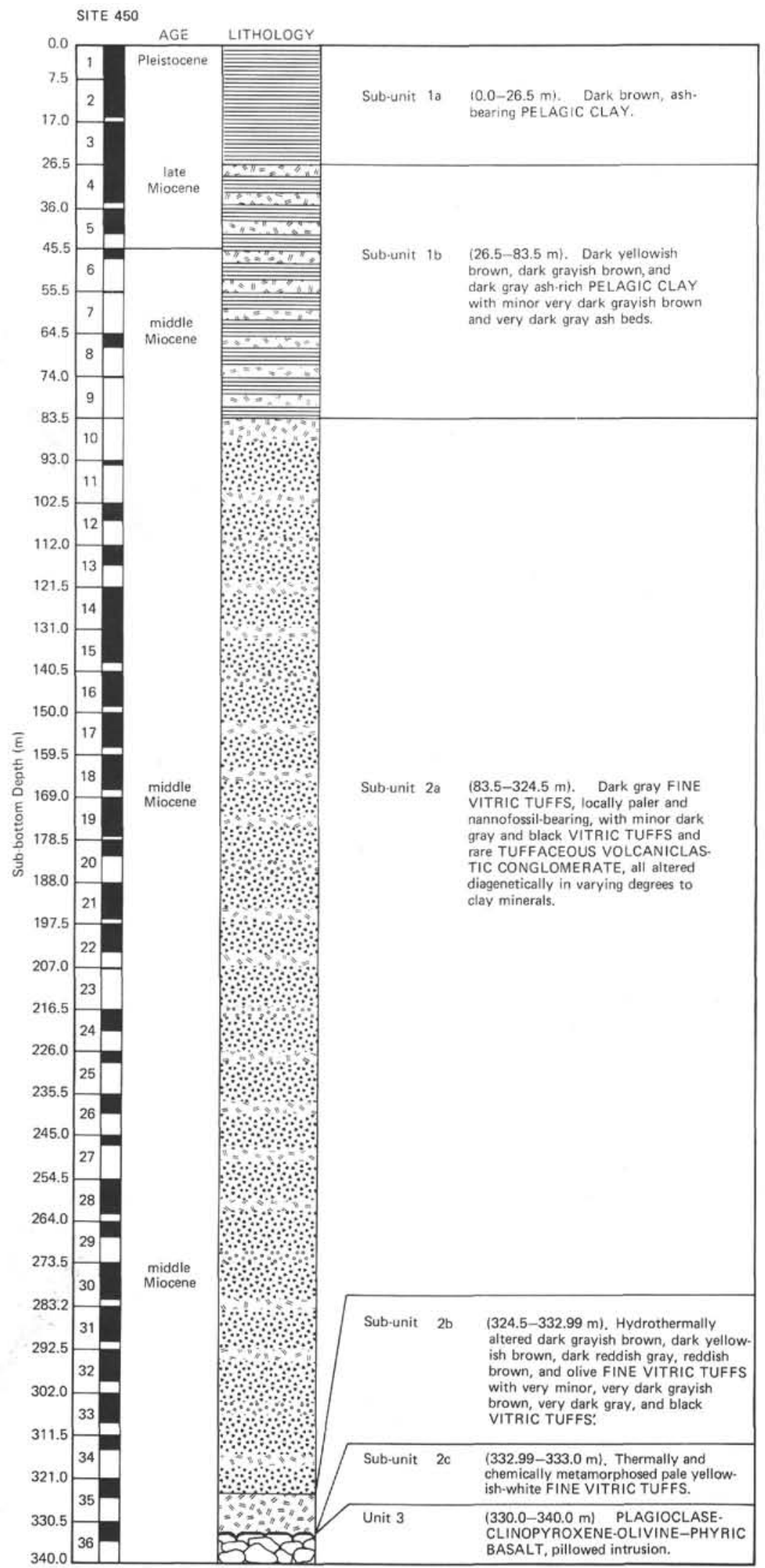

Figure 7. Lithology, age, and core recovery at Site 450 . (The heavier line on pillow tops indicates the top of a pillow-lava unit, which in this case is a subsediment pillowed intrusion. Core recovery is indicated by the solid symbol. Lithologic symbols are summarized in the Introduction to this volume.) 
Fine vitric tuffs that comprise $94 \%$ of the Sub-unit $2 a$ sediments were not homogenized by drilling and coring. These sediments are dark gray, locally paler where richer in calcareous material and darker where richer in coarser ash. Dark gray and black vitric tuff beds, ranging in thickness from $1 \mathrm{~cm}$ in Core 19 to $282 \mathrm{~cm}$ in Core 20 , together make up only $5 \%$ of the total Sub-unit $2 \mathrm{a}$ sediment. Tuffaceous volcaniclastic conglomerate occur as six layers in Cores 12 through 14 and as single beds in Cores 24 and 30 . They have an aggregate thickness of 3.4 meters and constitute $1.5 \%$ of Sub-unit $2 \mathrm{a}$. These coarser vitric and pumiceous layers interrupt the tuffs in the upper 194 meters of the sub-unit, but the basal 47 meters of fine vitric tuff form a homogenous lithology.

Fresh volcanic glass ranges between $5 \%$ and $86 \%$, averaging $38 \%$ in smear slides. The crystal component of the tuffs is minor: feldspar and heavy mineral grains each average only about $1 \%$ in smear slides. Clay minerals average $27 \%$ and are the product of diagenesis of glass. Constant values of interstitial water chlorinity support this impression. Calcium carbonate is a minor but ubiquitous constituent of the tuffs $(0-8 \%$, the results of shipboard carbonate-bomb analyses). Maximum $\mathrm{CaCO}_{3}$ bomb values occur in Core 32 . Recrystallized carbonate grains are present only in the basal 50 meters of Sub-unit $2 a$, increasing from trace amounts in Core 30 to the maximum values of $6 \%$ in Core 31 . Zeolites are present in small amounts $(1-3 \%)$. Micronodules are also disseminated through the sediment in amounts ranging from traces to $3 \%$.

The tuffs display a remarkably diverse suite of sedimentary structures, including parallel and ripple lamination, cross-bedding, load casts, and both normal and reverse grading in conglomerate and vitric tuff beds. Normal and reverse faulting and fractures were also observed. Some of these faults are clearly penecontemporaneous deformations; others may be tectonic (see Chotin, this volume). Faunal activity in the freshly deposited finer tuffs is evidenced by several moderately to intensely bioturbated zones; isolated burrows are even more common. The fine tuffs are massive and featureless only in beds up to 2 meters thick.

Sub-unit $2 b, 8.5$ meters thick, appears identical to Sub-unit 2a lithology, with the exception of hydrothermally induced brownish discoloration of the basal fine vitric tuffs of Unit 2. Also there appears to be an increase in zeolite content up to $20 \%$ in some, but not all, of the smear slides from the sub-unit. The uppermost brownish material is a dark grayish brown fine vitric tuff. From this horizon, and within an interval of 43 $\mathrm{cm}$, the colors pass downward through dark yellowish brown and dark grayish brown to olive-gray, the colors of the sub-unit in its recovered basal 2.75 meters. The mineral paragenesis of this sub-unit is reported in detail in Sartori and Tomadin (this volume).

Sub-unit $2 \mathrm{c}$ is described in detail later in this chapter. It is leached to a pale yellowish white color and consists of $1 \mathrm{~cm}$ of fine vitric tuff forming a baked contact with the uppermost basalt.

Because Site 450 did not reach basement but instead terminated in a pillow basalt that intruded the sedimen- tary sequence, the depositional history of Site 450 recorded in the stratigraphic column begins in the middle Miocene, when the site was already accumulating tuffs derived from volcanism on the West Mariana Ridge to the east. The oldest sediments recovered are in contact with basalt. The basalt is considered to be a very shallow intrusive body that is essentially penecontemporaneous with deposition. The lack of coarse ejectamenta in the Unit 2 tuffs indicates that the site was at some distance from the major volcanic locus of the West Mariana Ridge. The coarsest, sand-sized tuffs appear to have been transported subaqueously as slumps and density flows, which formed turbiditic as well as directional current structures. We assume that the West Mariana Ridge is the source, because the sedimentary wedge thickens to the east. At least in part, the finer-grained ashes probably accumulated as fine laminations from subaerial ash falls over the site. Carbonate nannofossils are a persistent, if minor, component of the Unit 2 tuffs, indicating that the seafloor at Site 450 was above the CCD during the middle Miocene. The low absolute abundance of this biogenous component results from strong dilution by the large influxes of ash.

Volcanic activity diminished quite rapidly in the latest middle Miocene. Contemporaneously, the seafloor at Site 450 subsided below the CCD and began accumulating the pelagic brown clays of Unit 1 . Intermittent pulses of volcanism continued into the late Miocene (as recorded in the deposition of a few thin ashy beds in Sub-unit $1 \mathrm{~b}$ ), but regional volcanism appears to have ceased altogether by the Pleistocene. By this time the seafloor had subsided well below the CCD-the uppermost sediments of Sub-unit 1a contain virtually no carbonate.

\section{BIOSTRATIGRAPHY}

In the one hole drilled at Site 450, 333 meters of sediment overlie basalt. Within the sedimentary succession, pelagic brown clays are present in the uppermost part, grading downward into ash-rich pelagic clay and vitric tuff. Fossil occurrences are restricted to a few levels, with the exception of the calcareous nannoplankton, which are continuously present from Cores 6 to 35 .

In the top of Core 1, a horizon containing diatoms is found associated with lower-Pleistocene radiolarians and rare silicoflagellates and sponge spicules. In Cores 4 and 5, nannoplankton, radiolarians, and rare benthic foraminifers, most of which are arenaceous, are present; the nannoplankton and radiolarians indicate the lower upper Miocene. Below Core 5, sediments are barren of radiolarians. Planktonic foraminifers occur sporadically from Core 6 through Core 30 . The foraminiferal assemblage of Sample 17,CC can be placed in the interval of Blow's Zone N.10 to N.12, which is in good accordance with the nannoplankton data that at this level indicate Zone NN 6 (Discoaster exilis Zone). Planktonic foraminifers present in Section 24-1 indicate that this sample is not older than middle Miocene (probably Zone N.9). Below Core 30, all samples are essentially barren of foraminifers. Between Cores 6 and 35, a continuous sequence of the middle-Miocene calcareous 
nannoplankton Zones NN 0 (D. hamatus Zone) to NN 5 (Sphenolithus heteromorphus Zone) is present, with fair preservation of nannofossils. In Cores 34 and 35 calcareous nannofossils are strongly etched, with only the more solution-resistant species preserved. The lower part of Core 35 as well as Core 36 in the hydrothermally altered sediments above the basalt are both barren of fossils.

\section{Calcareous Nannoplankton}

Cores 1 to $5(0-45.5 \mathrm{~m})$ are barren of calcareous nannoplankton, with the exception of the lowest part of Core 4 and the upper part of Core 5 . Here poorly preserved mixed nannoplankton assemblages of Zones NN 9 (Discoaster hamatus Zone) and NN 10 (D. calcaris Zone, upper Miocene) are present. From Core 6 downward, calcareous nannoplankton are continuously present. The following middle-Miocene zones were identified: NN 9 (D. hamatus Zone) in Core 6 $(45.5-55.0 \mathrm{~m})$, NN 8 (Catinaster coalitus Zone) in Core 7 and the upper part of Core 8 (55.0- $66.5 \mathrm{~m})$, NN 7 (D. kugleri Zone) in the lower part of Core 8 down to Core $12(\sim 66.5-$ $112.0 \mathrm{~m})$, NN 6 (D. exilis Zone) in Core 13 to the upper part of Core $18(112.0-\sim 163.0 \mathrm{~m})$, and NN 5 (Sphenolithus heteromorphus Zone) in the lower part of Core 18 to the upper part of Core $35(\sim 163.0-\sim 324.0 \mathrm{~m})$.

Preservation in this sequence is fairly good, with discoasters only slightly overgrown by calcite, probably owing to the high ash content of the sediment. In the lowest part (Cores 34 and 35), however, the calcareous nannofossils are strongly etched and only the more solution-resistant parts are preserved. The lower part of Core 35 and Core 36 are barren of calcareous nannoplankton.

\section{Foraminifers}

Cores 1 through 3 are barren of foraminifers. Samples from Cores 4 and 5 are either barren or contain only rare arenaceous or rare, poorly preserved, calcareous benthic specimens. Planktonic foraminifers occur sporadically from Cores 6 through 30 . The presence of rare Globorotalia peripheroronda in Section 12-2 and Section 15-3 indicates that these samples date from the early to middle Miocene (Zones N.5-N.13). Sample 17,CC contains $G$. fohsi fohsi (in addition to $G$. peripheroronda), which places this sample within Blow's middle-Miocene Zones N.10-N.12. Section 24-1 still contains Orbulina universa, a species that does not occur below middle-Miocene Zone N.9. The interval from the base of Core 24 to the contact with basalt in Core 36 is nearly barren of foraminifers.

\section{Radiolarians}

Of the 36 cores drilled at Site 450 , three contain radiolarians: Sample 1-1, $57-59 \mathrm{~cm}$ has a meager lowerPleistocene fauna with Stylatractus universus; and Samples 4,CC and 5,CC feature a sparse assemblage belonging to the lower upper Miocene Ommatartus antepenultimus Zone.

\section{Diatoms and Silicoflagellates}

Diatoms occur only in the upper part of Core 1 (Sample 1-1, $\sim 50-60 \mathrm{~cm}$ ) and include Coscinodiscus spp. and fragments of a large Ethmodiscus species. They are associated with lower Pleistocene radiolarians and rare silicoflagellates and sponge spicules.

\section{PALEOENVIRONMENT}

Cores 1 through 3 lack calcareous fossils and probably were deposited below the CCD. Parts of Cores 4 and 5 contain poorly preserved nannofossils and/or benthic (but no planktonic) foraminifers, suggesting deposition below the calcite lysocline. From Core 6 down to the middle of Core 35, nannofossils are continuously present, and relatively diverse planktonic foraminifers occur from the base of Core 6 through Core 17 but are rare and sporadic below Core 17. These data may indicate that the lower portion of the sediment column (Core 6 and below) was deposited somewhat above the CCD. However, extensive diagenesis of volcanic glass to clays and recrystallization of calcite in the lower part of the core suggest that an adverse porewater chemical environment accounted for the rareness of foraminifers below Core 17. Also hydrothermal alteration close to the basalt/sediment contact probably accounts for the etching of nannofossils in Cores 34 and 35 and the absence of fossils in the lower part of Core 35 and in Core 36.

The scarcity of benthic foraminifers at this site precludes their use in precise environmental interpretation.

\section{ACCUMULATION RATES}

The sequential occurrences of four nannofossil zonal boundaries and lower Pleistocene radiolarians allows a measure of sediment accumulation rates at Site 450 (Fig. 8 ). The resulting curve is distinguished by two prominent features: a remarkably constant rate of deposition for the middle Miocene tuffaceous sediments amounting to greater than $50 \mathrm{~m} / \mathrm{m}$.y.; and an abrupt transition to approximately slightly greater than $2 \mathrm{~m} / \mathrm{m}$.y., which takes place toward the end of the middle Miocene. This transition marks the cessation of a predominantly volcanogenic sedimentary regime in this area and the subsequent continuation of undiluted, typical pelagic sedimentation during the remaining time between the Miocene and the Quaternary.

Although no paleontologic boundary is available in the lowest 15 meters above the basalt/sediment contact in Hole 450, the NN 5 assemblage is present to within 9 meters of the contact, and extrapolation of an age of about $17 \mathrm{~m}$.y. for this contact can be made with reasonable confidence, owing to the uniformity of the tuffaceous sediments throughout most of the hole and the surprising linearity of the curve of Figure 8 .

\section{ORGANIC GEOCHEMISTRY}

A single sample was collected from the gas show in Section 3-4 and analyzed by the gas-ghromatographic 


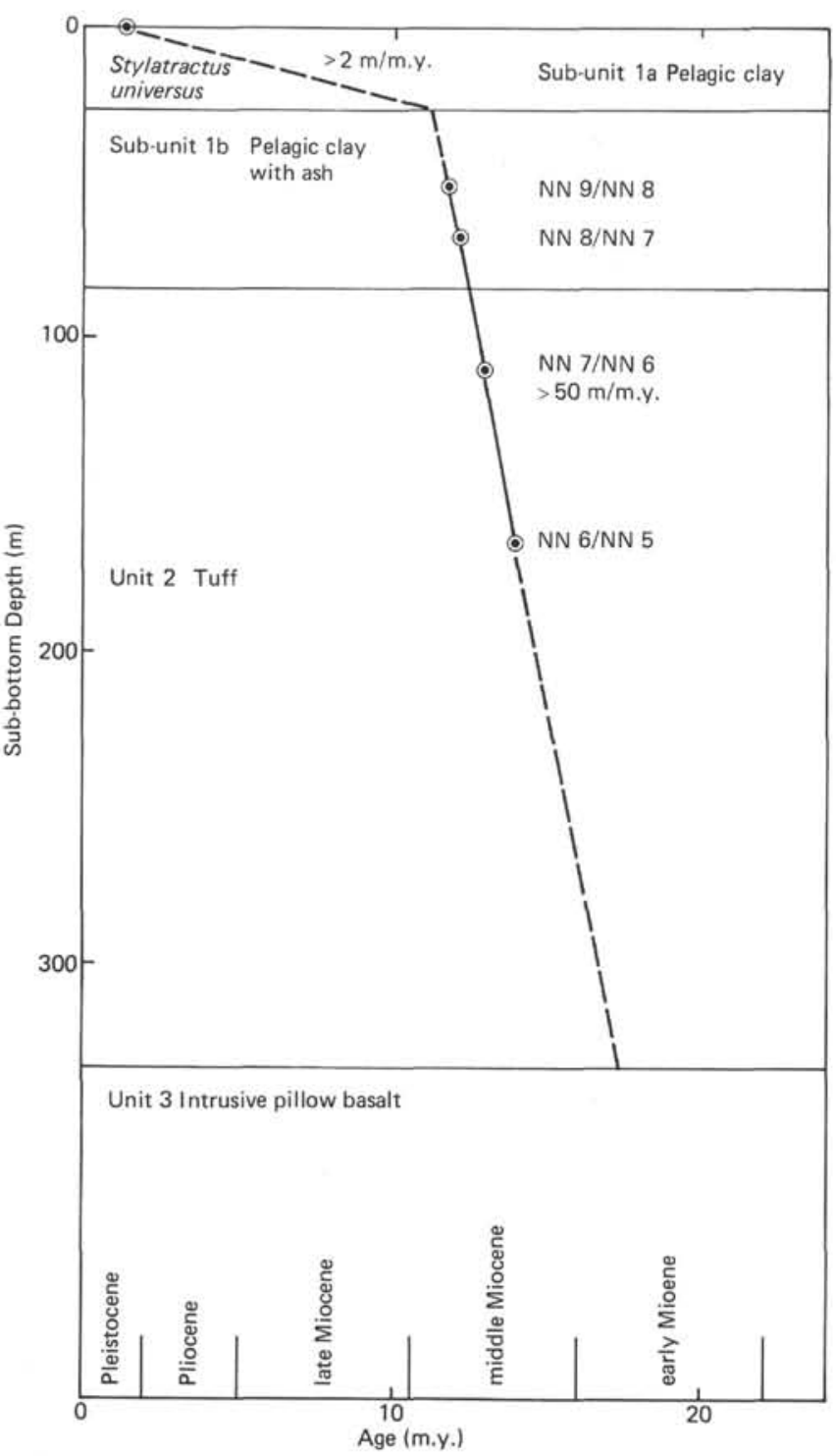

Figure 8. Accumulation rates estimated for the sedimentary sequence of Site 450. (The time-scale is after Schlanger et al. [1976]. The definition of the nannofossil zonal boundaries follows Martini [1971]; the calibration of these zonal boundaries to the time-scale is taken from Martini [1976]. Stylatractus universus is present in the lower-Pleistocene radiolarian fauna found in the upper part of Section 450-1-1. The dashed line represents accumulation rates extrapolated on a basis of lithologic boundaries where paleontologic control is lacking.)

methods outlined in the Introduction (this volume). As with the shows of the other sites, no hydrocarbon gases were detected, but minor amounts of $\mathrm{CO}_{2}$ were present. The lack of hydrocarbon gases is probably because of an absence of appropriate source material.

Analytic methods for organic carbon and nitrogen analyses of the 44 samples investigated are discussed in the Introduction (this volume). The results are given in Table 2 and plotted against depth in Figure 9. Within sedimentary Unit 1 there is a gradual decrease in the organic carbon content of the carbonate-free sediment over the upper 30 meters of recovered cores. This trend is similar to that found at Site 449 and may again be attributed to microbial action in the uppermost horizons
Table 2. Organic carbon and nitrogen contents (after carbonate dissolution).

\begin{tabular}{|c|c|c|c|c|}
\hline $\begin{array}{l}\text { Lithologic } \\
\text { Sub-unit }\end{array}$ & $\begin{array}{c}\text { Sample } \\
\text { (intervals in } \mathrm{cm} \text { ) }\end{array}$ & $\begin{array}{l}\text { Organic } \\
\text { Carbon } \\
\text { (wt. \%) }\end{array}$ & $\begin{array}{c}\text { Nitrogen } \\
\text { (wt. \%) }\end{array}$ & $\begin{array}{c}\mathrm{C}: \mathrm{N} \\
\text { (atomic ratio) }\end{array}$ \\
\hline 1a & $1-1,114-115$ & 0.34 & 0.082 & 4.8 \\
\hline $1 \mathrm{a}$ & $1-3,114-115$ & 0.40 & 0.077 & 6.1 \\
\hline $1 \mathrm{a}$ & $2-1,114-115$ & 0.28 & 0.076 & 4.3 \\
\hline 1a & $2-3,110-111$ & 0.25 & 0.036 & 8.1 \\
\hline la & $3-1,100-101$ & 0.27 & 0.048 & 6.6 \\
\hline 1a & $3-3,100-101$ & 0.31 & 0.046 & 7.9 \\
\hline $1 \mathrm{a}$ & $3-5,107-108$ & 0.19 & 0.058 & 3.8 \\
\hline $1 \mathrm{~b}$ & $4-1,55-56$ & 0.16 & 0.015 & 12.5 \\
\hline $1 \mathrm{~b}$ & $4-3,75-76$ & 0.12 & 0.010 & 14.0 \\
\hline $1 \mathrm{~b}$ & $4-5,124-125$ & 0.16 & 0.010 & 18.7 \\
\hline $1 b$ & $5-1,90-91$ & 0.15 & 0.011 & 16.0 \\
\hline lb & $5-3,90-91$ & 0.11 & 0.010 & 12.9 \\
\hline $1 \mathrm{~b}$ & $8-1,39-40$ & 0.14 & 0.008 & 20.5 \\
\hline $1 \mathrm{~b}$ & $8-2,39-40$ & 0.13 & 0.010 & 15.2 \\
\hline $2 a$ & $11-1,41-42$ & 0.19 & 0.007 & 31.8 \\
\hline $2 \mathrm{a}$ & $12-1,133-134$ & 0.07 & 0.005 & 16.4 \\
\hline $2 a$ & $12-3,2-3$ & 0.08 & 0.005 & 18.7 \\
\hline $2 a$ & $13-1,136-137$ & 0.07 & 0.005 & 16.4 \\
\hline $2 a$ & $13-3,49-50$ & 0.06 & 0.003 & 23.4 \\
\hline $2 a$ & $14-1,69-70$ & 0.07 & 0.005 & 16.4 \\
\hline $2 \mathrm{a}$ & $14-4,96-97$ & 0.08 & 0.003 & 31.2 \\
\hline $2 a$ & $15-2,29-30$ & 0.11 & 0.006 & 21.5 \\
\hline $2 a$ & $15-4,52-53$ & 0.10 & 0.004 & 29.2 \\
\hline $2 a$ & $16-1,115-116$ & 0.11 & 0.003 & 42.9 \\
\hline $2 a$ & $16-4,41-42$ & 0.10 & 0.005 & 23.4 \\
\hline $2 \mathrm{a}$ & $16-6,54-55$ & 0.11 & 0.005 & 25.7 \\
\hline $2 a$ & $17-1,70-71$ & 0.10 & 0.005 & 23.4 \\
\hline $2 a$ & $17-3,70-71$ & 0.22 & 0.010 & 25.7 \\
\hline $2 a$ & $18-2,73-75$ & 0.09 & 0.005 & 21.1 \\
\hline $2 a$ & $20-3,18-21$ & 0.10 & 0.006 & 19.5 \\
\hline $2 \mathrm{a}$ & $21-2,77-79$ & 0.13 & 0.004 & 38.0 \\
\hline $2 \mathrm{a}$ & $21-4,77-79$ & 0.03 & 0.002 & 17.6 \\
\hline $2 \mathrm{a}$ & $22-1,31-34$ & 0.10 & 0.005 & 23.4 \\
\hline $2 a$ & $22-6,14-15$ & 0.06 & 0.004 & 17.6 \\
\hline $2 a$ & $24-1,70-71$ & 0.10 & 0.006 & 19.5 \\
\hline $2 \mathrm{a}$ & $25-1,131-133$ & 0.04 & 0.003 & 15.6 \\
\hline $2 a$ & $26-1,81-83$ & 0.07 & 0.004 & 20.5 \\
\hline $2 \mathrm{a}$ & $27-1,132-134$ & 0.08 & 0.004 & 23.4 \\
\hline $2 a$ & $28-1,26-28$ & 0.07 & 0.007 & 11.7 \\
\hline $2 \mathrm{a}$ & $28-3,64-66$ & 0.05 & 0.003 & 19.5 \\
\hline $2 a$ & $29-2,102-104$ & 0.06 & 0.005 & 14.0 \\
\hline $2 a$ & $30-1,93-95$ & 0.14 & 0.009 & 18.2 \\
\hline $2 \mathrm{a}$ & $32-1,75-77$ & 0.09 & 0.003 & 35.1 \\
\hline $2 \mathrm{a}$ & $34-1,20-21$ & 0.12 & 0.004 & 35.1 \\
\hline
\end{tabular}

of sediment. Below this top 30 meters, the organic carbon content of the carbonate-free sediments remains approximately constant at around $0.1 \mathrm{wt}$. $\%$. The nitrogen content also appears to decrease over the uppermost 30 meters of the sequence to values less than 0.01 wt. $\%$ and remains virtually constant with depth in the vitric tuff sequence of Unit 2 . It is possible that the initial decrease in nitrogen content within Unit 1 reflects the activity of nitrogen-fixing bacteria, which play an important role in many sedimentary environments by enhancing cyclization of nitrogen within the aquatic food web. The sharp drop in nitrogen content between Section 3-5 and Section 4-1 resembles that found at Site 449 and is also inexplicable, being independent of lithologic change. The C:N ratio increases from about 5 to 15 in the upper 30 meters of the sediments, resembling the 


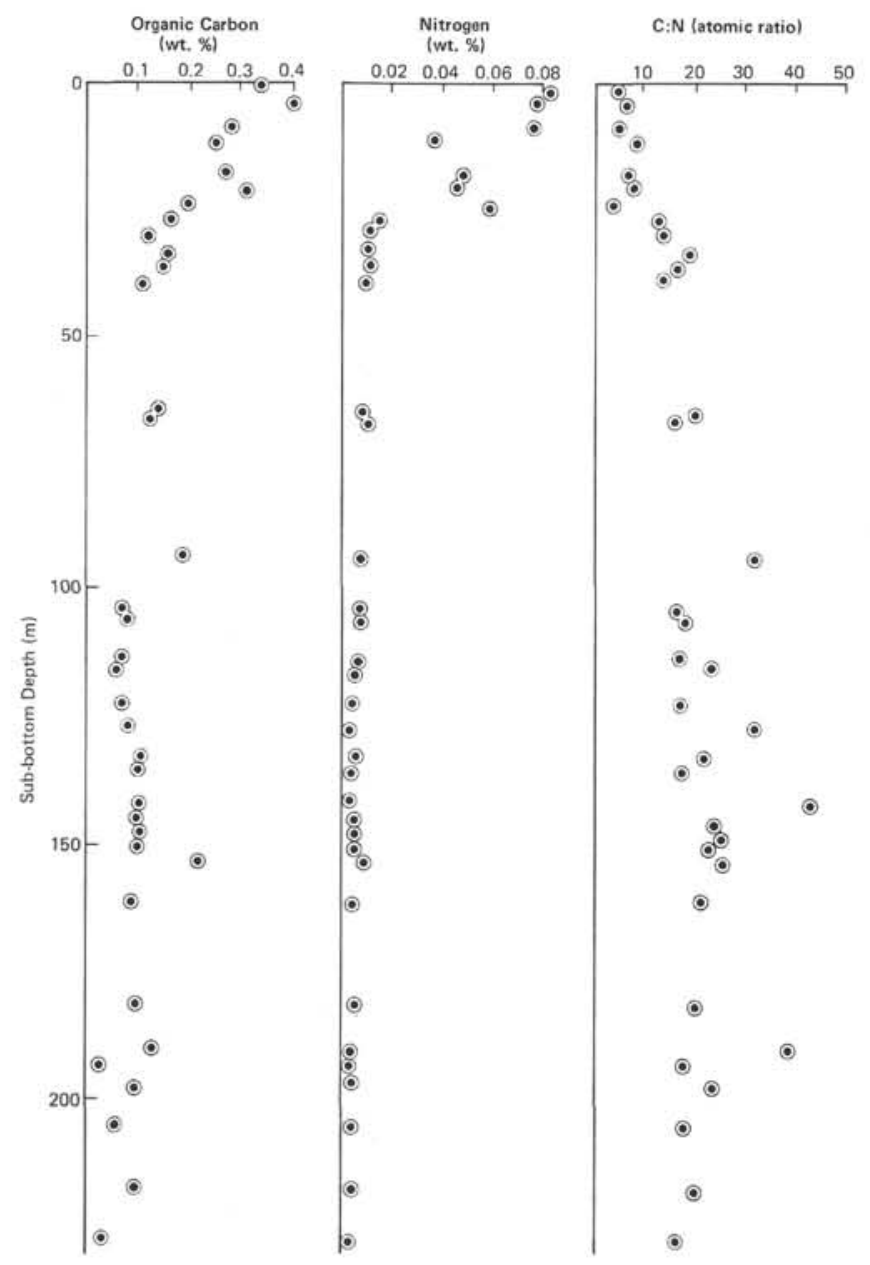

Figure 9. Results of organic carbon and nitrogen analyses plotted versus sub-bottom depth in meters.

pattern observed at Site 449. This result seems to suggest that nitrogen-containing compounds are removed or altered more rapidly than, or preferentially to, carbon compounds. In the vitric tuff sequence of Unit $2 \mathrm{a}$ the $\mathrm{C}: \mathrm{N}$ ratios are erratic, reflecting the inherent inaccuracies in the measurement of the extremely low amounts of nitrogen present.

Methods of Rock Eval analyses are given in the Introduction (this volume), and the results are summarized in Table 3. In Unit 1 the $S_{2}$ response matches that found for clay-rich lithologies at Sites 447 and 449 and may be attributed to the same unidentified phenomenon. The variation among Sites 447, 449, 450 in the results for the vitric tuffs probably stems from the differences in the extent of their alteration to clays.

\section{INORGANIC GEOCHEMISTRY OF INTERSTITIAL WATER}

Interstitial-water analyses were conducted on eight samples (Sections 1-1, 5-2, 12-2, 16-3, 20-1, 24-3, 28-4 and 32-3) from Hole 450. The data obtained from these analyses are plotted against depth in Figure 10. The major feature of this site was the concomittant decrease in $\mathrm{Mg}^{2+}$ content and increase in $\mathrm{Ca}^{2+}$ content with depth. This phenomenon, previously observed at several DSDP sites, is explicable as a result of diagenetic changes in
Table 3. Qualitative estimate of the relative amounts of free hydrocarbons, bound hydrocarbons, and $\mathrm{CO}_{2}$ from kerogen (and carbonate-rich sediments) based upon sizes of $S_{1}, S_{2}$, and $S_{3}$ peaks, respectively, from Rock Eval analyses.

\begin{tabular}{|c|c|c|c|c|}
\hline $\begin{array}{c}\text { Lithologic } \\
\text { Unit }\end{array}$ & $\begin{array}{l}\text { No. of } \\
\text { Samples }\end{array}$ & $\begin{array}{c}\text { Free } \\
\text { Hydrocarbon } \\
\left(S_{1}\right)\end{array}$ & $\begin{array}{c}\text { Bound } \\
\text { Hydrocarbon } \\
\left(S_{2}\right)\end{array}$ & $\begin{array}{c}\mathrm{CO}_{2} \text { from } \\
\text { Kerogen } \\
\left(S_{3}\right)\end{array}$ \\
\hline 1 & 14 & $-1+$ & $++1+++$ & - \\
\hline 2 & 30 & $-1+$ & $-1+$ & - \\
\hline
\end{tabular}

Note: $-=$ undetectable, $-/+=$ undetectable to minor, and $++1+++=$ moderate to major relative amounts.

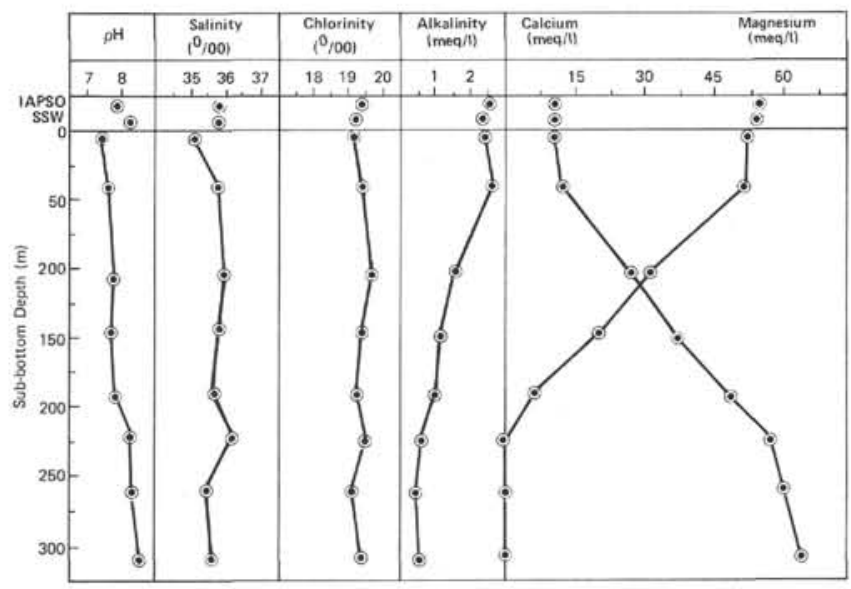

Figure 10. Results of analyses of interstitial water samples plotted versus sub-bottom depth in meters. (IAPSO and standard and surface sea-water sample analyses are shown for comparison.)

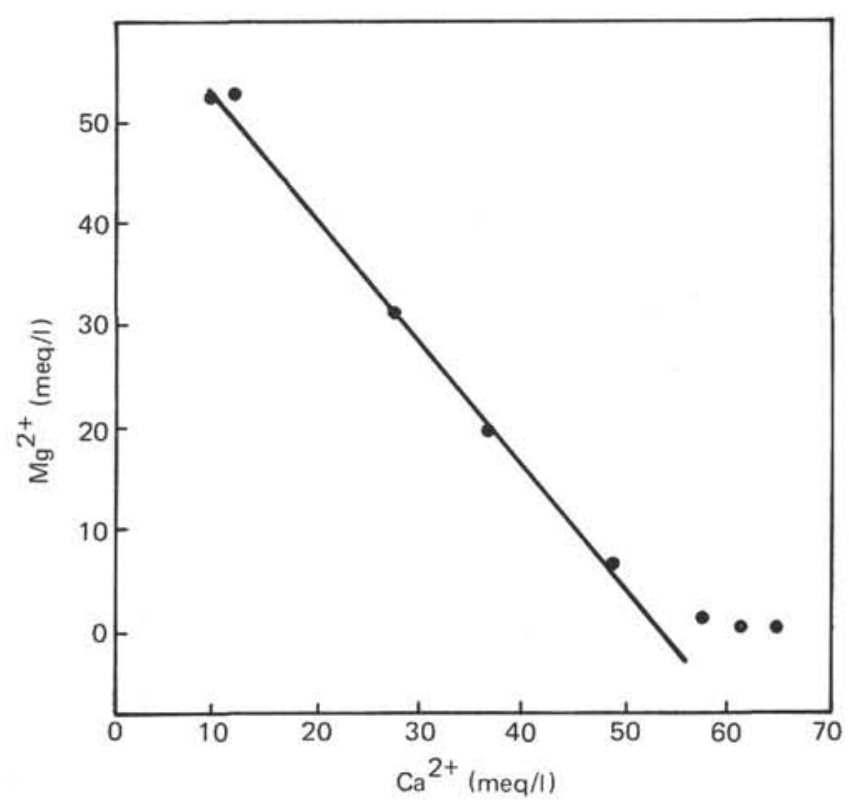

Figure 11. Milliequivalents of $\mathrm{Ca}^{2}+$ per liter versus milliequivalents of $\mathrm{Mg}^{2+}$ per liter.

clay mineralogy where $\mathrm{Mg}^{2+}$ replaces $\mathrm{Ca}^{2+}$, thereby removing $\mathrm{Mg}^{2+}$ from and contributing $\mathrm{Ca}^{2+}$ to the interstitial water. It is also possible, however, that lowtemperature reaction of basaltic glass with sea water 
may have contributed to these changes because $\mathrm{Mg}$-rich clays are formed during basalt glass alteration and $\mathrm{Ca}$ is leached from the glass. It should be noted, however, that this reaction requires formation of clays, not simple hydration of the glass that would create an opposite $\mathrm{Mg}^{2+}$ effect (Thompson, 1973). In addition, the devitrification of volcanic glass releases $\mathrm{Ca}^{2+}$ to the pore waters. The $\mathrm{Ca}^{2+}$ and $\mathrm{Mg}^{2+}$ data show a linear correlation (Fig. 11) to a depth of 225 meters with a $\triangle \mathrm{Ca}^{2+} / \triangle \mathrm{Mg}^{2+}$ ratio of about 0.8 . With increasing depth the $p \mathrm{H}$ increases, whereas the alkalinity declines (Fig. 10), suggesting that with increasing depth the interstitial water is gradually becoming saturated with calcite. This phenomenon will also lead to an increase in $\mathrm{Ca}^{2+}$ content. The salinity and chlorinity show only minor fluctuations with depth.

\section{IGNEOUS PETROGRAPHY}

After drilling through 333.0 meters of pelagic clays and underlying tuffs, 1.7 meters of basalt were recovered from the last core (Core 36 ), which penetrated to 340.0 meters sub-bottom.

The contact relations of that basalt appear to be intrusive: An aureole ( $8.5 \mathrm{~m}$ thick) of relatively lowtemperature hydrothermal alteration exists above this igneous body, where the unaffected monotonous gray tuffs of Sub-unit $2 \mathrm{a}$ become brown and contain zeoliterich layers in Sub-unit $2 \mathrm{~b}$. At least $1 \mathrm{~cm}$ of the tuff con- tact is baked and leached to form the pale yellowish white tuff of Sub-unit $2 \mathrm{c}$ and probably represents the only part of the host rock greatly affected by thermal and chemical metamorphism. The immediate contact itself has a very thin $(0.1 \mathrm{~mm})$, black, glass rim that is ruptured by 0.2 to 0.5 -mm-diameter vents from which tiny cauliflower-shaped jets of glass (1-3 mm long) are injected into the baked sediment (Fig. 12). Several of these features decorate a 4-cm-long preserved contact, definitely requiring an intrusive relationship with overlying tuffs. The cauliflower-shaped jets of glass have been altered to dark blackish green and brownish black patches; below the thin, black, glass rim occurs a transition through about 2 to $5 \mathrm{~mm}$ of black glass and variolites into a pale brownish gray, solid variolitic zone roughly 5 to $10 \mathrm{~mm}$ thick.

The 1.7 meters of basalt recovered from this site contain numerous variolitic or glassy zones, many with high dip angles, suggesting that this basalt forms a pillowed eruptive unit. Thus we conclude that basalts intruded into relatively fluid, unconsolidated ashes that were pushed aside, allowing pillow formation mechanisms to operate below the sea-water/sediment interface. Thereby a subsediment pillow basalt was created.

These basalts are dark- to medium-gray and have glassy, variolitic, or fine-grained intersertal textures. Phenocrysts and large glomerocrysts $(1-5 \mathrm{~mm})$ of plagioclase, clinopyroxene, and occasional reddish

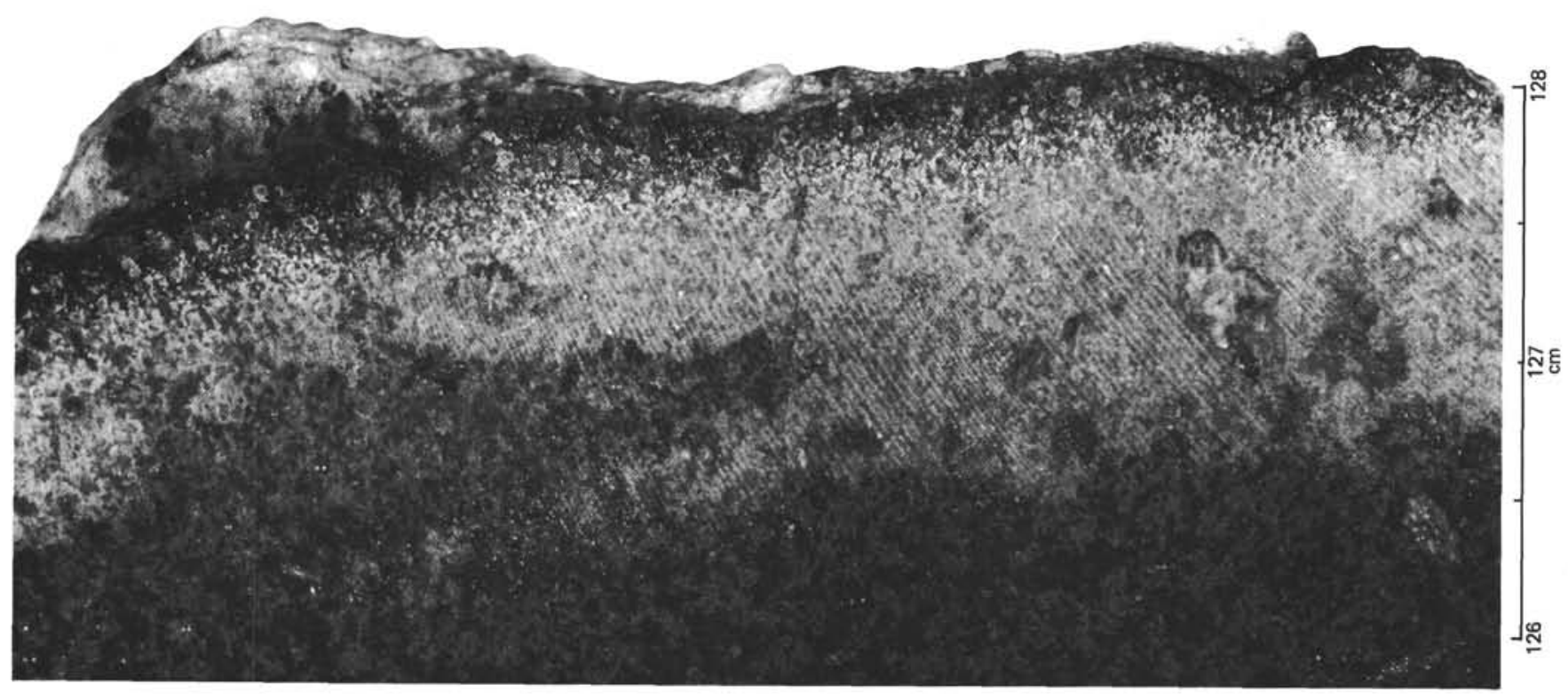

Figure 12. Contact of basalt and sediments. (Baked contact of hydrothermally altered and leached tuffs with chilled glassy margin of the uppermost pillow basalt. The leached tuff is white. The thin black glass rim can be seen clearly on the upper right margin. Cauliflower-shaped intrusions of this glass into the leached tuff are best seen along the upper left margin. Below the black glass is a zone with a variolitic texture about $1 \mathrm{~cm}$ thick that grades into hyalopilitic textures at the base of the photograph.) 
brown smectite pseudomorphs of olivine $(0.5-2 \mathrm{~mm})$ are common. Rare vesicles (1-2 $\mathrm{mm}$ diameter) are infilled with calcite, zeolites, or green smectite. Small veins $(0.2-1 \mathrm{~mm})$ of this secondary mineral assemblage are also common.

In thin section, basalts from Site 450 contain 7 to $17 \%$ phenocrysts and $>80 \%$ groundmass that displays spherulitic or hyalopilitic quench textures. Phenocrysts of plagioclase are common (90-95\% phenocrysts), 0.5 to $6 \mathrm{~mm}$ in size, and contain numerous glass inclusions. Core compositions range from $\mathrm{An}_{80}$ to $\mathrm{An}_{60}$ and show relatively little zonation. A few crystals are partially replaced by calcite or zeolite. Clinopyroxene and olivine phenocrysts are less common (5-10\%); the olivines are now completely pseudomorphed by iddingsite, clays, and zeolites. These crystals are from 0.2 to 0.5 $\mathrm{mm}$ in size and are characteristically skeletal or glomerophyric with plagioclase.

The groundmass is composed predominantly of devitrified glass with flow-aligned microlites of plagioclase. Subophitic clots of clinopyroxene are found in more crystalline areas. Approximately $5 \%$ to $10 \%$ of the devitrified glass has altered to green smectite and felted zeolites. Secondary calcite, smectites, and zeolites infill the rare vesicles $(0.5 \mathrm{~mm}$ in diameter $)$ and form thin veins.

The basalts recovered from Site 450 probably do not represent true oceanic basaltic basement of the eastern side of the Parece Vela Basin for several reasons: Seismic reflection profiles indicate that this feature is relatively small (less than $1 \mathrm{~km}$ across), and it is doubtful that such narrow structural blocks exist. The profiles indicate that basement is significantly deeper nearby ( $>$ $200 \mathrm{~m}$ ). Finally, contact relations show that the basalt intruded a shallow level and into unconsolidated ash.

Three possible interpretations of these relationships exist: First, the basalt intrusion may be associated with seamount-type volcanism superimposed on the basin. Second, the basalt intrusion may be associated with island arc-type volcanism behind the arc proper, and if so, may be somewhat alkalic. And third, the basalt intrusion may represent a late stage of basement formation; if the influx of volcanic debris from the east is exceedingly rapid, 100 meters may accumulate in less than a million years, and the basalt magmas may find themselves inundated before the final stage of spreadingcenter magmatic activity. If this is the case, then the age of the basalt is only slightly younger than the basement.

Except for the presence of clinopyroxene, the absence of spinel microphenocrysts, and a generally greater intensity of low-temperature alteration, however, these basalts are petrographically similar to those recovered from the basement of the western Parece Vela Basin (Site 449), both of which resemble typical Layer-2 basalt.

Site 54 (Leg 6, situated $125 \mathrm{~km}$ southwest of Site 450) recovered analogous plagioclase-olivine-phyric basalts at a depth of 292 meters sub-bottom below a lower- to middle Miocene calcareous ash sequence. Unfortunately the sediment/basalt contact was not completely recovered at this site. At Site $53(44.5 \mathrm{~km}$ east of Site
450), however, fragments of basalt and andesite were encountered at a sub-bottom depth of 195 meters. The overlying sediments (upper Oligocene to lower Miocene), limestones, tuffs, and tuffaceous volcaniclastic conglomerates show evidence of thermal metamorphism, and these volcanic units were interpreted as either dikes or shallow sills (Fischer, Heezen, et al., 1971) on this evidence.

\section{METAMORPHIC PETROGRAPHY}

The tuffaceous sediments that overlie the basalts at 333.0 meters sub-bottom have been distinctly altered, presumably by relatively low-temperature hydrothermal alteration. A brownish colored aureole about 8.5 meters thick covers the igneous contact. Sedimentary constituents, structures, and textures do not change across the boundary from unaffected homogenous gray tuff to altered reddish brown tuff. Colors change from grays and greenish grays $(5 \mathrm{Y} 2 / 1,5 \mathrm{Y} 4 / 1,5 \mathrm{GY} 3 / 2)$ above 324.5 meters to browns (10YR 4/2, 10YR $3 / 4$ and 5YR $4 / 2$ ) below that level; the tuffs are slightly mottled to evenly colored within $15 \mathrm{~cm}$ from the contact. Mineralogic changes occur with the appearance of zeoliterich zones (with up to $20 \%$ zeolites at $324.9 \mathrm{~m}$ subbottom), the appearance of monoclinic alkali feldspars in the last 1.5 meters, and $5 \%$ clinoptilolite and phillipsite in the last 0.2 meters of sediments collected just above the basalts (see Sartori, this volume).

The last $15 \mathrm{~cm}$ of tuff recovered immediately above the contact consist of an interlayered complex of brown (7.5YR 4/2) and dark gray (5YR 3/1) tuffs. The dark gray tuffs are interpreted as a thermally metamorphosed equivalent of the hydrothermally altered brown tuffs. Small black blebs and streaks probably are remobilized and concentrated manganese. The contacts between these two lithologies are irregular and sharp.

The immediate contact consists of a $1-\mathrm{cm}$ pale yellowish white, baked and leached zone in the tuffs and a chilled glassy margin in the basalts described earlier. Probably only this zone has undergone the effect of high-temperature reaction with fluids. No significant amount of iron appears to be left in this rock, and it further appears to be fused to the glassy margin of the basalts. Both in pillow interstices and within pillows themselves small metamorphosed inclusions of tuff occur (see Hajash, this volume).

\section{PALEOMAGNETISM}

Twenty-six samples were collected from the sediments of Hole 450. Table 4 summarizes the natural remanent magnetization (NRM) results. The mean inclination at this site, based upon the NRM results, was found to be $20.2^{\circ}$ and the mean latitude $10.6^{\circ}$ (standard deviation $=14.6$ ). The present latitude at this site is $18^{\circ}$, thus this portion of the Philippine Sea may have undergone a northward motion of at least $8^{\circ}$ since the middle Miocene.

Roughly half of the inclinations at this site are positive, and half are negative. Previously published polarity studies of the middle Miocene indicate a roughly equal division of the normal and reversed polarity 
Table 4. Paleomagnetic declination, inclination, and magnetic intensity of samples from Hole 450 sedimentary rocks.

\begin{tabular}{crrr}
\hline $\begin{array}{c}\text { Sample } \\
\text { (core-section, depth } \\
\text { of interval in cm) }\end{array}$ & $\begin{array}{c}\text { Declination } \\
\left({ }^{\circ}\right)\end{array}$ & $\begin{array}{c}\text { Inclination } \\
\left({ }^{\circ}\right)\end{array}$ & $\begin{array}{c}\text { Intensity } \\
\left(\mathrm{emu} / \mathrm{cm}^{3}\right)\end{array}$ \\
\hline $17-1,18$ & 155.67 & -27.77 & $0.4181 \times 10^{-3}$ \\
$17-2,104$ & 335.16 & 14.03 & $0.7463 \times 10^{-3}$ \\
$17-3,86$ & 189.52 & -1.62 & $0.3210 \times 10^{-4}$ \\
$18-1,30$ & 68.00 & -39.60 & $0.1000 \times 10^{-2}$ \\
$18-2,75$ & 170.00 & -62.30 & $0.5990 \times 10^{-3}$ \\
$18-4,121$ & 332.46 & -40.18 & $0.6874 \times 10^{-4}$ \\
$19-1,13$ & 111.70 & 3.40 & $0.7410 \times 10^{-2}$ \\
$19-3,86$ & 169.50 & -25.30 & $0.8300 \times 10^{-2}$ \\
$19-4,33$ & 250.50 & -16.10 & $0.5040 \times 10^{-2}$ \\
$19-5,49$ & 269.40 & 13.00 & $0.1580 \times 10^{-2}$ \\
$21-1,32$ & 310.70 & -12.33 & $0.1493 \times 10^{-2}$ \\
$21-2,52$ & 209.86 & -1.71 & $0.8553 \times 10^{-4}$ \\
$21-3,55$ & 233.47 & 25.14 & $0.3686 \times 10^{-3}$ \\
$21-5,61$ & 335.18 & -12.36 & $0.1588 \times 10^{-3}$ \\
$23-1,13$ & 131.21 & 21.11 & $0.5683 \times 10^{-3}$ \\
$25-1,26$ & 190.65 & -45.99 & $0.1457 \times 10^{-3}$ \\
$25-2,76$ & 284.76 & 44.60 & $0.2027 \times 10^{-3}$ \\
$26-1,65$ & 14.98 & -6.55 & $0.1805 \times 10^{-3}$ \\
$26-3,101$ & 167.65 & 8.55 & $0.1500 \times 10^{-3}$ \\
$29-1,26$ & 3.26 & 22.62 & $0.5283 \times 10^{-3}$ \\
$31-4,82$ & 212.46 & -28.92 & $0.2446 \times 10^{-3}$ \\
$32-7,4$ & 170.97 & -6.38 & $0.2514 \times 10^{-3}$ \\
$33-2,54$ & 180.03 & 0.47 & $0.2208 \times 10^{-3}$ \\
$35-1,54$ & 180.03 & 0.47 & $0.2208 \times 10^{-3}$ \\
$35-2,133$ & 17.74 & 16.37 & $0.4814 \times 10^{-3}$ \\
$35-3,92$ & 195.54 & 42.08 & $0.2995 \times 10^{-3}$ \\
\hline & & & \\
\hline
\end{tabular}

in this interval. Eight reversed-polarity zones should be present in this interval (nannofossil Zone NN 5), with several brief normal polarity events also present (F. Theyer, personal communication). Paleomagnetic results from this site are consistent with this polarity pattern, suggesting the presence of several reversedpolarity zones. The normal criteria (minimum of two samples per zone) for delineating polarity intervals, however, could not be met, because most of the cores from this hole were too fragmented or too disturbed by drilling to enable us to be certain of the vertical orientation. In summary, the shipboard paleomagnetic results from this site, although limited, are clearly consistent with other Cenozoic magnetic polarity studies.

\section{PHYSICAL PROPERTIES}

Physical properties measured on the sediments and one sample of basalt recovered from Hole 450 include sonic velocity (horizontal and vertical), wet-bulk density, water content, porosity, and acoustic impedance. Recovery at the site was good, and physical properties were measured on almost every core down to the basalt (Core 36 ). Methods and procedures are briefly summarized in the Introduction (this volume). Results are listed in Table 5 and are shown graphically in Figure 13.

Physical properties of the sediments overlying the basalt correlate well with the two lithologic units recognized in Hole 449. In the predominantly pelagic clays of Unit 1 , between the seafloor and 83.5 meters subbottom, sonic velocities range from 1.49 to $1.58 \mathrm{~km} / \mathrm{s}$, averaging $1.54 \mathrm{~km} / \mathrm{s}$. In the vitric tuffs of Unit 2 below 83.5 meters sub-bottom, sonic velocities range from 1.7 to more than $2.1 \mathrm{~km} / \mathrm{s}$, generally increasing with depth. The velocity of the lowermost indurated beds overlying the basalt almost reaches $2.2 \mathrm{~km} / \mathrm{s}$. Anisotropy appears to be present, with horizontal velocities consistently higher than vertical velocities. The velocity of the basalt recovered from the bottom of the hole is $5.2 \mathrm{~km} / \mathrm{s}$ and is comparable to basalt velocities measured at Hole 447A.

Densities in the semiconsolidated vitric tuff sequence, between 83.5 and 333.0 meters sub-bottom, range from 1.45 to $1.68 \mathrm{~g} / \mathrm{cm}^{3}$ without any significant correlation with depth. The density of the basalt sample, recovered at 333.53 meters sub-bottom depth, is $2.81 \mathrm{~g} / \mathrm{cm}^{3}$. Water content of the vitric tuff, ranges from $49 \%$ to $29 \%$ and seems to decrease slightly with depth. Porosities range from $60.0 \%$ to $72.0 \%$, with no apparent correlation with depth. Acoustic impedance of the vitric tuff generally increases with depth and ranges from 2.69 to $3.33 \times 10^{5} \mathrm{~g} /\left(\mathrm{cm}^{2} \mathrm{~s}\right)$. Acoustic impedance of the basalt is $14.67 \times 10^{5} \mathrm{~g} /\left(\mathrm{cm}^{2} \mathrm{~s}\right)$.

\section{GEOPHYSICS}

Acoustically well-stratified sediments attain a considerable thickness on the eastern side of the Parece Vela Basin, in contrast to the western side. Water depths range from around $6 \mathrm{~km}$ in the rougher and deeper part of the basin near and in the IPOD Trough to about $4 \mathrm{~km}$ in the smoother and shallower part of the basin adjacent to the West Mariana Ridge. The rough basement topography is progressively buried eastward below the thick sedimentary wedge apparently derived from the West Mariana Ridge. Site 450 is located approximately $150 \mathrm{~km}$ east of the IPOD Trough and $250 \mathrm{~km}$ west of the West Mariana Ridge at the distal end of the sedimentary apron of the ridge.

Discussing the crustal structure of the Philippine Sea, Murauchi et al. (1968) describe the results from the reversed refraction line shot in the eastern Parece Vela Basin. A relatively thick sedimentary veneer $(0.63-\mathrm{km}$ thick, with a velocity of $2.3 \mathrm{~km} / \mathrm{s}$ ) is reported to be underlain by a $1.6-\mathrm{km}$-thick, $5.0-\mathrm{km} / \mathrm{s}$ layer, in turn underlain by a $4.9-\mathrm{km}$-thick, $6.8-\mathrm{km} / \mathrm{s}$ Layer 3 .

As we approached Site 450 from the west, the reflection profile recorded on board the Challenger (Fig. 14) so closely resembled the L-DGO site-survey multichannel monitor profile that these data were able to be used for vessel navigation. Proximity to the site was definitely established by comparing the two data sets. As the actual site was crossed, however, it became immediately apparent that precise positioning of the ship over the crest of the reflection hyperbola defining the drilling target was essential in order to avoid timeconsuming, deep penetration of the thick sedimentary sequence on either side of the drilling target (in this case, the source generator of the reflection hyperbola). Moreover, although nearby piercement structures in the vicinity of the site obviously disturbed and deformed the entire sediment column almost to the surface (Fig. 14), no indication of the intrusive nature of the source of the reflection hyperbola at Site 450 was discerned in the 
Table 5. Physical properties of sedimentary and igneous rocks from Hole 450.

\begin{tabular}{|c|c|c|c|c|c|c|c|c|c|c|c|}
\hline \multirow{3}{*}{$\begin{array}{c}\text { Sample } \\
\text { (hole-core-section) }\end{array}$} & \multirow{3}{*}{$\begin{array}{l}\text { Sub-bottom } \\
\text { Depth } \\
\text { (m) }\end{array}$} & & & & \multicolumn{3}{|c|}{ Wet-Bulk Density } & \multirow{3}{*}{$\begin{array}{l}\text { Water } \\
\text { Content } \\
(\%)\end{array}$} & \multirow{3}{*}{$\begin{array}{c}\text { Porosity } \\
(\%)\end{array}$} & \multirow{3}{*}{$\begin{array}{l}\text { Calculated } \\
\text { Grain } \\
\text { Density } \\
\left(\mathrm{g} / \mathrm{cm}^{3}\right)\end{array}$} & \multirow{3}{*}{$\begin{array}{c}\text { Acoustic } \\
\text { Impedance } \\
{\left[\times 10^{5} \mathrm{~g} /\left(\mathrm{cm}^{2} \mathrm{~s}\right)\right]}\end{array}$} \\
\hline & & Sor & Veloc & & Gravimetric & $\begin{array}{l}\text { Continuous } \\
\text { GRAPE } \\
\text { (section } \\
\text { averages) }\end{array}$ & $\begin{array}{l}\text { Special } \\
\text { 2-min } \\
\text { GRAPE }\end{array}$ & & & & \\
\hline & & Horizontal & & Vertical & $\left(\mathrm{g} / \mathrm{cm}^{3}\right)$ & $\left(\mathrm{g} / \mathrm{cm}^{3}\right)^{\mathrm{b}}$ & $\left(\mathrm{g} / \mathrm{cm}^{3}\right)^{\mathrm{b}}$ & & & & \\
\hline $450-1-1$ & 0.75 & - & - & - & - & 1.25 & - & - & - & - & - \\
\hline $450-1-2$ & 2.25 & - & - & - & - & 1.30 & - & - & - & - & - \\
\hline $450-1-2$ & 2.53 & 1.495 & - & - & - & - & - & - & - & - & - \\
\hline $450-1-3$ & 3.75 & $\overline{0}$ & - & - & - & 1.26 & - & - & - & - & - \\
\hline $450-1-3$ & 4.08 & 1.512 & - & - & - & - & - & - & - & - & - \\
\hline $450-1-4$ & 5.25 & - & - & - & - & 1.27 & - & - & - & - & - \\
\hline $450-1-4$ & 5.97 & - & - & - & - & - & - & 68.48 & - & - & - \\
\hline $450-2-1$ & 8.25 & - & - & - & - & 1.29 & - & - & - & - & - \\
\hline $450-2-3$ & 11.25 & - & - & - & - & 1.34 & - & - & - & - & - \\
\hline $450-2-4$ & 12.75 & - & - & - & - & 1.33 & - & - & - & - & - \\
\hline $450-2-6$ & 15.23 & 1.539 & - & - & - & - & - & - & - & - & - \\
\hline $450-3-1$ & 17.75 & - & - & - & - & 1.26 & - & - & - & - & - \\
\hline $450-3-3$ & 20.75 & - & - & - & - & 1.25 & - & - & - & - & - \\
\hline $450-3-4$ & 22.96 & 1.543 & - & - & - & - & - & - & - & - & - \\
\hline $450-3-5$ & 23.75 & - & - & - & - & 1.40 & - & - & - & - & - \\
\hline $450-4-1$ & 27.25 & - & - & - & - & 1.48 & - & - & - & - & - \\
\hline $450-4-4$ & 31.75 & - & - & - & - & 1.47 & - & - & - & - & - \\
\hline $450-4-4$ & 32.29 & 1.580 & - & - & - & - & - & - & - & - & - \\
\hline $450-4-5$ & 33.25 & - & - & - & - & 1.56 & - & - & - & - & - \\
\hline $450-5-1$ & 36.75 & - & - & - & - & 1.50 & - & - & - & - & - \\
\hline $450-5-2$ & 38.25 & - & - & - & - & 1.56 & - & - & - & - & - \\
\hline $450-5-2$ & 38.62 & 1.560 & - & - & - & - & - & - & - & - & - \\
\hline $450-5-2$ & 38.97 & - & - & - & - & - & - & 46.84 & - & - & - \\
\hline $450-5-3$ & 39.75 & - & - & - & - & 1.49 & - & - & - & - & - \\
\hline $450-6-1$ & 46.25 & - & - & - & - & 1.41 & - & - & - & - & - \\
\hline $450-8-1$ & 65.25 & - & - & - & - & 1.51 & - & - & - & - & - \\
\hline $450-8-1$ & 65.57 & 1.571 & - & - & - & - & - & - & - & - & - \\
\hline $450-8-2$ & 66.75 & - & - & - & - & 1.34 & - & - & - & - & - \\
\hline $450-11-1$ & 93.12 & - & - & - & - & - & - & - & - & $\bar{n}$ & 2.93 \\
\hline $450-11-1$ & 93.13 & - & - & - & 1.541 & - & - & 44.61 & 68.74 & 2.730 & - \\
\hline $450-12-2$ & 104.54 & 1.798 & - & 1.754 & - & - & - & - & - & - & 2.80 \\
\hline $450-12-2$ & 104.55 & - & - & - & 1.596 & - & - & 40.42 & 64.52 & 2.680 & - \\
\hline $450-12-2$ & 104.75 & - & - & - & - & 1.54 & - & - & - & - & - \\
\hline $450-12-2$ & 105.45 & - & - & - & - & - & - & 37.24 & - & - & - \\
\hline $450-13-1$ & 112.12 & 1.701 & - & 1.680 & - & - & - & - & - & - & 2.69 \\
\hline $450-13-1$ & 112.13 & - & - & - & 1.599 & - & - & 39.64 & 63.39 & 2.637 & - \\
\hline $450-14-1$ & 122.25 & - & - & - & - & 1.58 & - & - & - & - & - \\
\hline $450-14-3$ & 125.25 & - & - & - & - & 1.58 & - & - & - & - & - \\
\hline $450-14-5$ & 128.25 & - & - & - & - & 1.65 & - & - & - & - & - \\
\hline $450-15-2$ & 133.25 & - & - & - & - & 1.53 & - & - & - & - & - \\
\hline $450-15-4$ & 136.25 & - & - & - & - & 1.56 & - & - & - & - & - \\
\hline 450-16-1 & 141.25 & - & - & - & - & 1.52 & - & - & - & - & - \\
\hline $450-16-3$ & 144.25 & - & - & - & - & 1.51 & - & - & - & - & - \\
\hline $450-16-3$ & 144.95 & - & - & - & - & - & - & 33.88 & - & - & - \\
\hline $450-16-5$ & 147.25 & - & - & - & - & 1.48 & - & - & - & - & - \\
\hline $450-16-6$ & 148.28 & 1.932 & - & 1.918 & - & - & - & - & - & $\overline{7}$ & 3.19 \\
\hline $450-16-6$ & 148.30 & - & - & - & 1.663 & - & - & 37.29 & 62.01 & 2.745 & - \\
\hline $450-17-1$ & 150.75 & - & - & - & - & 1.41 & - & - & - & - & - \\
\hline $450-17-3$ & 153.75 & - & - & - & - & 1.45 & - & - & - & - & - \\
\hline $450-17-5$ & 156.14 & 1.952 & - & 1.870 & - & - & - & - & - & - & - \\
\hline $450-17-5$ & 156.16 & - & - & - & 1.588 & - & - & 42.12 & 66.90 & 2.778 & - \\
\hline $450-17-5$ & 156.75 & - & - & - & - & 1.51 & - & - & - & - & - \\
\hline $450-18-2$ & 161.75 & - & - & - & - & 1.48 & - & - & - & - & $=$ \\
\hline $450-18-4$ & 164.27 & 1.822 & - & 1.787 & - & - & - & - & - & - & 2.69 \\
\hline $450-18-4$ & 164.28 & - & - & - & 1.506 & - & - & 47.67 & 71.78 & 2.792 & - \\
\hline $450-18-4$ & 164.75 & - & - & - & - & 1.48 & - & - & - & - & - \\
\hline $450-19-2$ & 171.25 & - & - & - & - & 1.54 & - & - & - & - & $\bar{x}$ \\
\hline $450-19-3$ & 172.69 & 1.962 & - & 1.876 & - & - & - & - & $=$ & $\overline{-1 \times}$ & 2.95 \\
\hline $450-19-3$ & 172.70 & - & - & - & 1.572 & - & - & 43.05 & 67.67 & 2.769 & - \\
\hline $450-19-4$ & 174.25 & - & - & - & - & 1.47 & - & - & - & - & - \\
\hline $450-20-1$ & 179.95 & - & - & - & - & - & - & 36.38 & - & - & - \\
\hline $450-20-2$ & 180.75 & - & - & - & - & 1.64 & - & - & - & - & - \\
\hline $450-21-1$ & 188.13 & 1.874 & - & 1.822 & - & - & - & - & - & - & 2.72 \\
\hline $450-21-1$ & 188.14 & - & - & - & 1.449 & - & - & 49.33 & 71.48 & 2.575 & - \\
\hline $450-21-2$ & 190.25 & - & - & - & - & 1.51 & - & - & - & - & - \\
\hline $450-21-4$ & 193.25 & - & - & - & - & 1.55 & - & - & - & - & - \\
\hline $450-22-1$ & 198.15 & 1.894 & - & 1.813 & - & - & - & - & - & - & 2.78 \\
\hline $450-22-1$ & 198.16 & - & - & - & 1.536 & - & - & 44.81 & 68.80 & 2.717 & - \\
\hline $450-24-1$ & 217.00 & 1.954 & - & 1.932 & - & - & - & - & - & - & 3.24 \\
\hline $450-24-1$ & 217.01 & - & - & - & 1.679 & - & - & 36.24 & 60.84 & 2.773 & - \\
\hline
\end{tabular}


Table 5. (Continued).

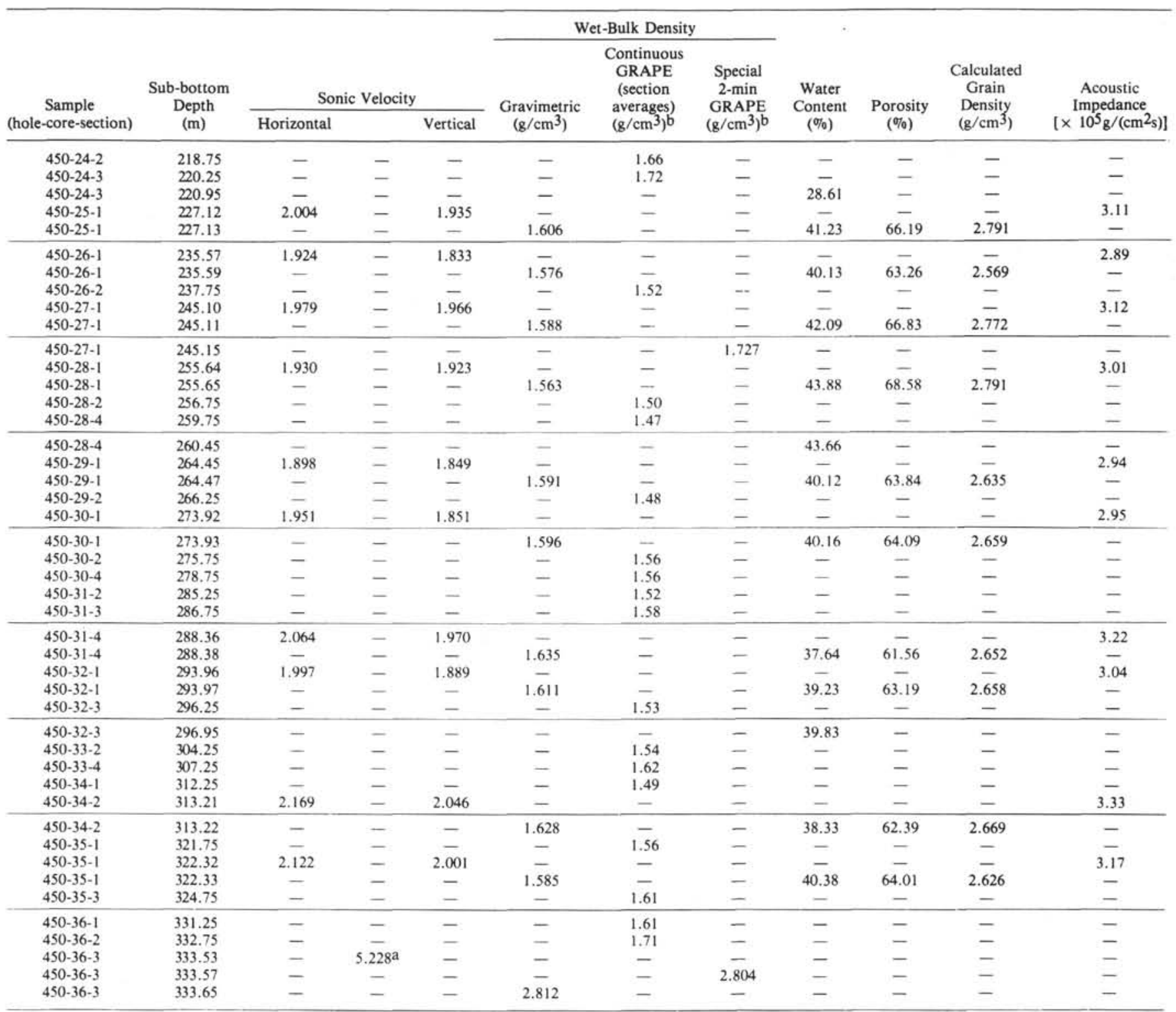

a Basalt average velocity.

b Based on an assumed grain density of $2.75 \mathrm{~g} / \mathrm{cm}^{3}$.

profile. The overlying reflectors simply appeared to be draped over the feature. On departure from Site 450, however, close inspection of the postsite survey profile revealed a suggestion of external centripetal dip in the deeper strata on either side of the feature, even though no structural deformation of the shallower reflectors over the feature was observed (such as reflector "white out" caused by ring fracturing). This could be taken to indicate that intrusion occurred almost penecontemporaneously with deposition of the intruded sediment.

Assuming an average sonic velocity of $1.83 \mathrm{~km} / \mathrm{s}$ for the sediment at the site, as determined by shipboard measurement on cored sediments from Hole 450 and a minimum of $0.33 \mathrm{~s}$ of reflection time (measured on the profile across the site at the time of the beacon drop), the shallowest depth at which the feature could have been expected to be encountered is 300 meters. Con- sidering the previously mentioned positioning problems, the narrow target pinnacle, and errors inherent in estimating depths from reflection profiles, the depth estimate is in good agreement with the actual depth of 333 meters at which the intrusive basalt was drilled at Hole 450.

\section{SUMMARY AND CONCLUSIONS}

Site 450 at $18^{\circ} 00.02^{\prime} \mathrm{N}$ and $140^{\circ} 47.34^{\prime} \mathrm{E}$ was drilled with the objective of determining the age and nature of the thick sedimentary apron west of the West Mariana Ridge and investigating the age and petrologic character of the apparent basement ridges within the sedimentary column. Continuous coring at Hole 450 resulted in a total recovery of 183 meters out of 340 meters drilled. Hole 450 was terminated at 340 meters because of failure of the main shaft bearing on the Bowen hydraulic 


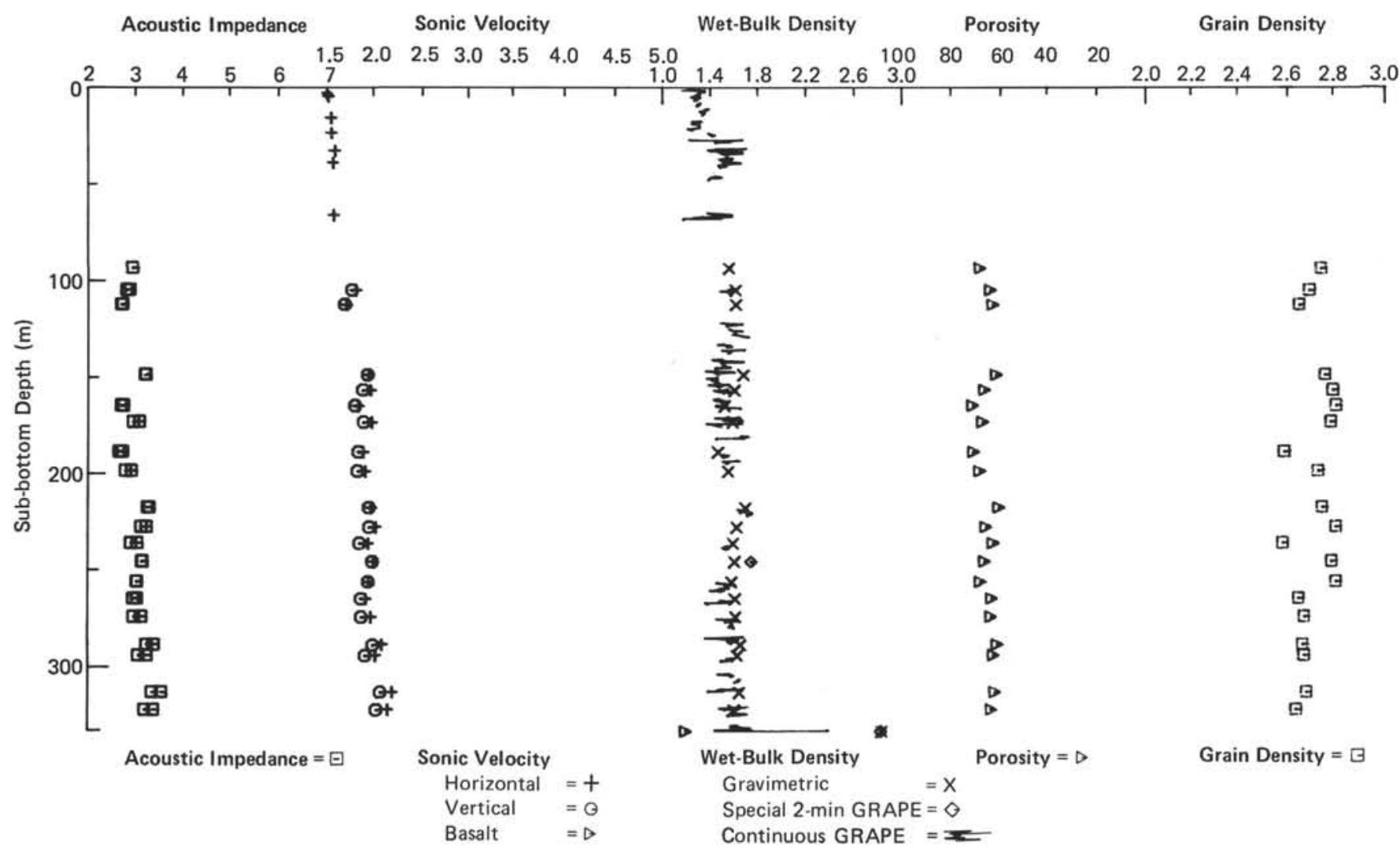

Figure 13. Physical properties of sedimentary and igneous rocks from Hole 450 plotted versus sub-bottom depth in meters. (Acoustic impedance is the product of velocity and bulk density. Sonic velocity measurements include horizontal and vertical velocity of sediments and average velocity of basalts. Gravimetric determinations of wet-bulk density are shown. Special 2-minute and continuous GRAPE determinations of wet-bulk density are also shown, based on an assumed grain density of $2.75 \mathrm{~g} / \mathrm{cm}^{3}$. Porosity was determined gravimetrically, and grain density was calculated from porosity and bulk density.)

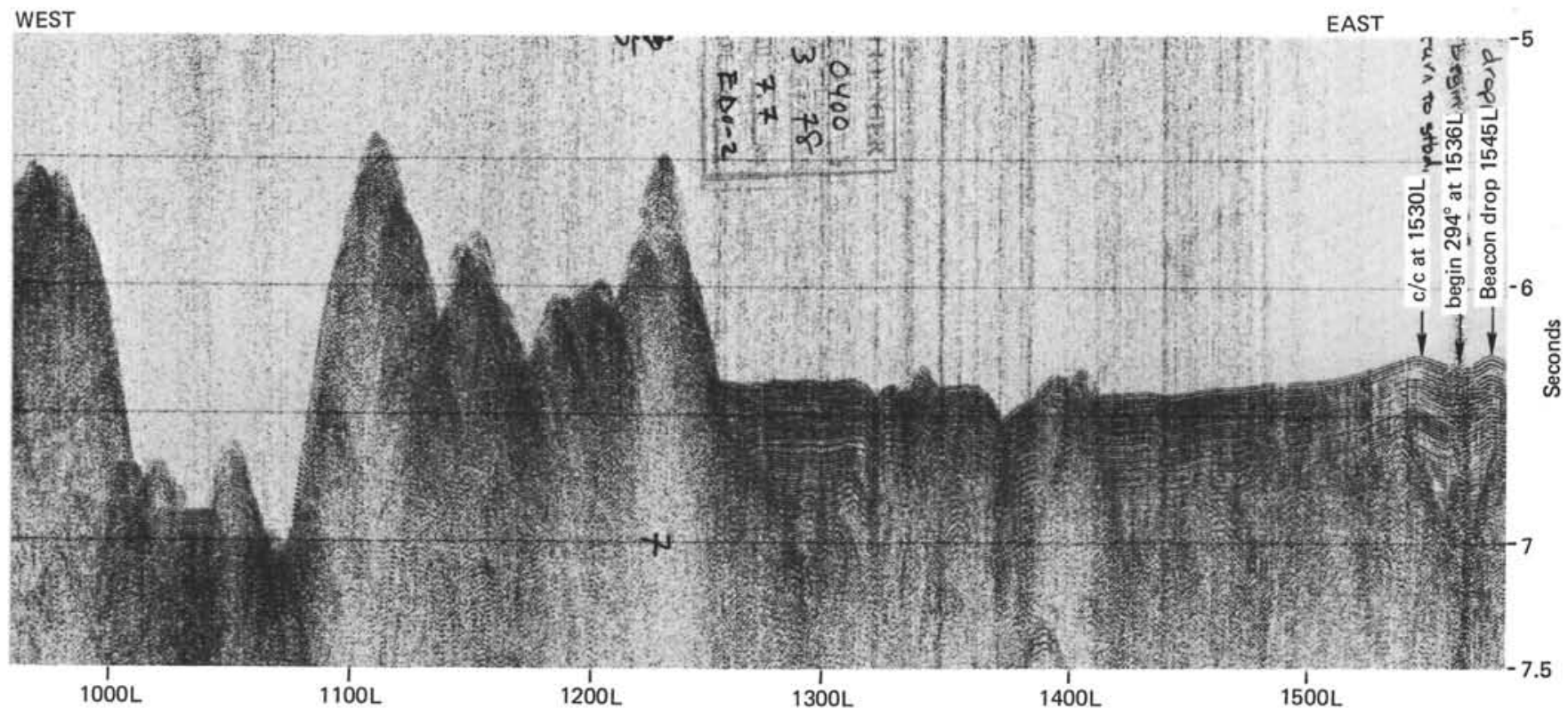

Figure 14. Reflection profile across Site 450 recorded during the approach to the site on board the Glomar Challenger. 
unit motor. Sediments were cored to a depth of 333.0 meters; below that level 1.7 meters of intrusive basaltic pillow lavas were recovered in the last 7 meters of drilling. Thus basement age and character remain undetermined.

A total of three major lithologic units were identified. The sedimentary section is divided into two lithologic units containing five sub-units that range between the middle Miocene and Pleistocene. The intrusive igneous sequence is probably nearly contemporaneous with sedimentation and contains only one phenocryst mineralogy.

The sedimentary section consists of:

Unit $1(0.0-83.5 \mathrm{~m})$, middle Miocene to Pleistocene pelagic clays, divided into two sub-units:

Sub-unit 1a (0.0-26.5 m), upper Miocene(?) to Pleistocene dark brown pelagic clay, devoid of ash; and

Sub-unit 1b (26.5-83.5 m), middle to upper Miocene dark brown to gray-brown pelagic clay with ash.

Unit 2 (83.5-333.0 m), middle Miocene monotonous, dark gray vitric tuffs, divided into three sub-units:

Sub-unit 2a (83.5-324.5 m), middle Miocene dark gray vitric tuffs with little pelagic clay;

Sub-unit $2 \mathrm{~b}(324.5-333.0 \mathrm{~m})$, barren, pale reddish brown hydrothermally altered tuffs, containing abundant zeolites; and

Sub-unit 2c (about $1 \mathrm{~cm}$ thick, base is $333.0 \mathrm{~m}$ ), barren, pale yellowish white, baked and leached tuff at the contact with pillow basalt.

Unit 3 (333.0-340.0 m), plagioclase-clinopyroxeneolivine-phyric intrusive pillow basalt.

Based upon data on radiolarians, the top of Core 1 can be assigned to the lower Pleistocene. Both nannoplankton and radiolarians indicate the upper Miocene for Cores 4 and 5 ; nannoplankton zone boundaries between Cores 6 and 7 (NN 9/NN 8), in Core 8 (NN 8/NN 7), between Cores 12 and 13 (NN 7/NN 6), and in Core 18 (NN 6/NN 5 and NN 5 down to $324.6 \mathrm{~m}$ ) all indicate progressively older zones of the middle Miocene.

Etching of calcareous nannofossils below 311.5 meters and absence of them below 324.5 meters is attributed to leaching by acidic hydrothermal waters associated with the intrusion of the underlying basalt encountered at 330.0 meters sub-bottom.

Sediments below 46.5 meters contain nannofossils and therefore were deposited above the CCD; but above 36.0 meters, the sediments lack calcareous fossils and were probably deposited below the CCD. Too few benthic foraminifers are present, however, to make a precise environmental interpretation.

Rates of accumulation vary as a function of ash content. From the latest middle Miocene to early Pleistocene, the rate was somewhat greater than $2 \mathrm{~m} / \mathrm{m}$.y.; principally only pelagic clay accumulated in this part of the Parece Vela Basin. From the top of Sub-unit 1b to the lowest fossil boundary (NN 6/NN 5) in Unit 2, an accumulation rate of ash is estimated to be slightly greater than $50 \mathrm{~m} / \mathrm{m} . \mathrm{y}$.; this rate is extrapolated to the base of the unit because of the uniform lithology. Extrapolation of this sedimentation rate to the bottom of the hole gives a sediment age of about 17 m.y. and an apparent basement age of 23 to $24 \mathrm{~m} . \mathrm{y}$. at the predicted basement depth of 700 meters sub-bottom (off the flanks of the piercement, nearby the site). Using logical reconstruction, this age seems considerably too old, assuming that the age of the eastern boundary of the Parece Vela Basin is between 30 and $32 \mathrm{~m}$.y. old and the central spreading center ceased activity about $18 \mathrm{~m} . \mathrm{y}$. ago (Langseth and Mrozowski, this volume). Thus it is probable that rates of sedimentation are not linear below the NN 6/NN 5 Zone boundary but increase with depth.

Although petrographic studies cannot distinguish between the plagioclase-clinopyroxene-olivine-phyric basalts at Site 450 and those found at normal oceanic basements, these basalts are intrusive pillow lavas within sediments and as such cannot be considered basement. The hydrothermally altered zone above the basalt, an obvious baked tuffaceous contact, several metamorphosed tuffaceous inclusions between and within pillows, and tiny jetlike vents of lava that intruded the baked contact all require an intrusive origin. The pillowlike forms suggest that the intrusion occurred in unconsolidated tuffs by a process of soft-sediment deformation close to the sea-water/sediment interface. The most plausible interpretation of these intrusive relationships is that off-axis diapirlike intrusions penetrated the basin behind the West Mariana arc in the middle Miocene.

Because the age of the basement at Sites 450,53, and 54 is not well known and because the magnetic-anomaly pattern has not yet been identified on the eastern side of the Parece Vela Basin, the mode of formation of the basin is still somewhat questionable. Geologic and magnetic-anomaly evidence from the western half of the Parece Vela Basin strongly support the hypothesis that the basin was formed by symmetrical spreading about the Parece Vela Rift (at a half rate of between 2.7 and $3.2 \mathrm{~cm} / \mathrm{yr}$, with cessation between 18 and $13 \mathrm{~m} . \mathrm{y}$. ago, Scott et al., this volume). However, it yet is to be proven that the eastern half formed in such a fashion. Perhaps the portion of a back-arc basin closest to the active arc may be affected by both tectonic and magmatic modes of formation that differ from those affecting the more distal portion. Such seems to be the case in both the Shikoku and eastern Parece Vela basins, where abundant intrusions into the sedimentary sequence are preserved. At Hole 447 in the eastern part of the West Philippine Basin, the sedimentologic evidence of tectonic activity near the Palau-Kyushu active arc as well as the extremely rough basement in the eastern Parece Vela Basin may also be evidence of such effects. In addition, deep grabenlike structures, postdating deposition of the volcaniclastic sediment (post middle Miocene), are present in the eastern Parece Vela Basin (Langseth and Mrozowski, this volume). Thus, although the basic framework of basin formation may be approximately symmetrical, the arc side of back-arc basins seems to be different in some aspects; unfortunately the extent and nature of these differences are obscured by the thick wedges of volcaniclastic sediments that have also accumulated on the arc side of back-arc basins. 
The sequence of probable events at Site 450 from oldest to youngest can be summarized as follows:

1) Basaltic basement formed beneath the eastern side of the Parece Vela Basin at some undetermined time prior to deposition of middle Miocene tuffs, probably during the early Miocene.

2) A thick wedge of volcaniclastic sediments derived from the active West Mariana arc accumulated at rates in excess of $50 \mathrm{~m} / \mathrm{m} . \mathrm{y}$. (perhaps as great as $100 \mathrm{~m} / \mathrm{m} . \mathrm{y}$.) in the vicinity of Site 450 for about 2 or $3 \mathrm{~m} . \mathrm{y}$.

3) Basaltic intrusions rose through the poorly consolidated tuffs during off-axis type of magmatic activity, creating piercement structures and subsediment pillow basalt injections in low-density sediment-sea water slurries. Both intrusive and "extrusive" features were formed.

4) Tuffs continued to accumulate at rates slightly greater than $50 \mathrm{~m} / \mathrm{m}$.y. throughout the middle Miocene, that is, for about another 5 m.y. After this period, the supply of volcanic debris on the back-arc side of the West Mariana arc was apparently shut off by cessation of the volcanic activity along the West Mariana arc.

5) Since the middle Miocene, the region migrated about $8^{\circ}$ north.

6) After the middle Miocene, the basin subsided below the CCD and only pelagic clay accumulated at a rate slightly greater than $2 \mathrm{~m} / \mathrm{m}$.y. until the early Pleistocene. Circumstantial evidence thus links cessation of arc volcanism with subsidence of back-arc basins and with formation of deep grabenlike structures on the eastern side of the basin during subsidence.

\section{REFERENCES}

Bonatti, E., Kolla, V., Moore, D. S., et al., 1979. Metallogenesis in marginal basins: Fe-rich basal deposits from the Philippine Sea. Mar. Geol., 32:21-37.
Dietrich, V., Emmermann, R., Oberhansli, R., et al., 1978. Geochemistry of the basaltic and gabbroic rocks from the West Mariana Basin and the Mariana Basin and the Mariana Trench. Earth Planet. Sci. Lett., 39:127-144.

Fischer, A. G., Heezen, B.C., et al., 1971. Init. Repts. DSDP, 6: Washington (U.S. Govt. Printing Office).

Hart, S. R., Glassley, W. E., and Karig, D. E., 1972. Basalts and seafloor spreading behind the Mariana Island arc. Earth Planet. Sci. Lett., 15:12-18.

International Working Group on the IGCP Project "Ophiolites," 1977. Initial report of the geological study of oceanic crust of the Philippine Sea floor. In Bogdanov, N. (Ed.), Bolletino del Grupo di Lavoro aulle Ofioliti Mediterranee, (Vol. 2): Bologna (Estratto da Ofioliti), 137-168.

Karig, D. E., 1975. Basin genesis in the Philippine Sea. In Karig, D. E., Ingle, J. C., Jr., et al., Init. Repts. DSDP, 31:Washington (U.S. Govt. Printing Office), 857-879.

Klein, G. deV., Kobayashi, K., et al., in press. Init. Repts. DSDP, 58 : Washington (U.S. Govt. Printing Office).

Martini, E., 1971. Standard Tertiary and Quaternary calcareous nannoplankton zonation. Proc. Second Planktonic Conference, Rome, 1970, 2:739-785.

1976. Cretaceous to Recent calcareous nannoplankton from the Central Pacific Ocean (DSDP Leg 33). In Schlanger, S. O., Jackson, E. D., et al., Init. Repts. DSDP, 33: Washington (U.S. Govt. Printing Office), 383-423.

Mrozowski, D. L., and Hayes, D. E., 1979. The evolution of the Parece Vela Basin, Eastern Philippine Sea. Earth Planet. Sci. Lett., 46:49-67.

Murauchi, S., Den, N., Asano, S., et al., 1968. Crustal structure of the Philippine Sea. J. Geophys. Res., 73:3143-3171.

Schlanger, S. O., Jackson, E. D., et al., 1976. Init. Repts. DSDP, 33: Washington (U.S. Govt. Printing Office).

Thompson, G., 1973. A geochemical study of the low-temperature interaction of sea water and oceanic igneous rocks. Trans. Am. Geophys. Union, 54:1015-1019. 


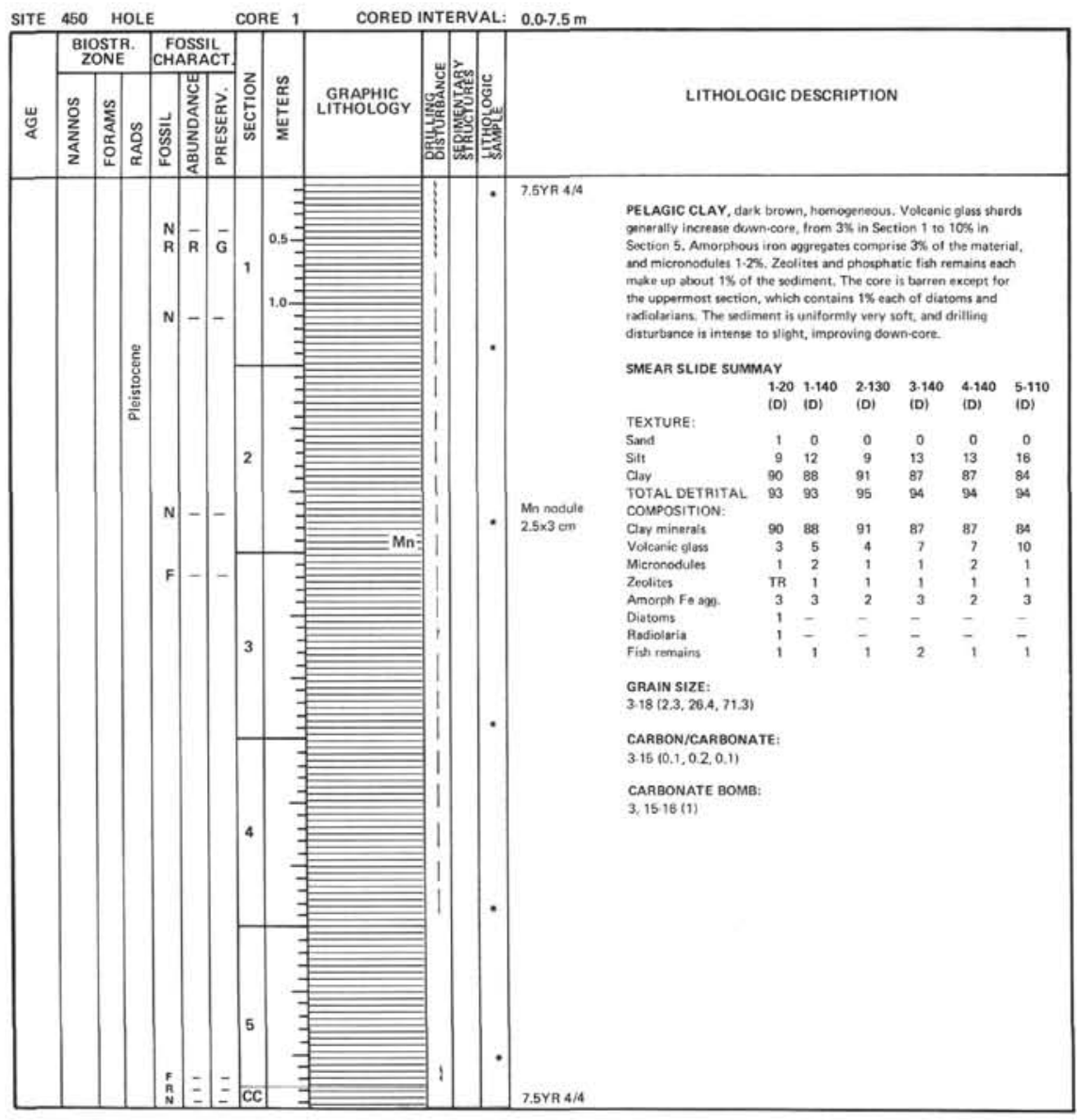

SITE 450 HOLE CORE 2 CORED INTERVAL: $7.5-17.0 \mathrm{~m}$

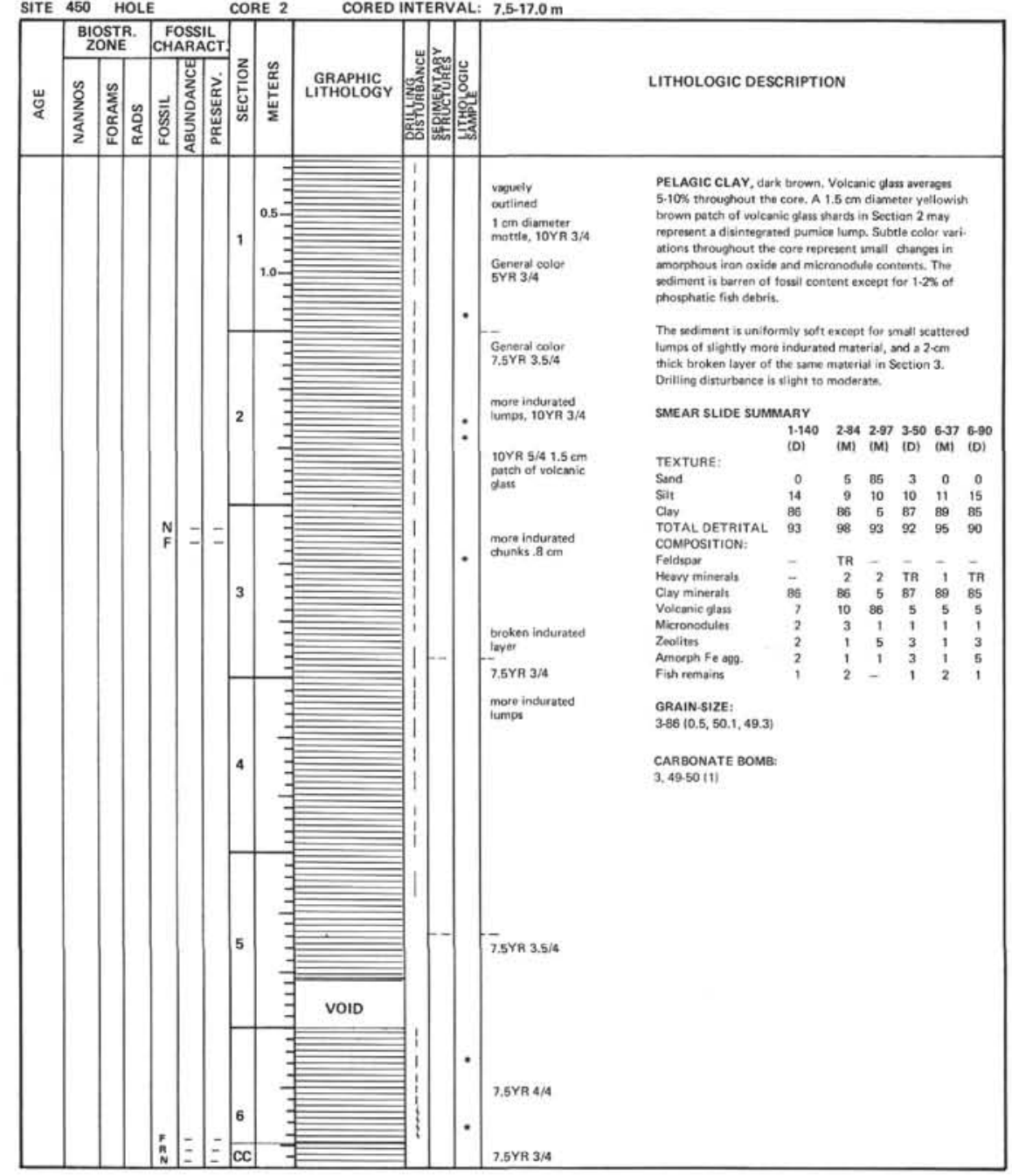




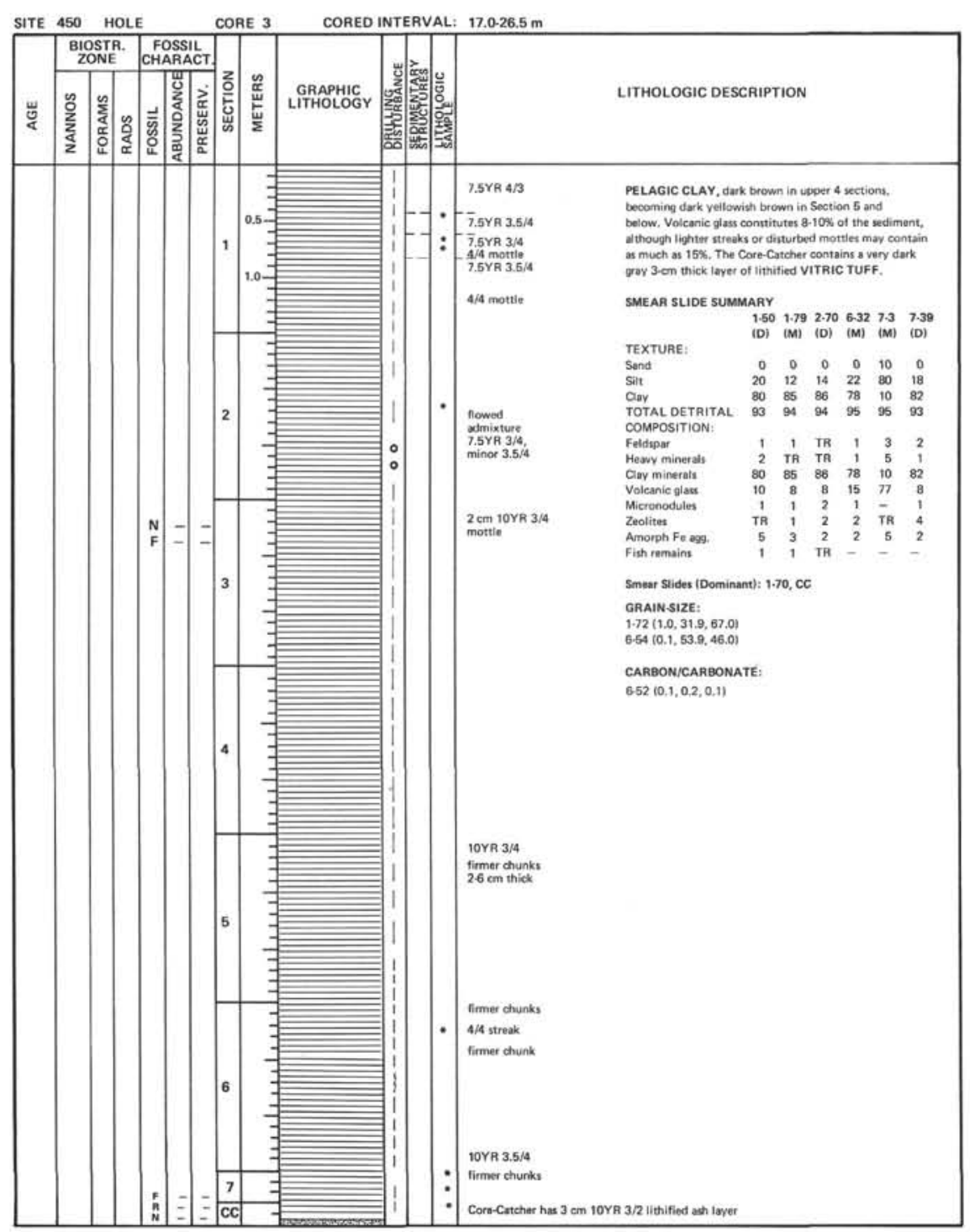

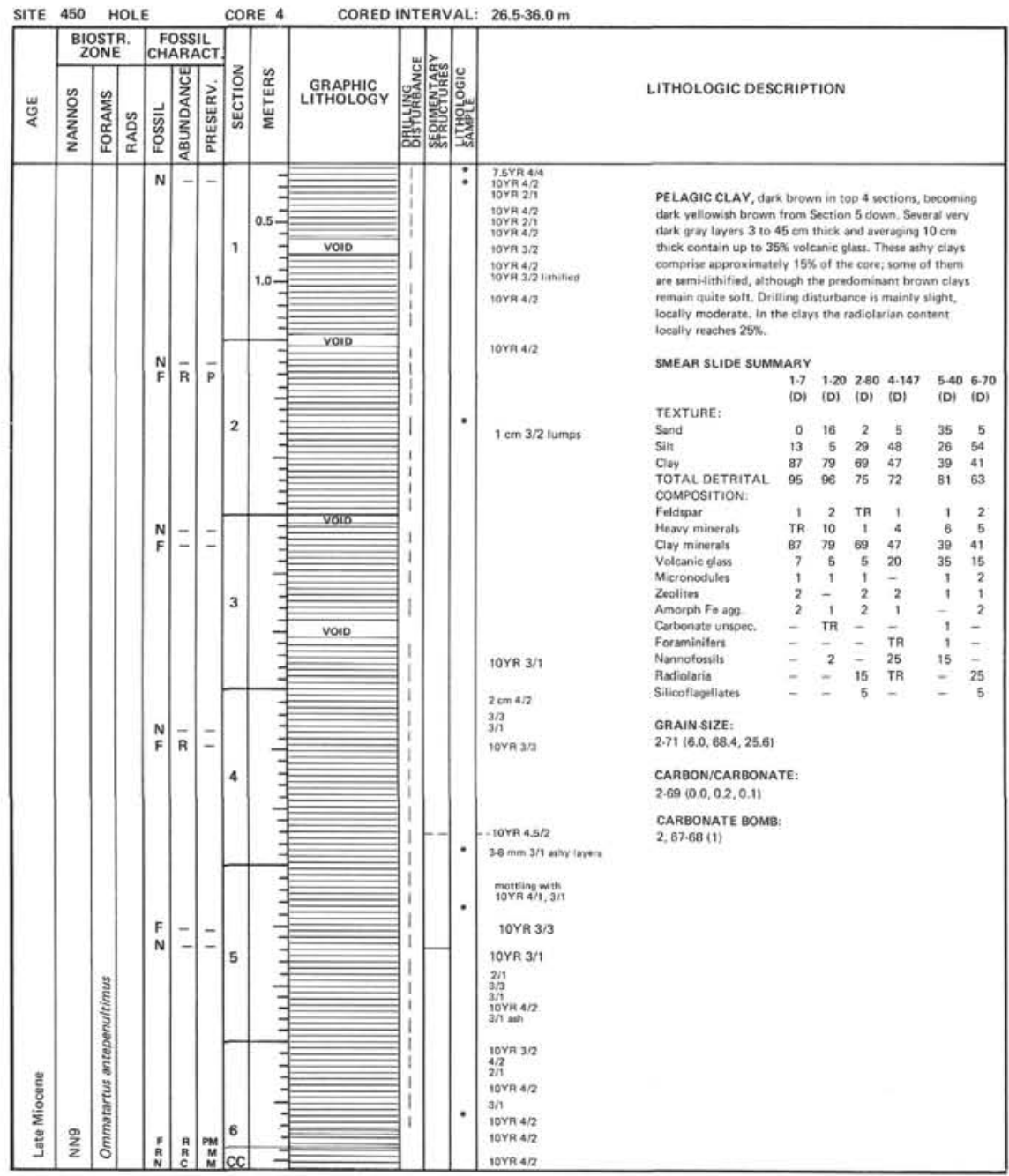




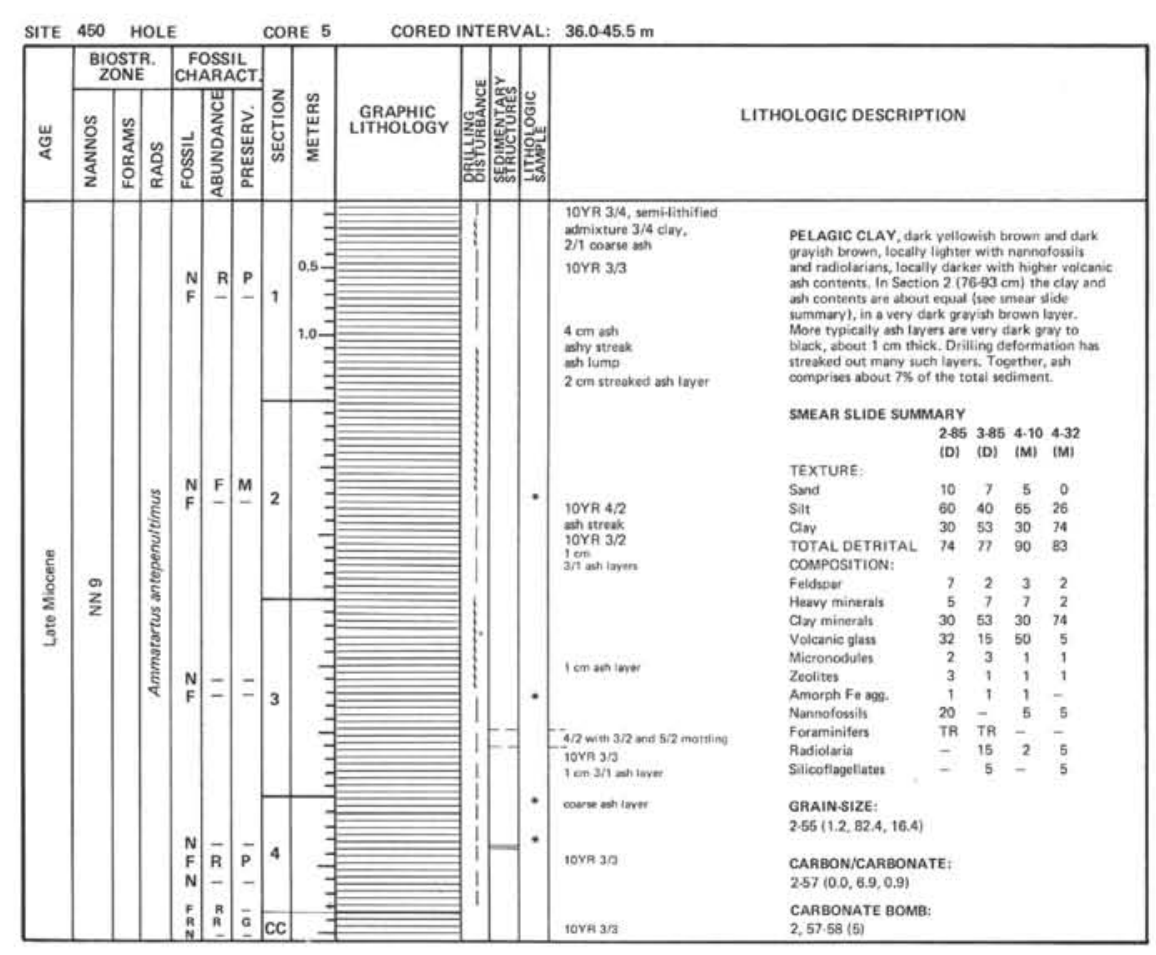

SITE 450 HOL CORE 6 CORED INTERVAL: 45.555 .0

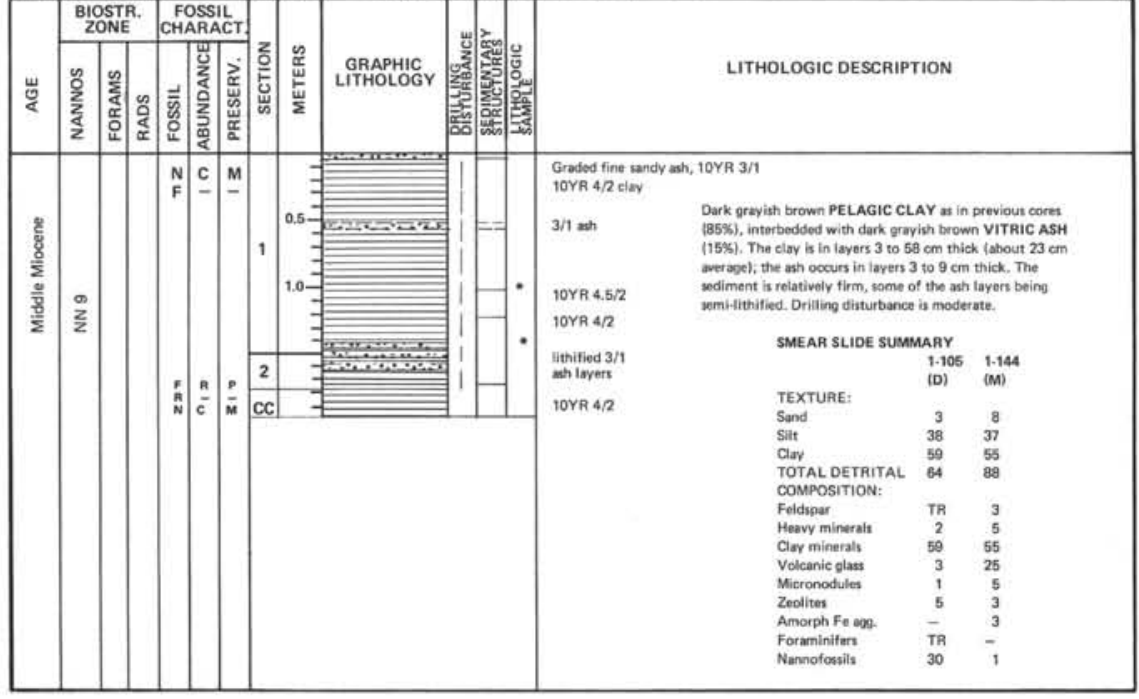

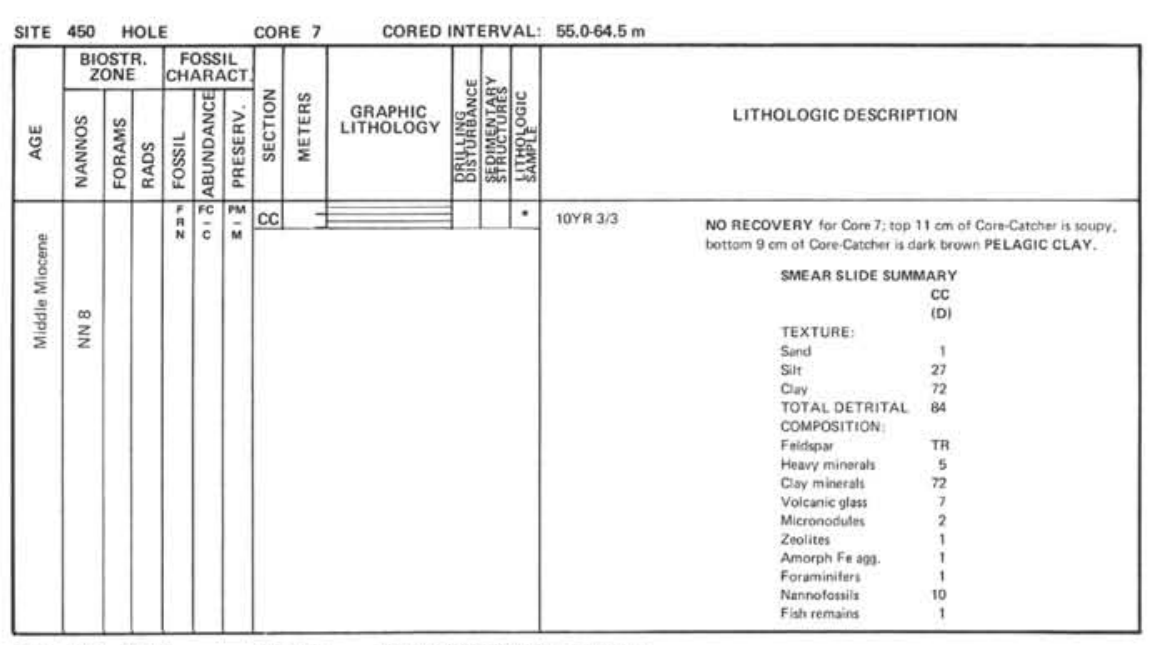

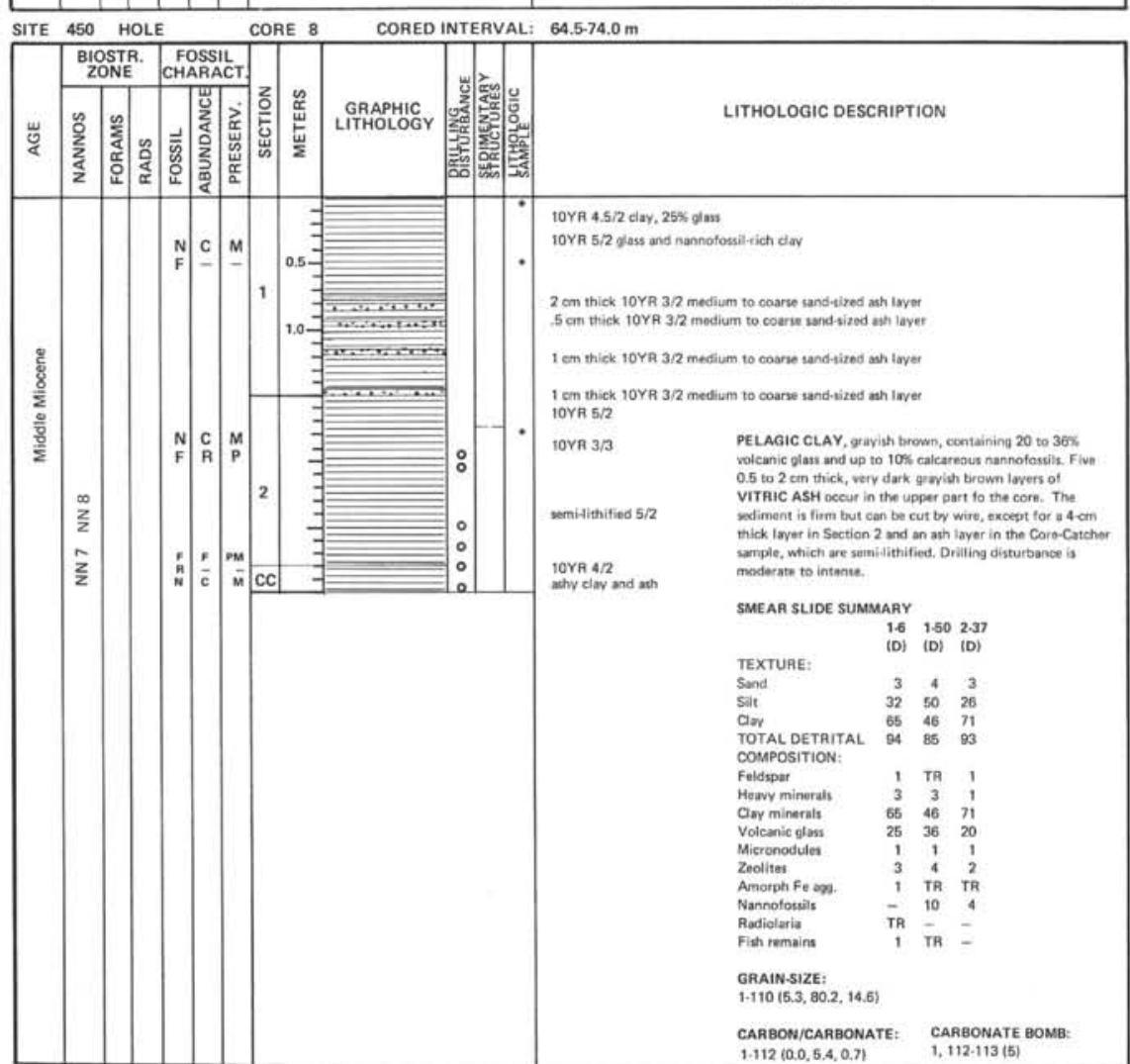


SITE 450 HOLE CORE 9 CORED INTERVAL: $74.0 .83 .5 \mathrm{~m}$

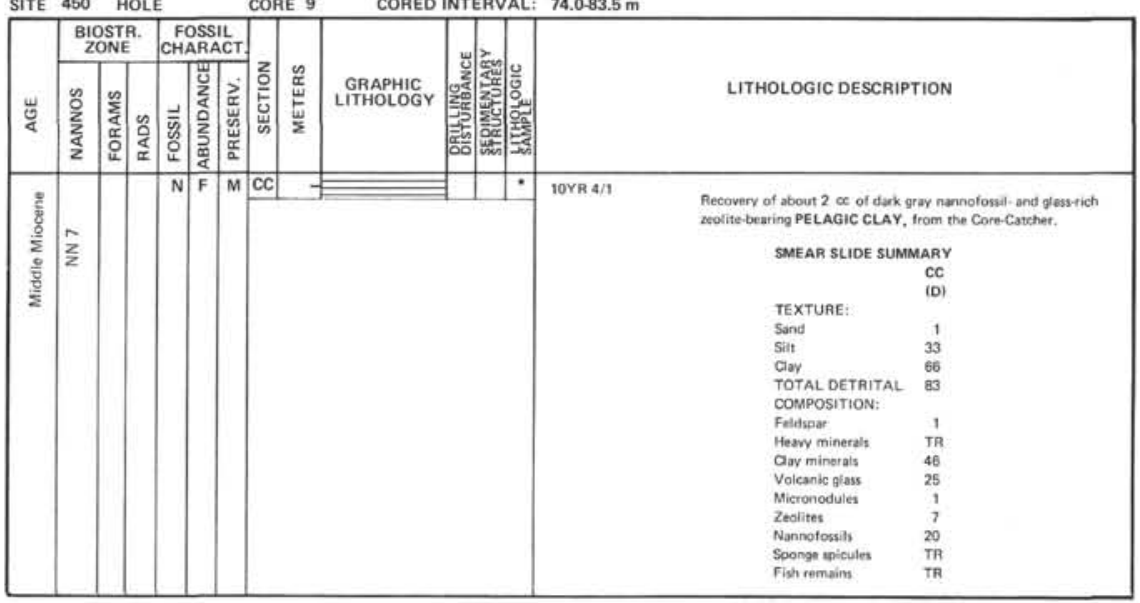

SITE 450 HOLE
\begin{tabular}{|l|l|l|l|l}
\hline & CORE 10 & CORED INTERVAL: $83.5 .93 .0 \mathrm{~m}$
\end{tabular}

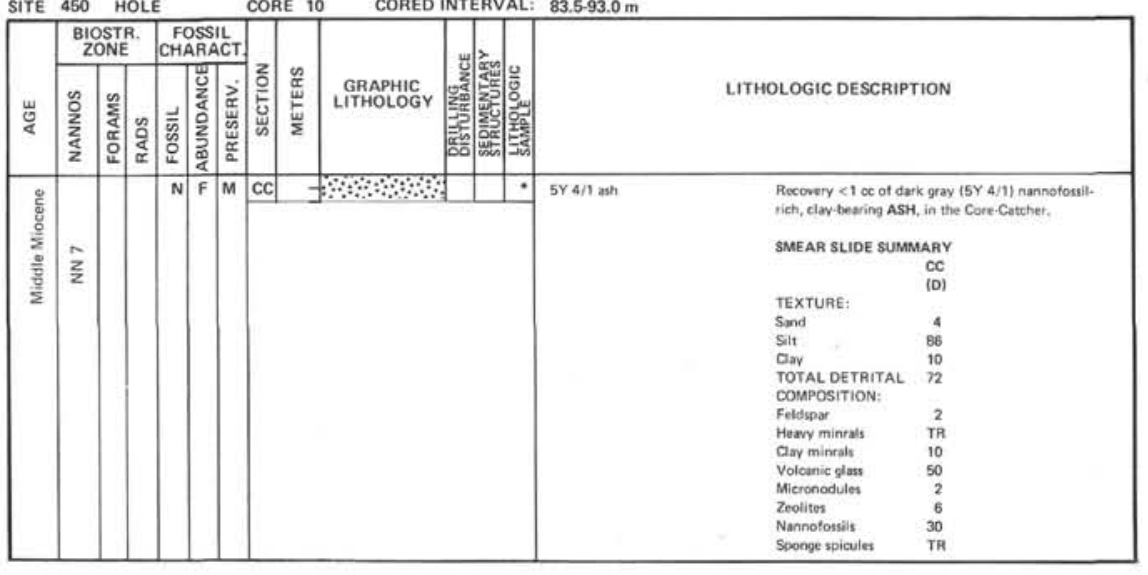

SITE 450 HOLE CORE 11 CORED INTERVAL: $93.0-102.5 \mathrm{~m}$

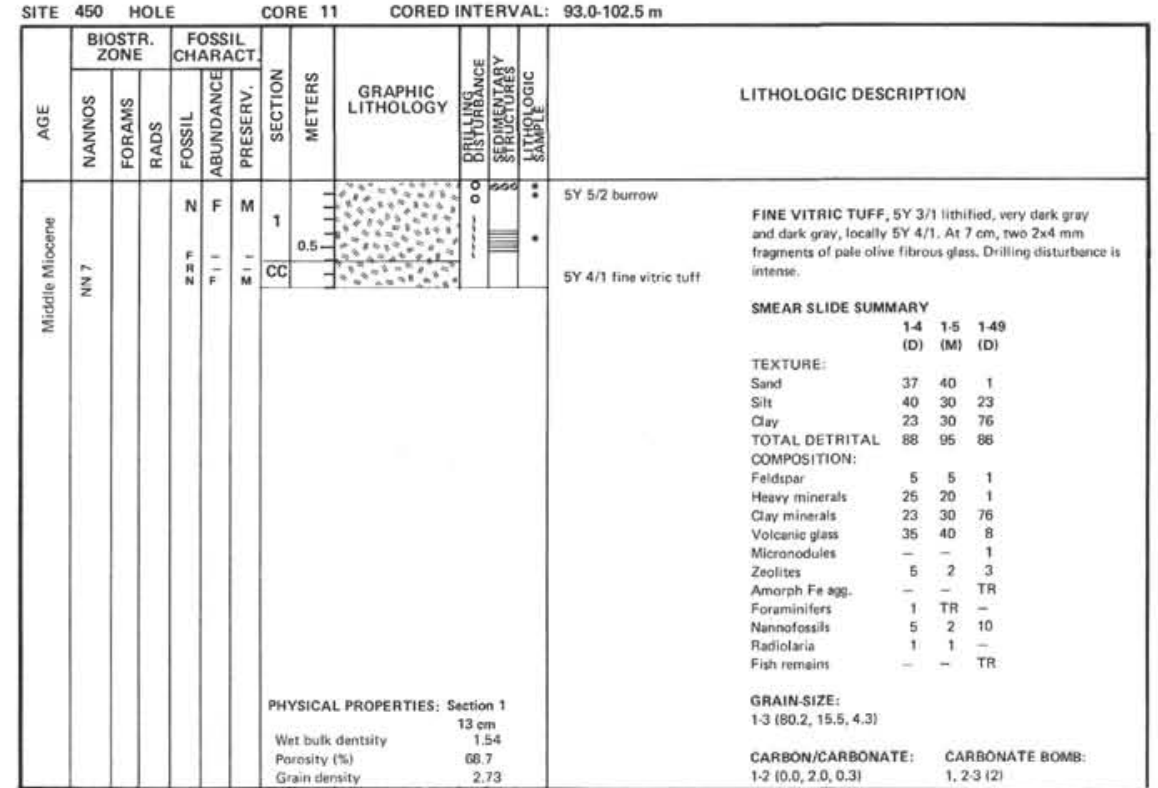

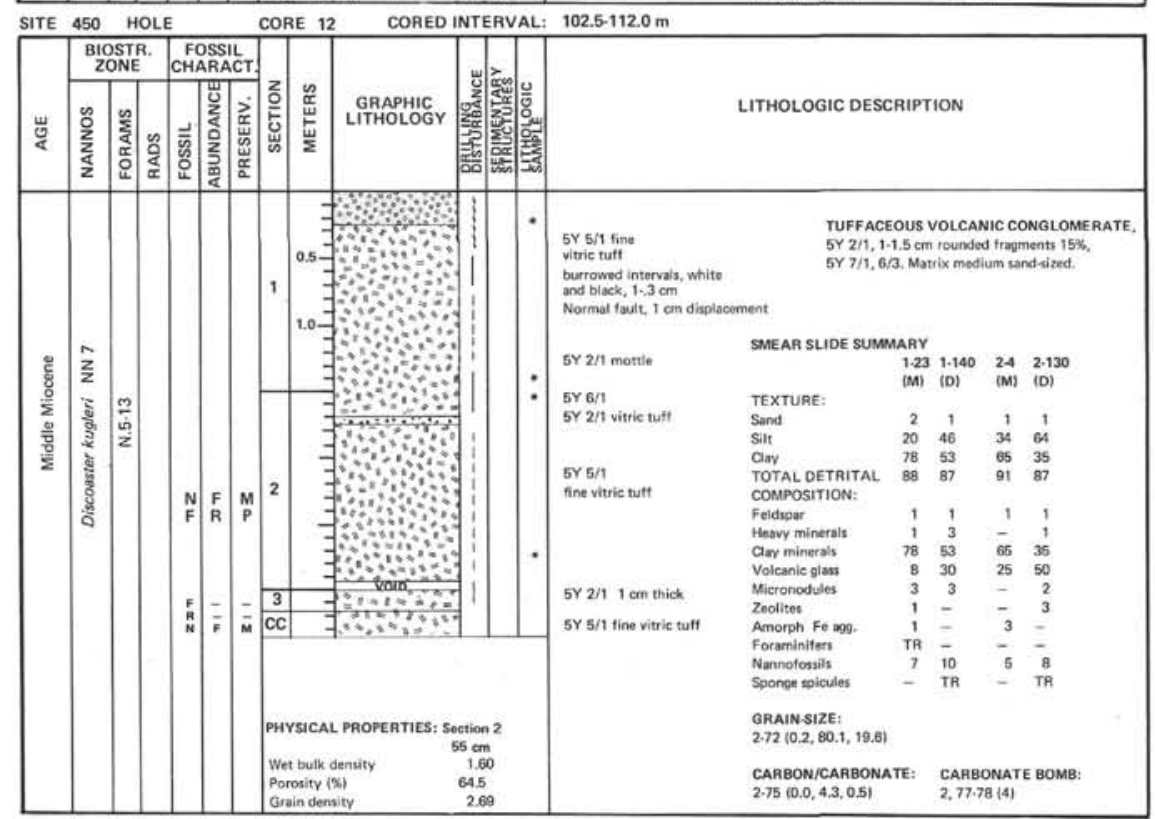



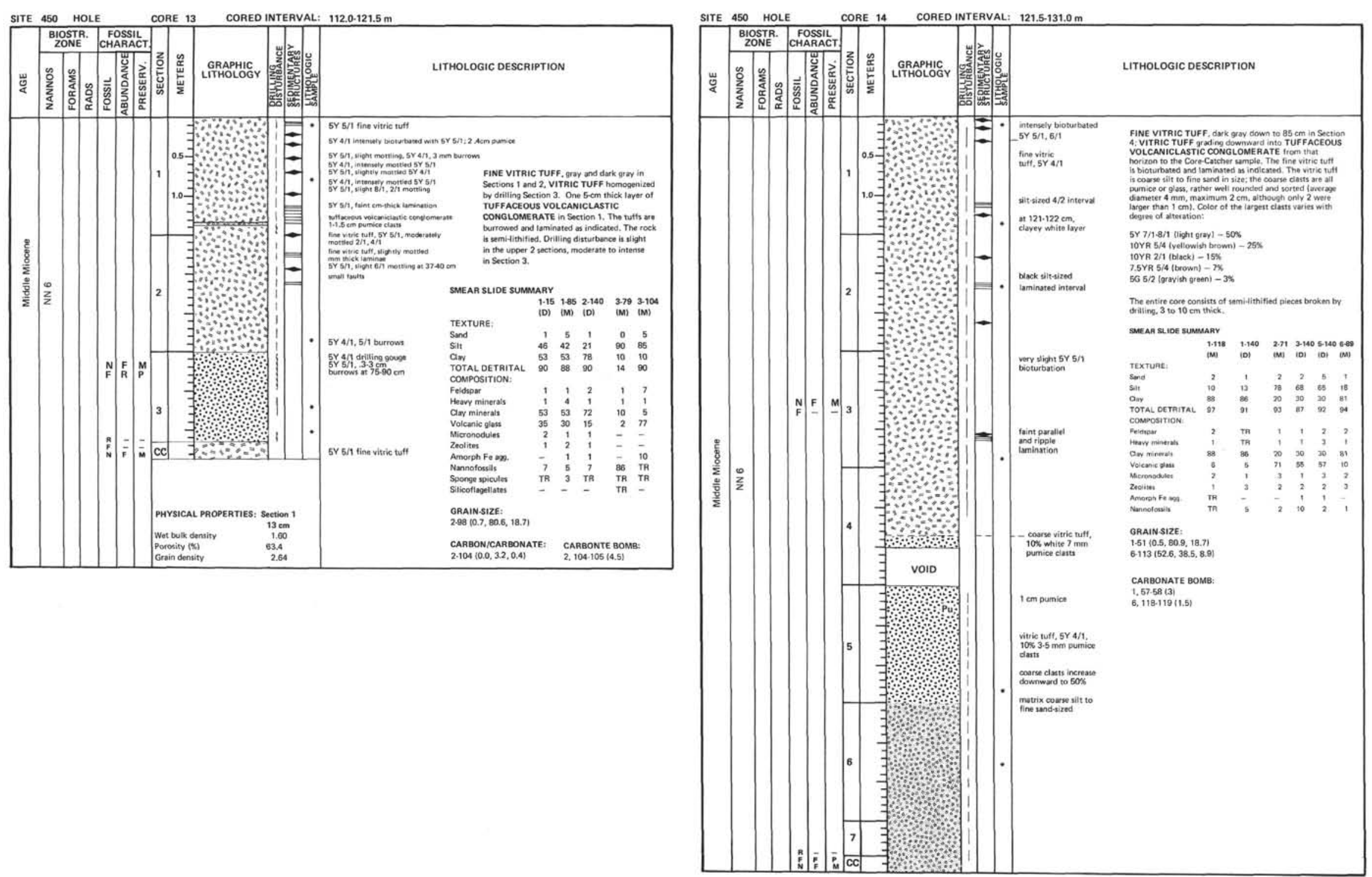

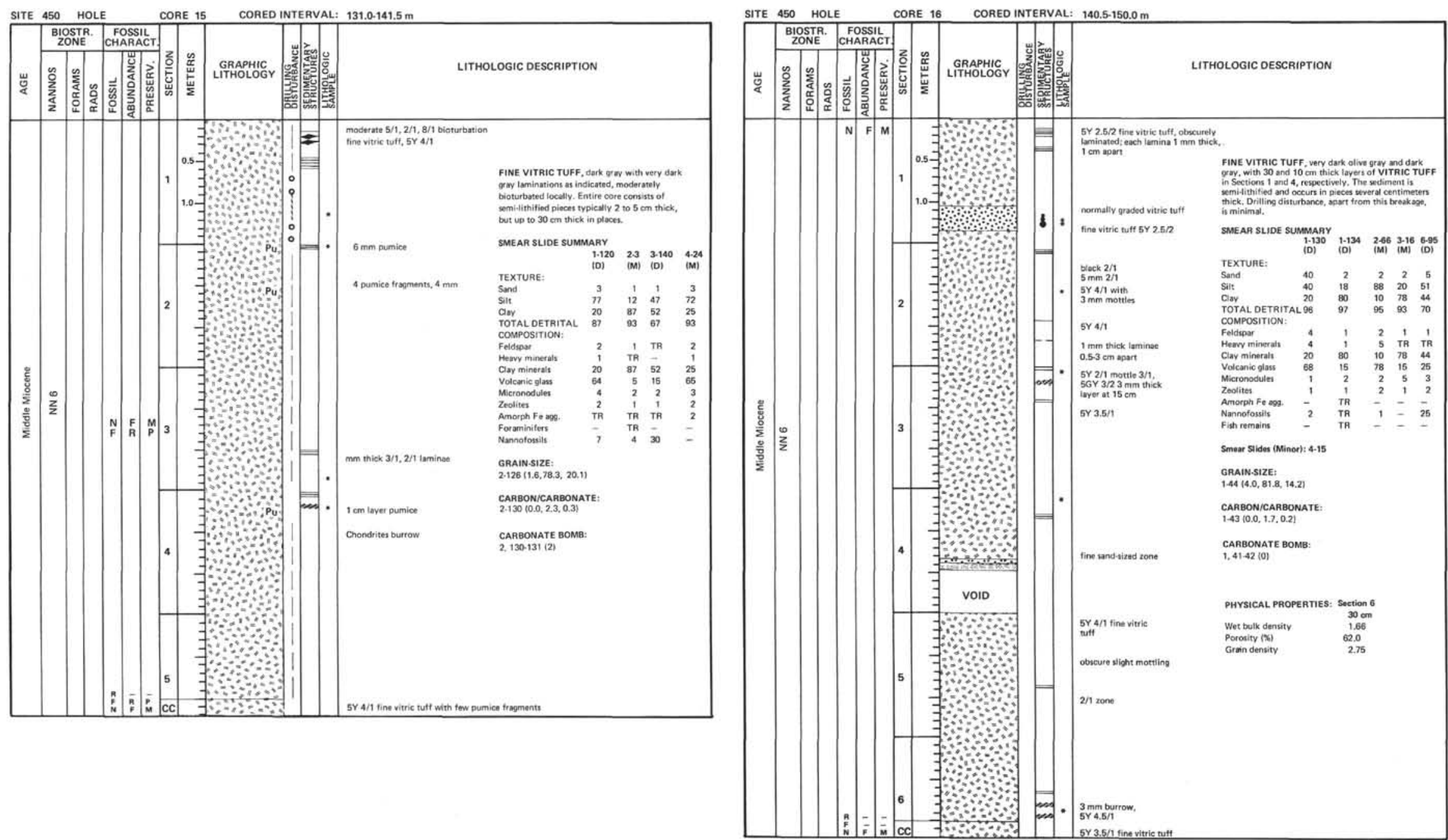


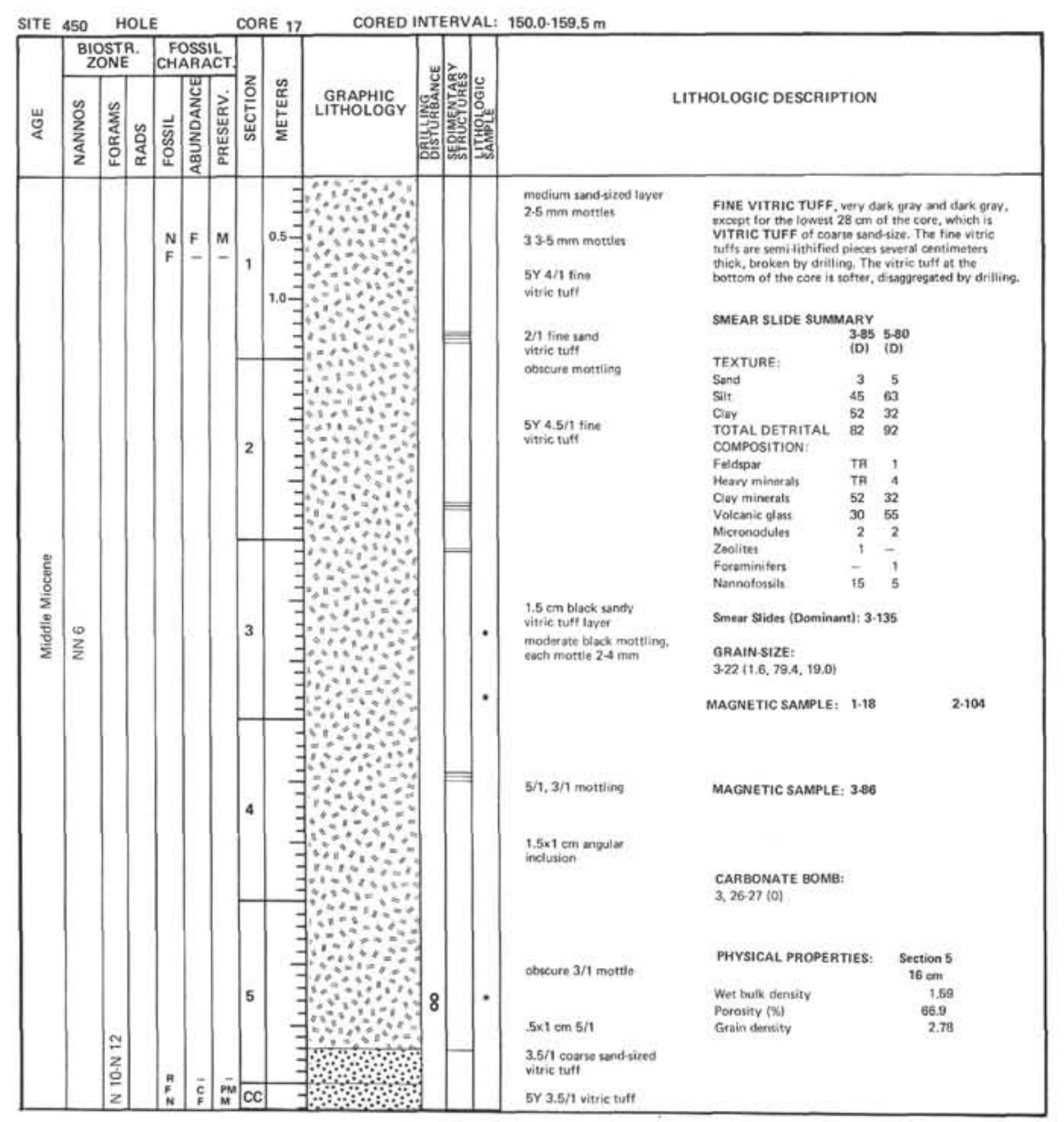

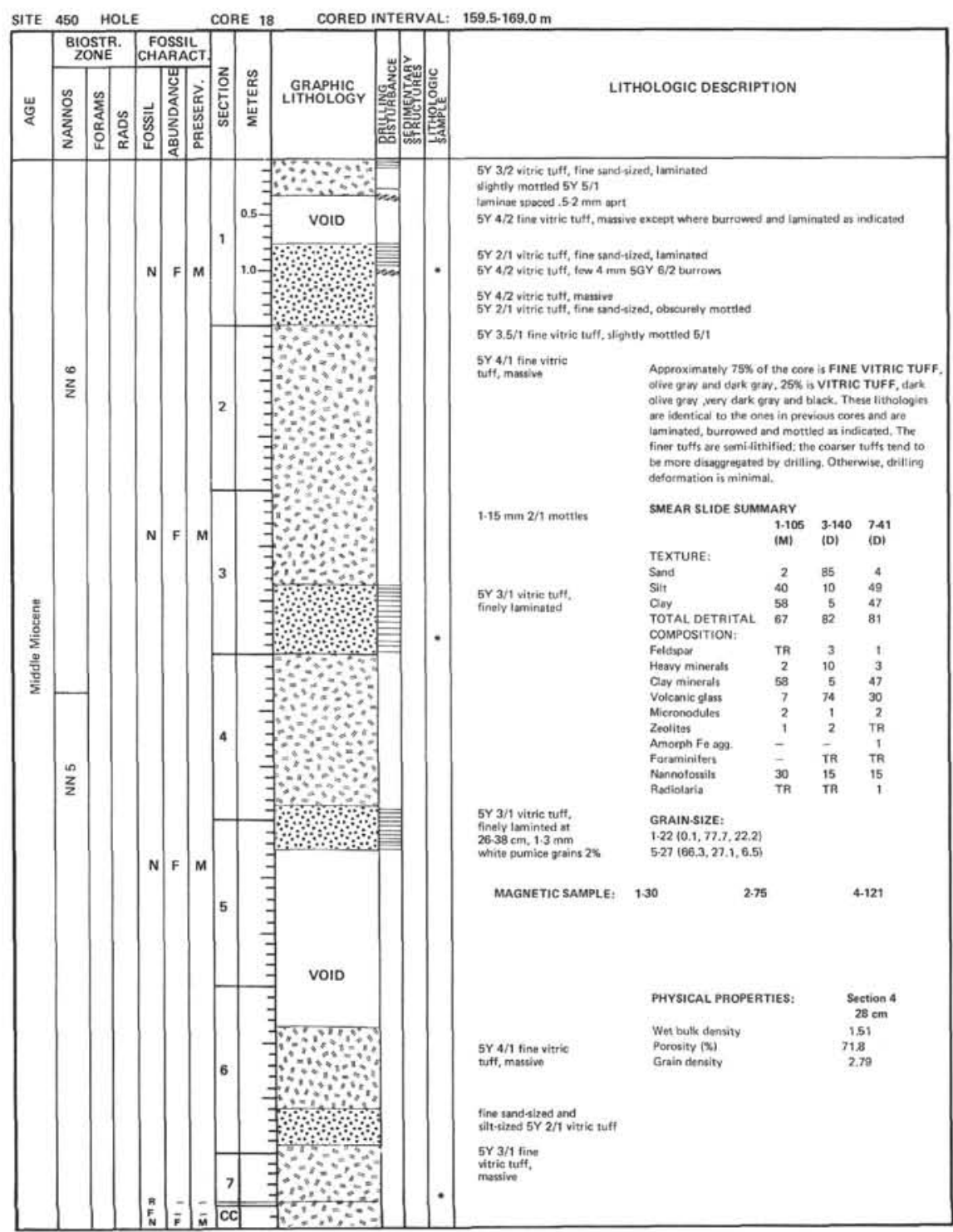




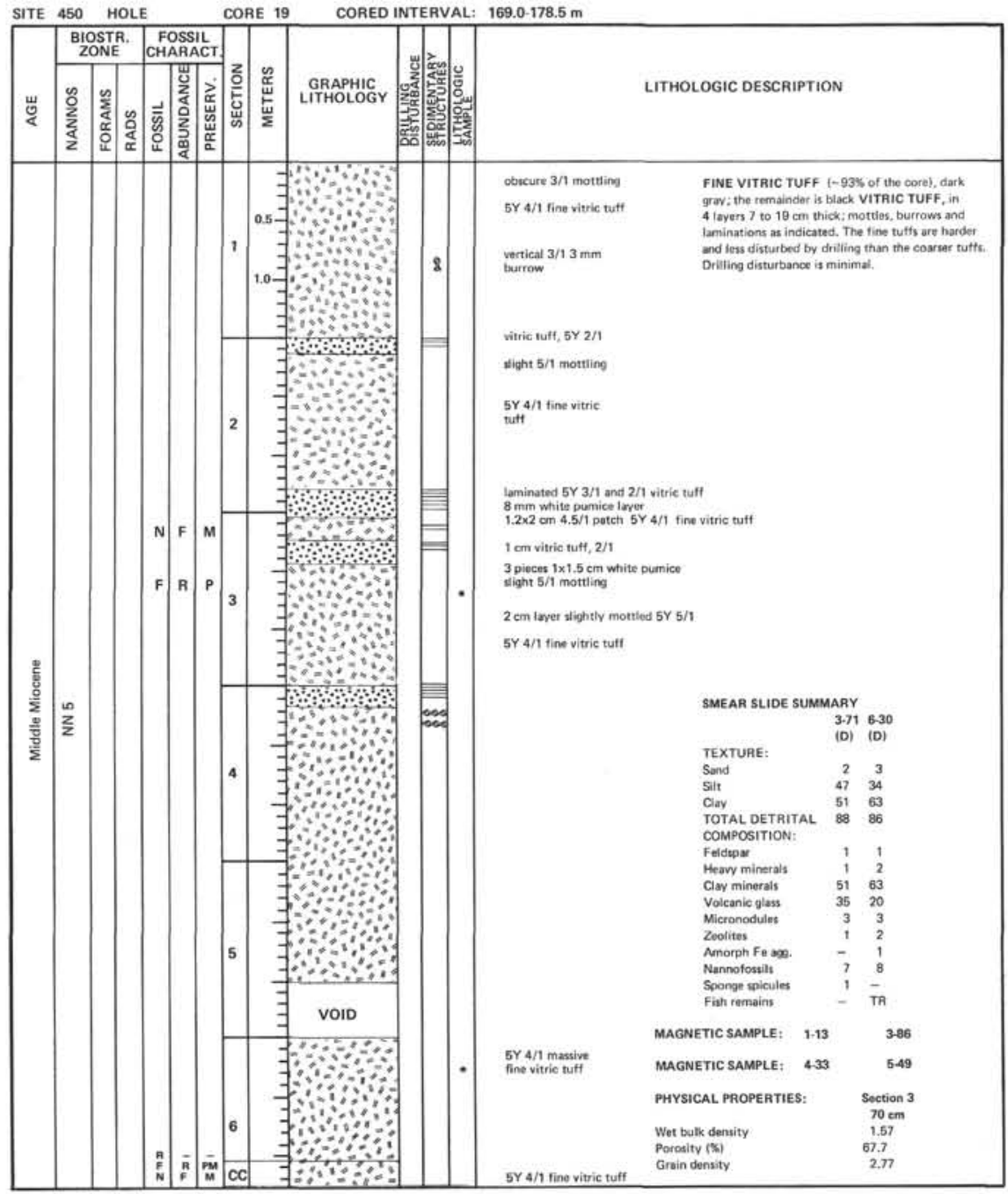

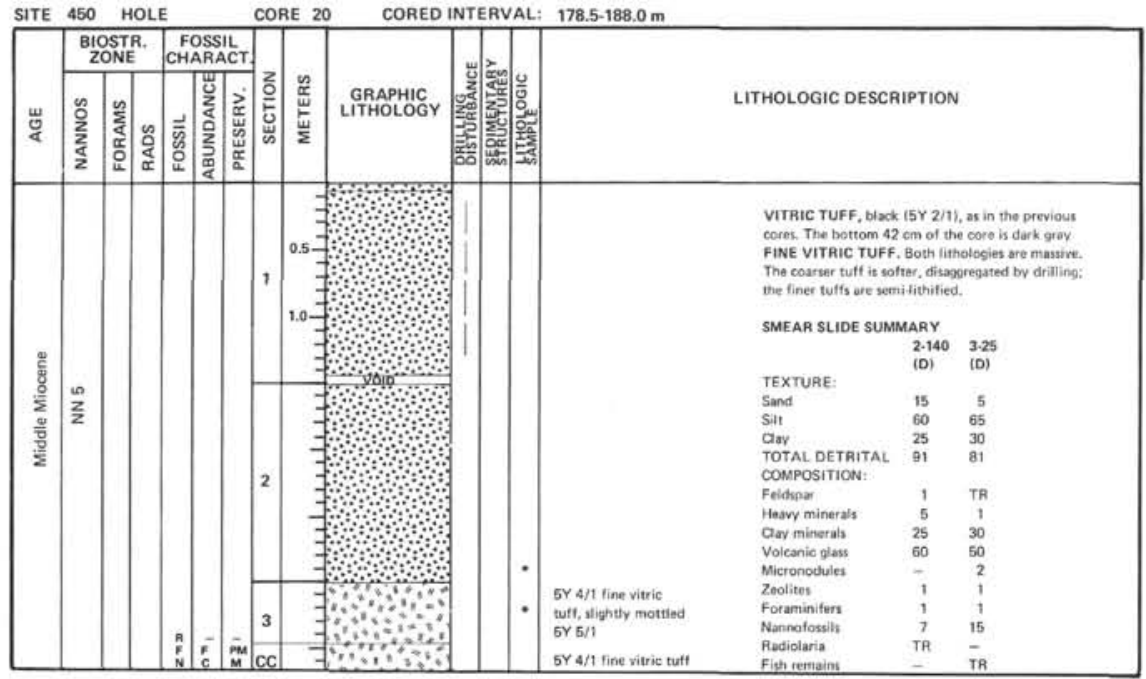



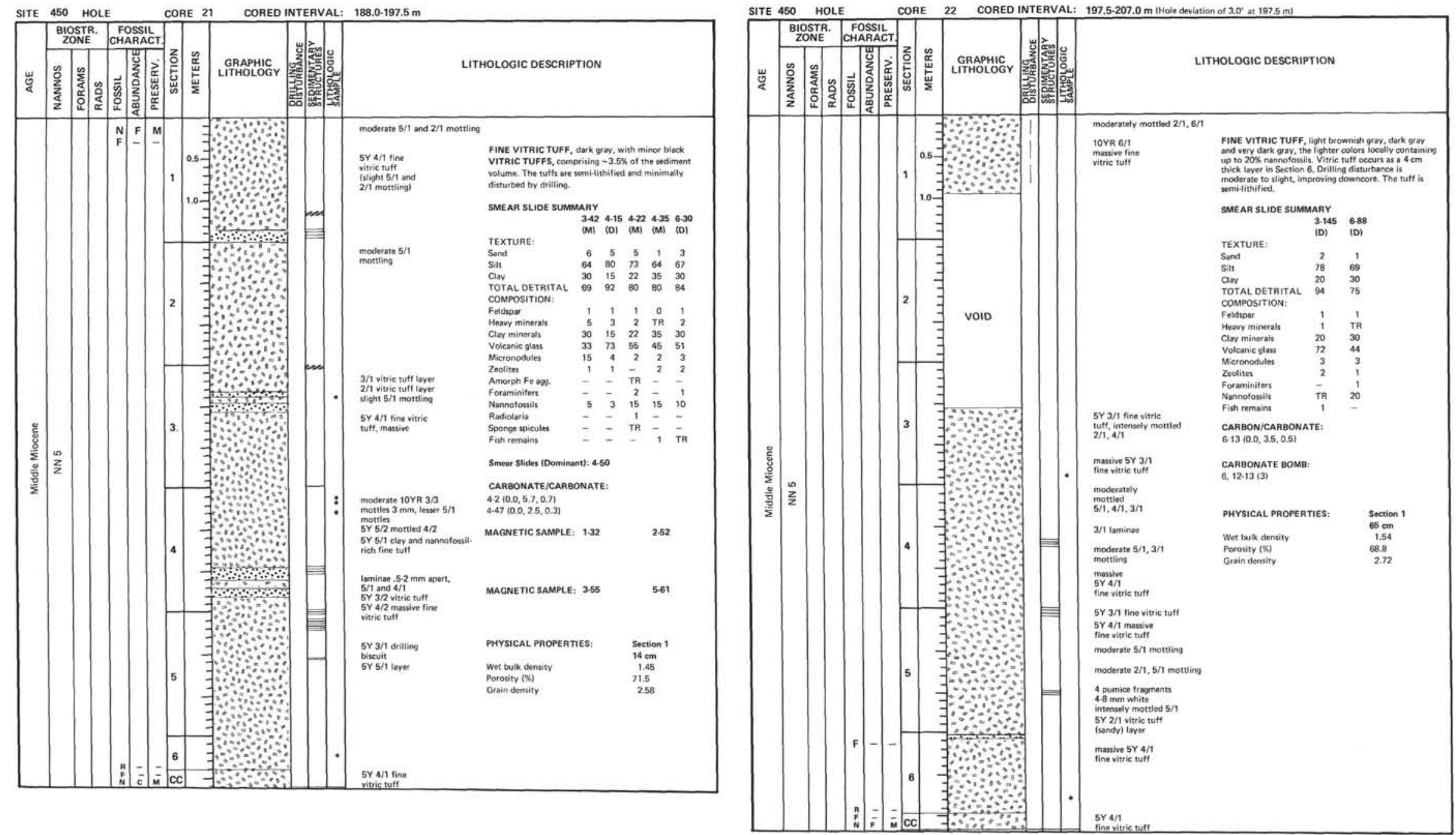
SITE 450 HOLE CORE 23 CORED INTERVAL: $207.0-216.5 \mathrm{~m}$

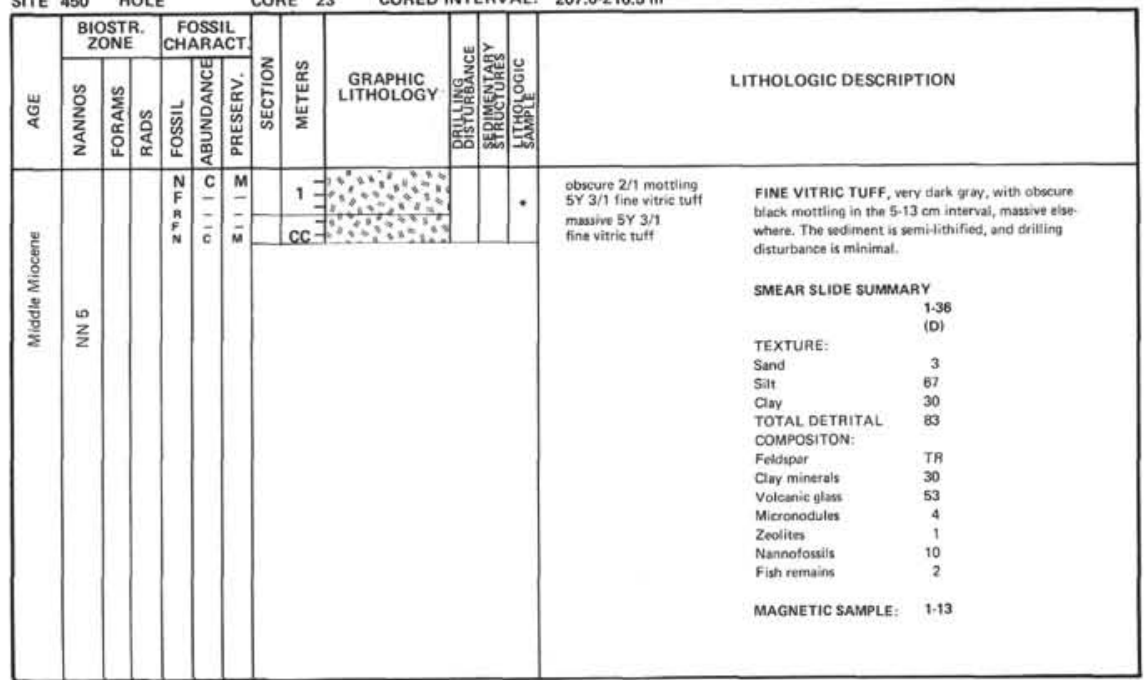

SITE 450 HOLE CORE 24 CORED INTERVAL: $216.5-226.0 \mathrm{~m}$

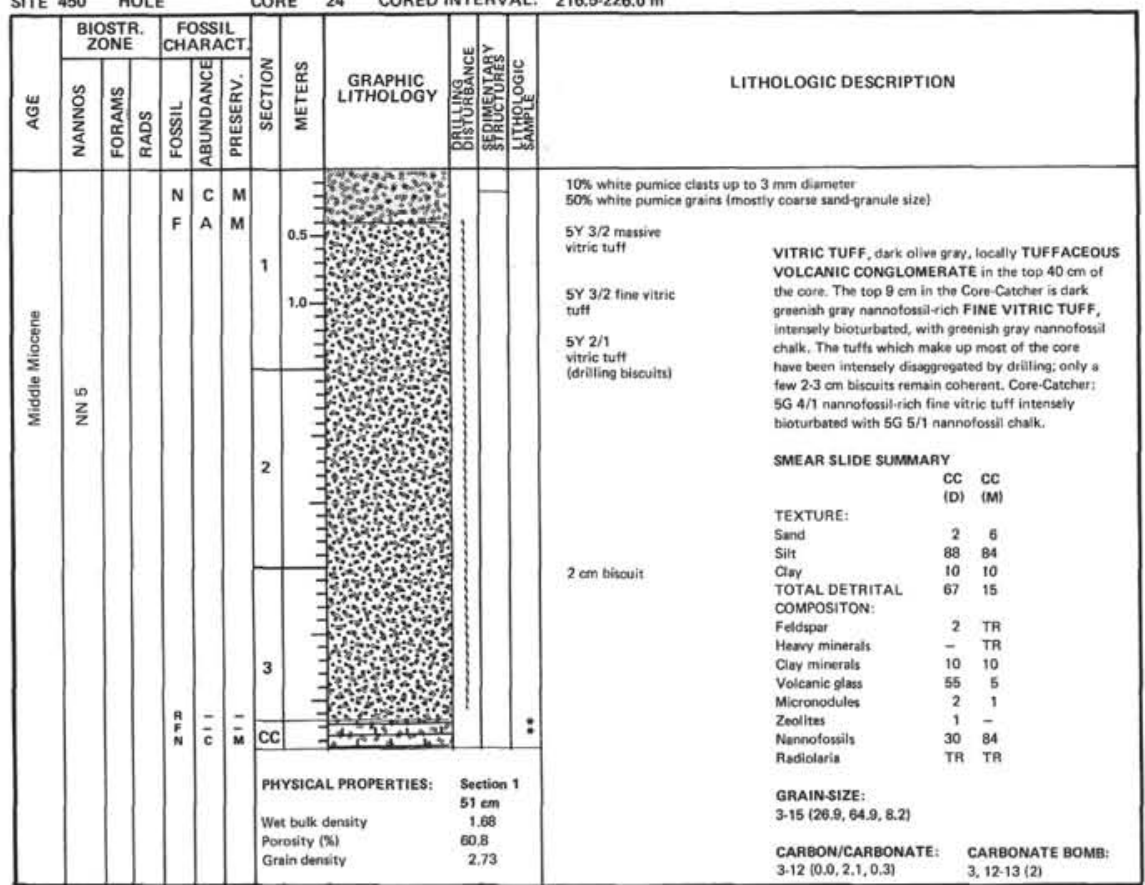

SITE 450 HOLE CORE 25 CORED INTERVAL: $226.0 .235 .5 \mathrm{~m}$

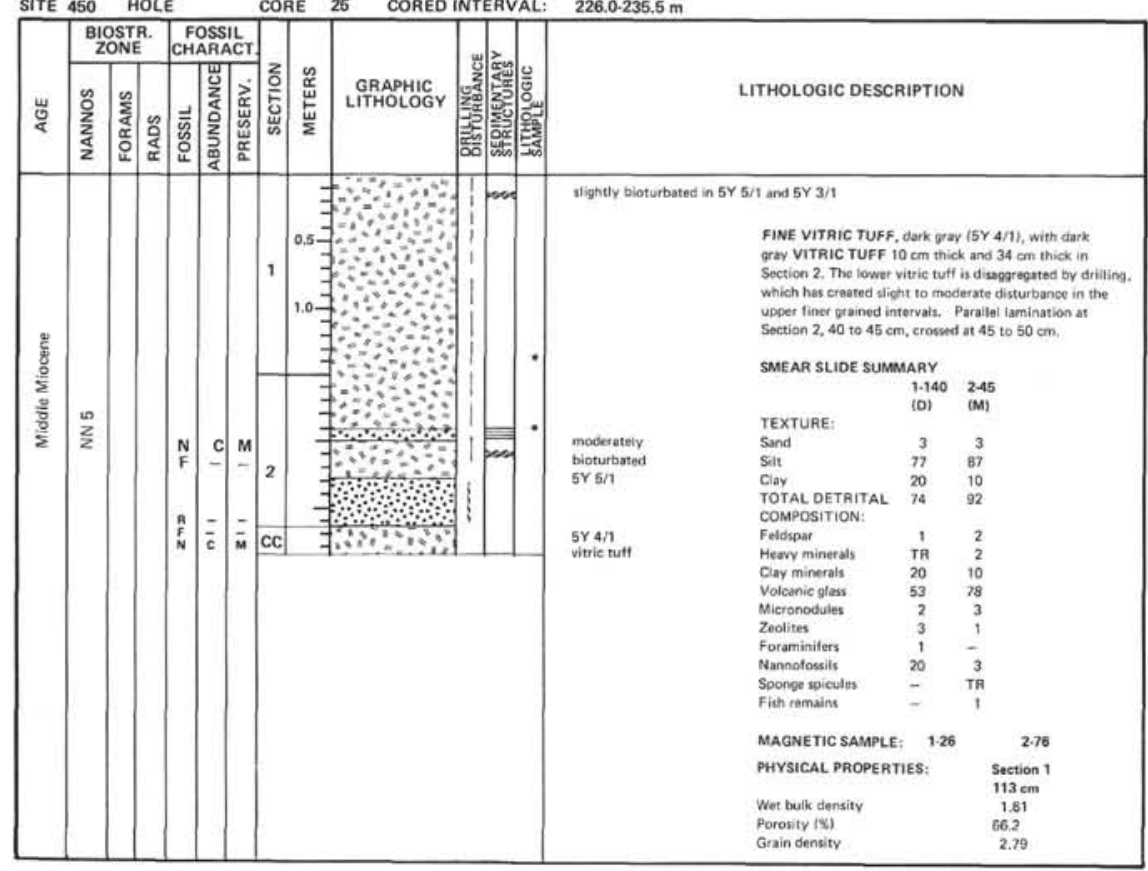

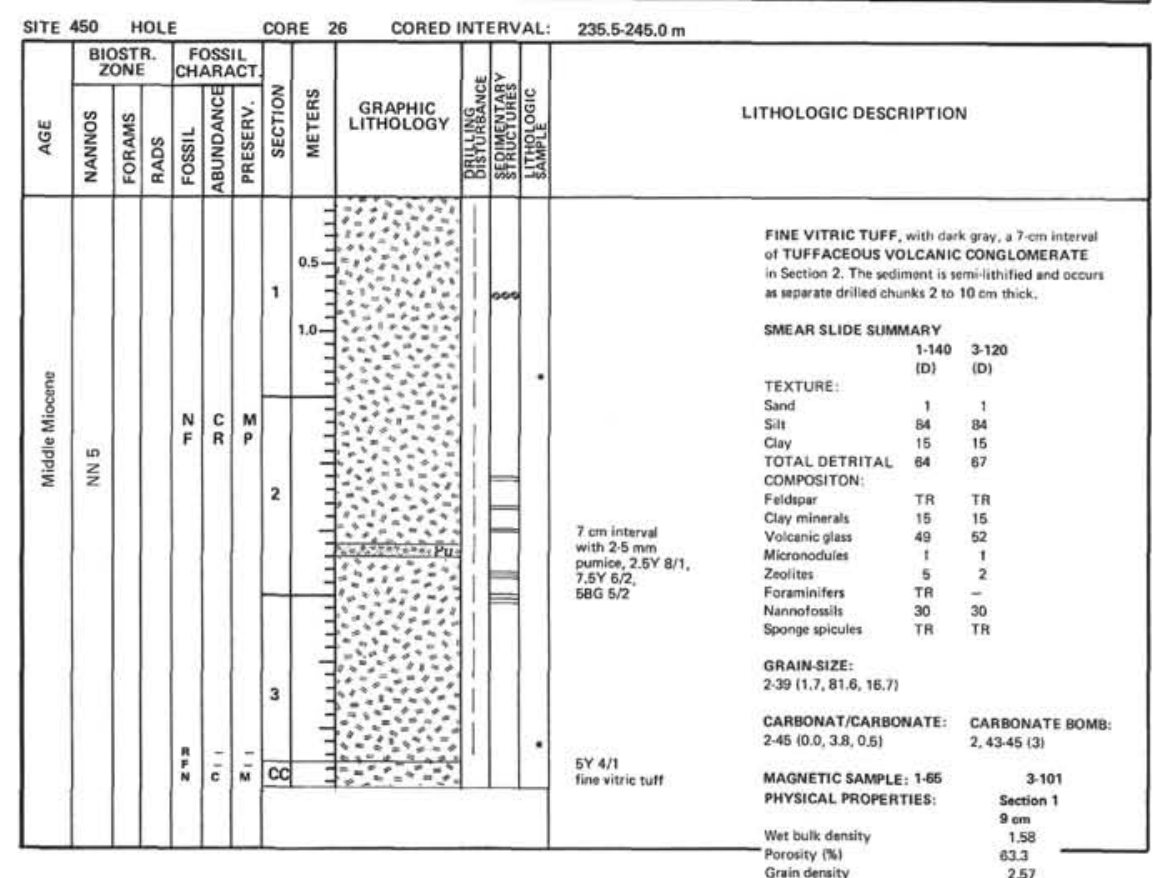




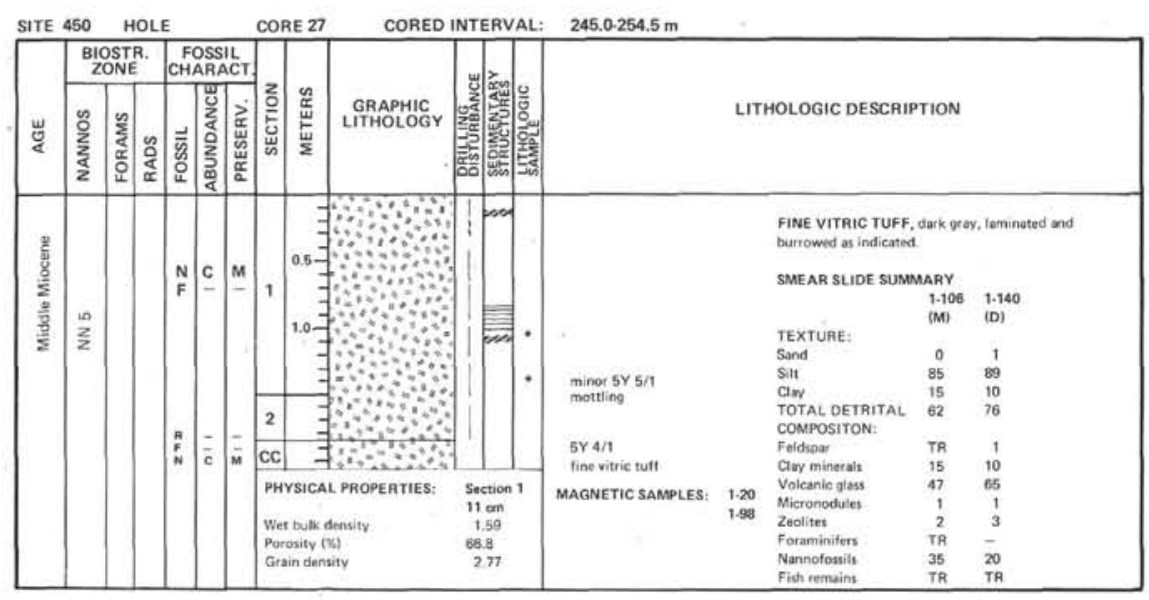

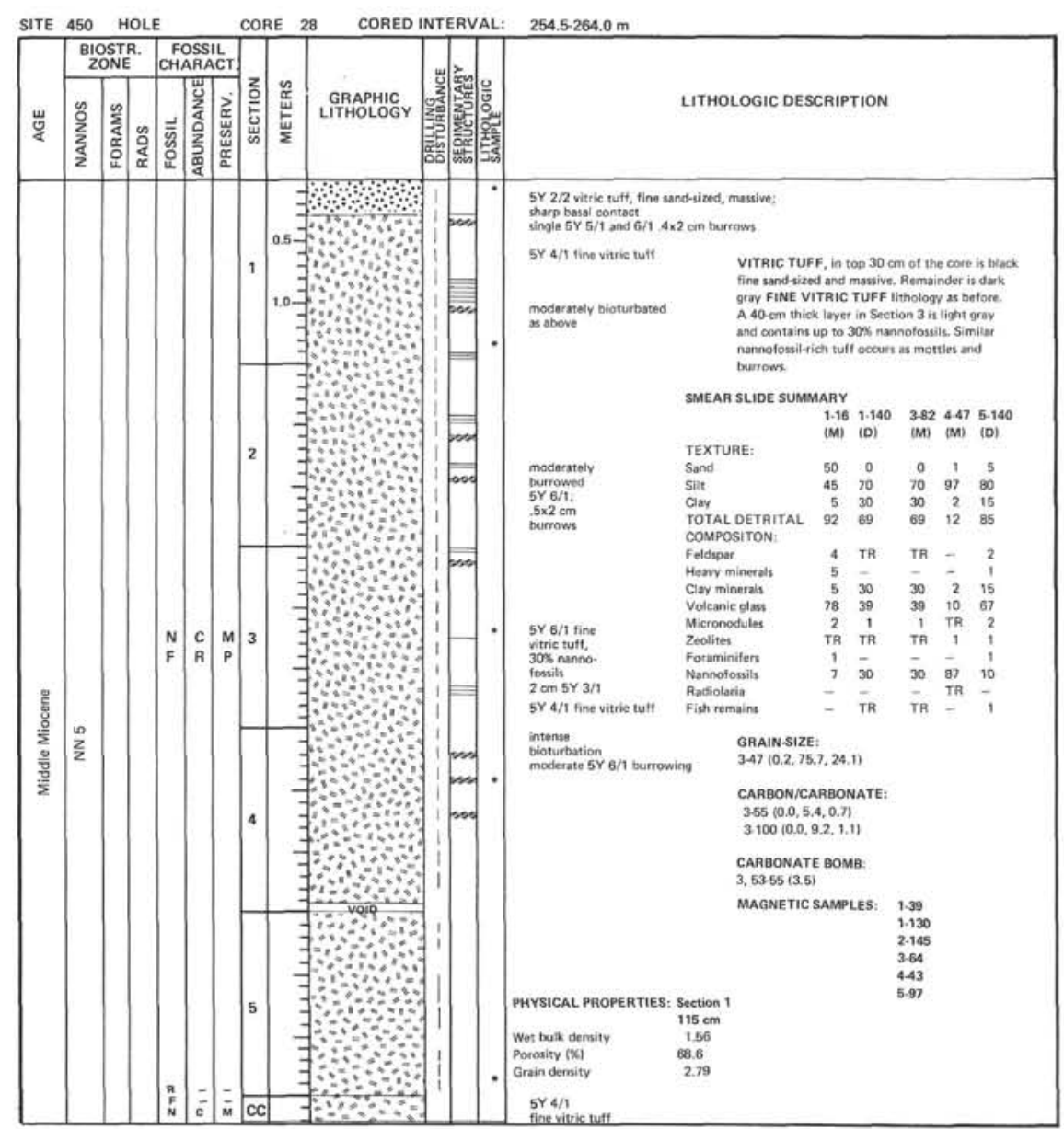



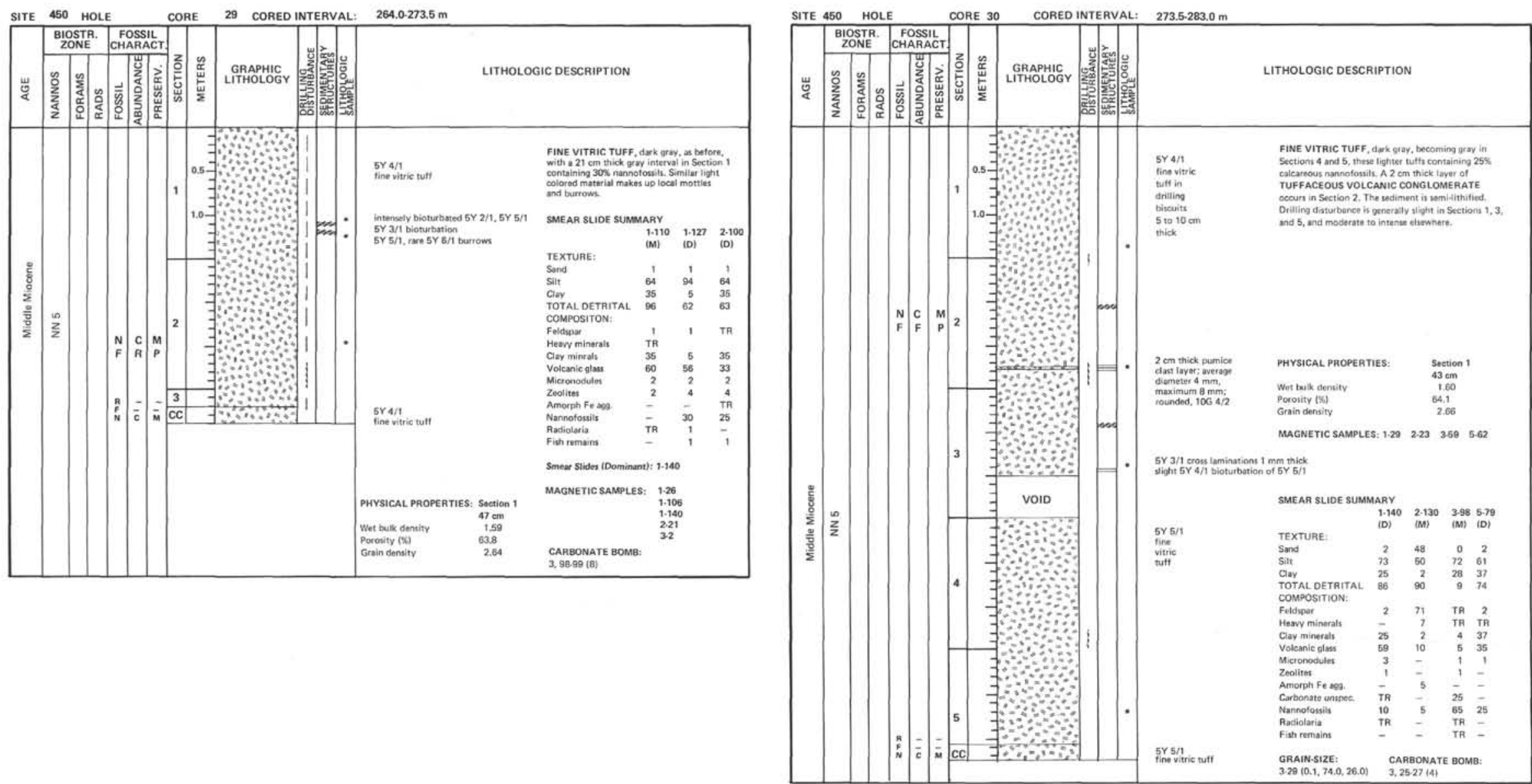


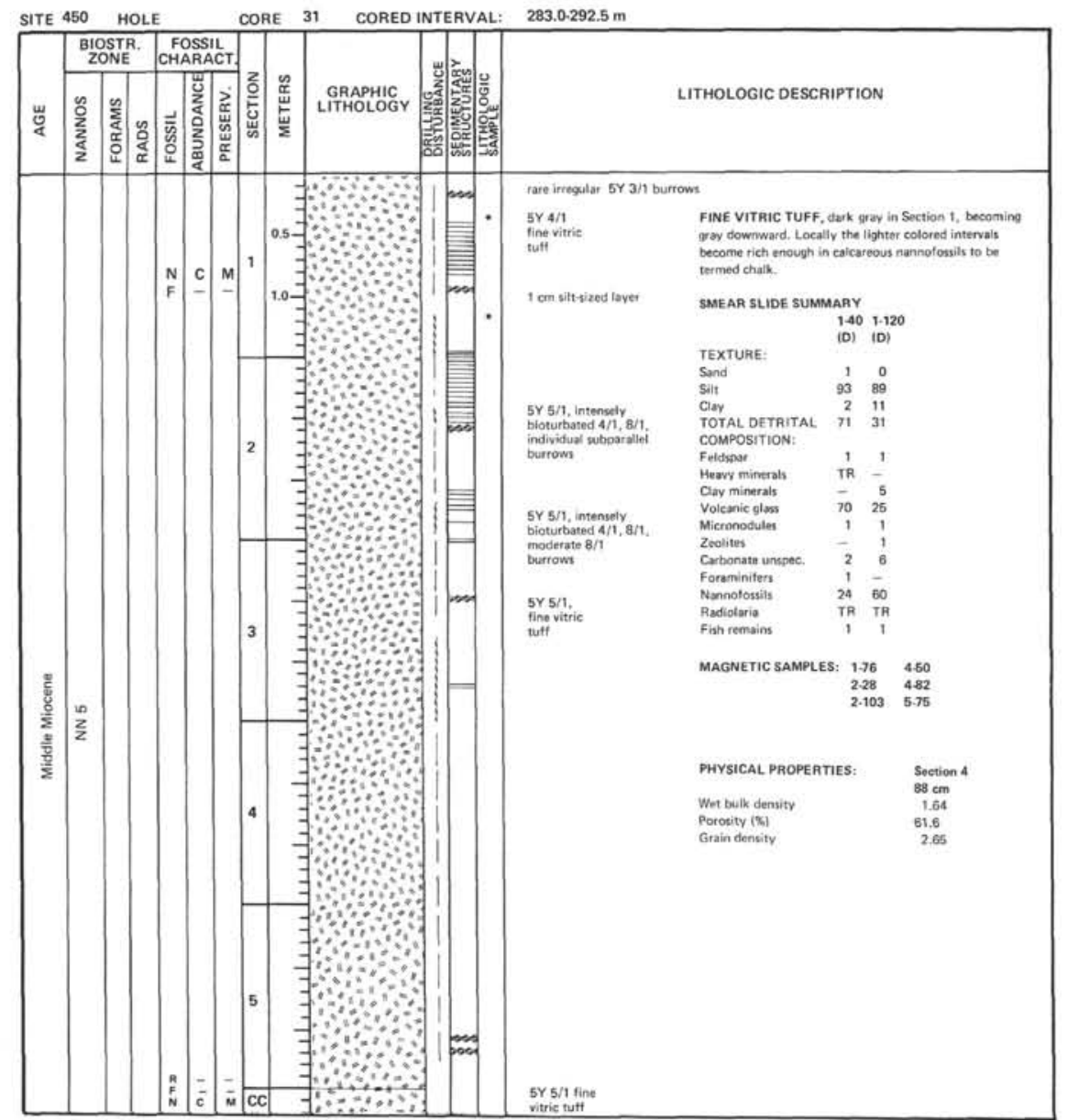

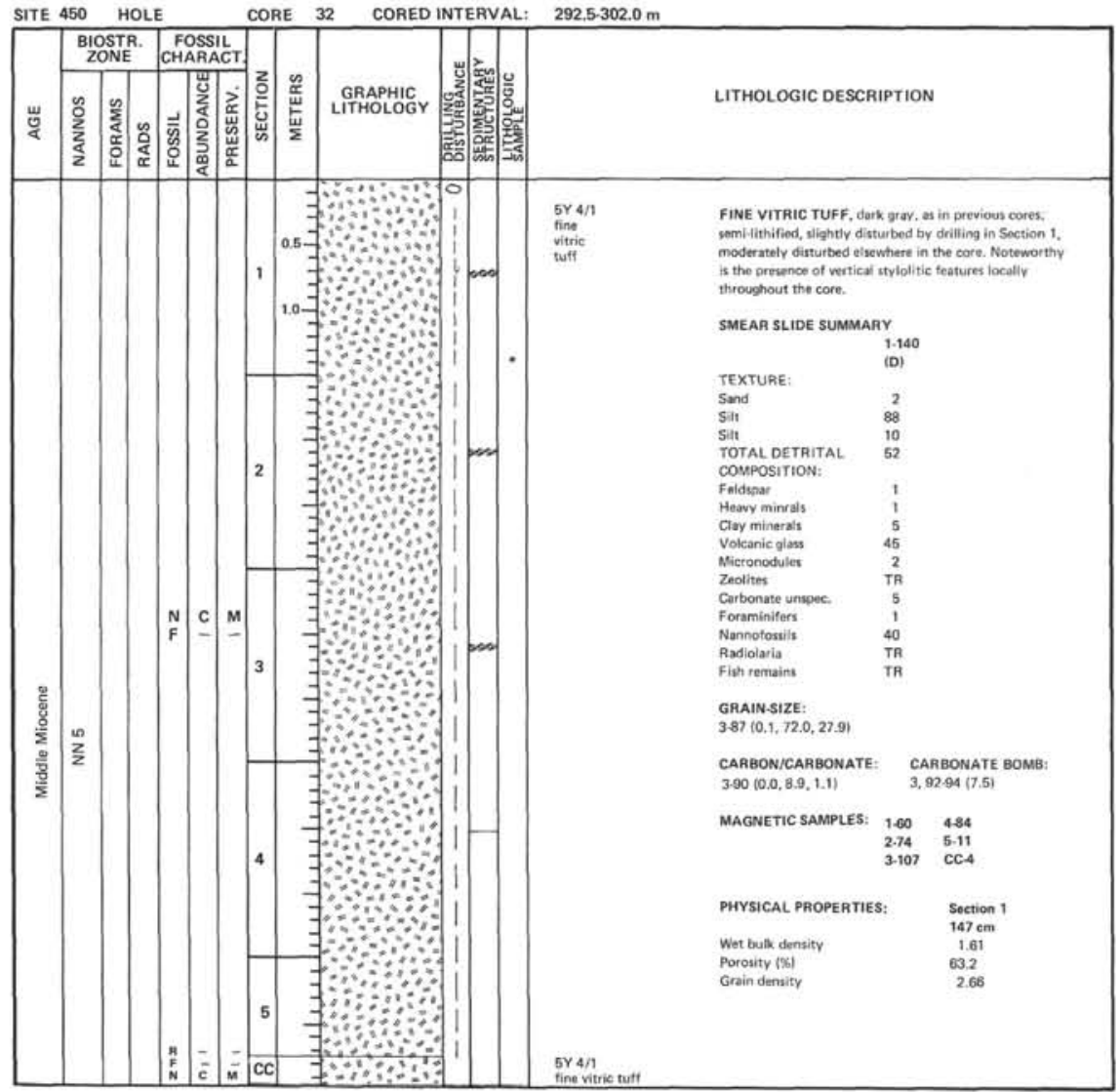




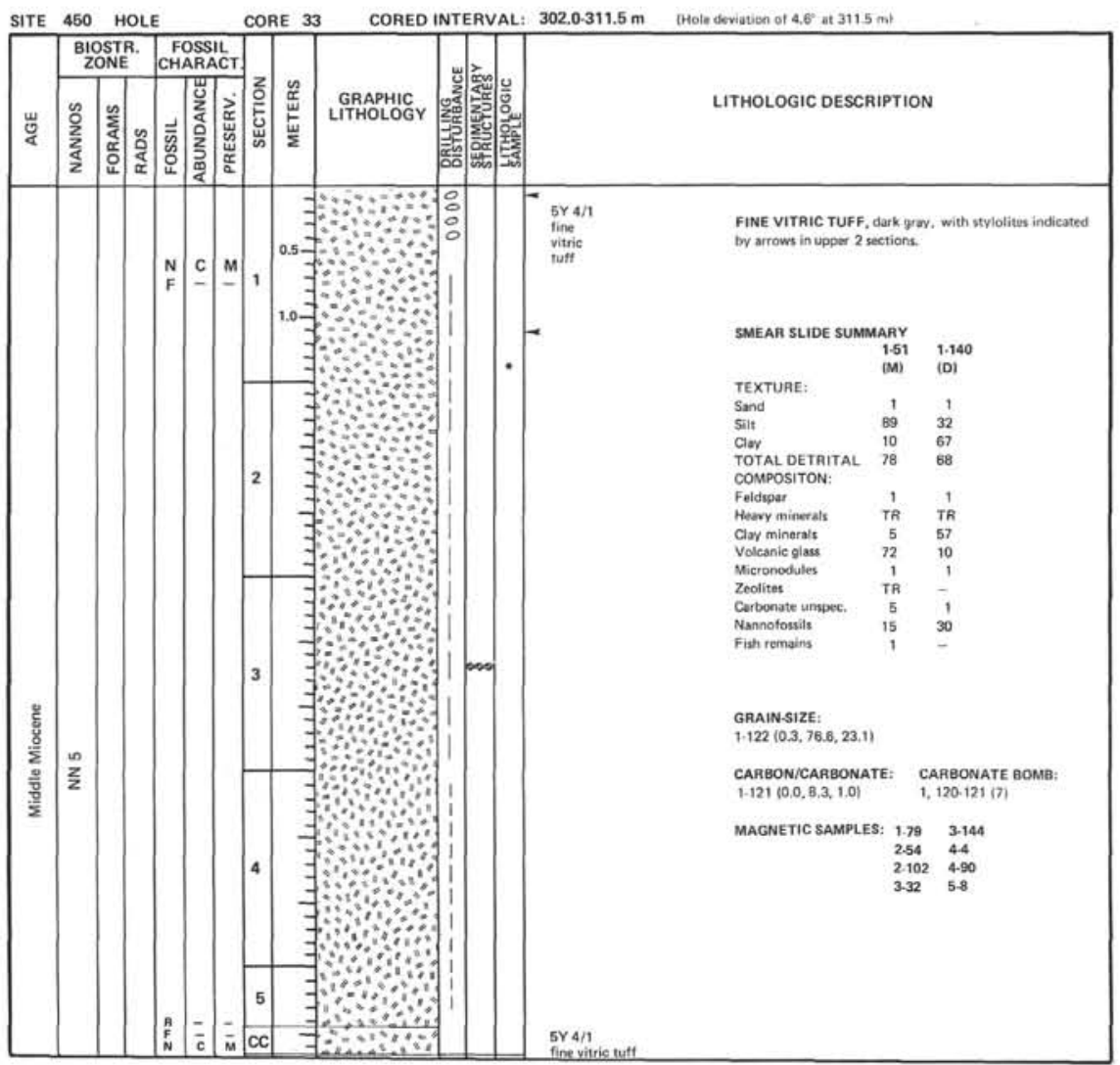

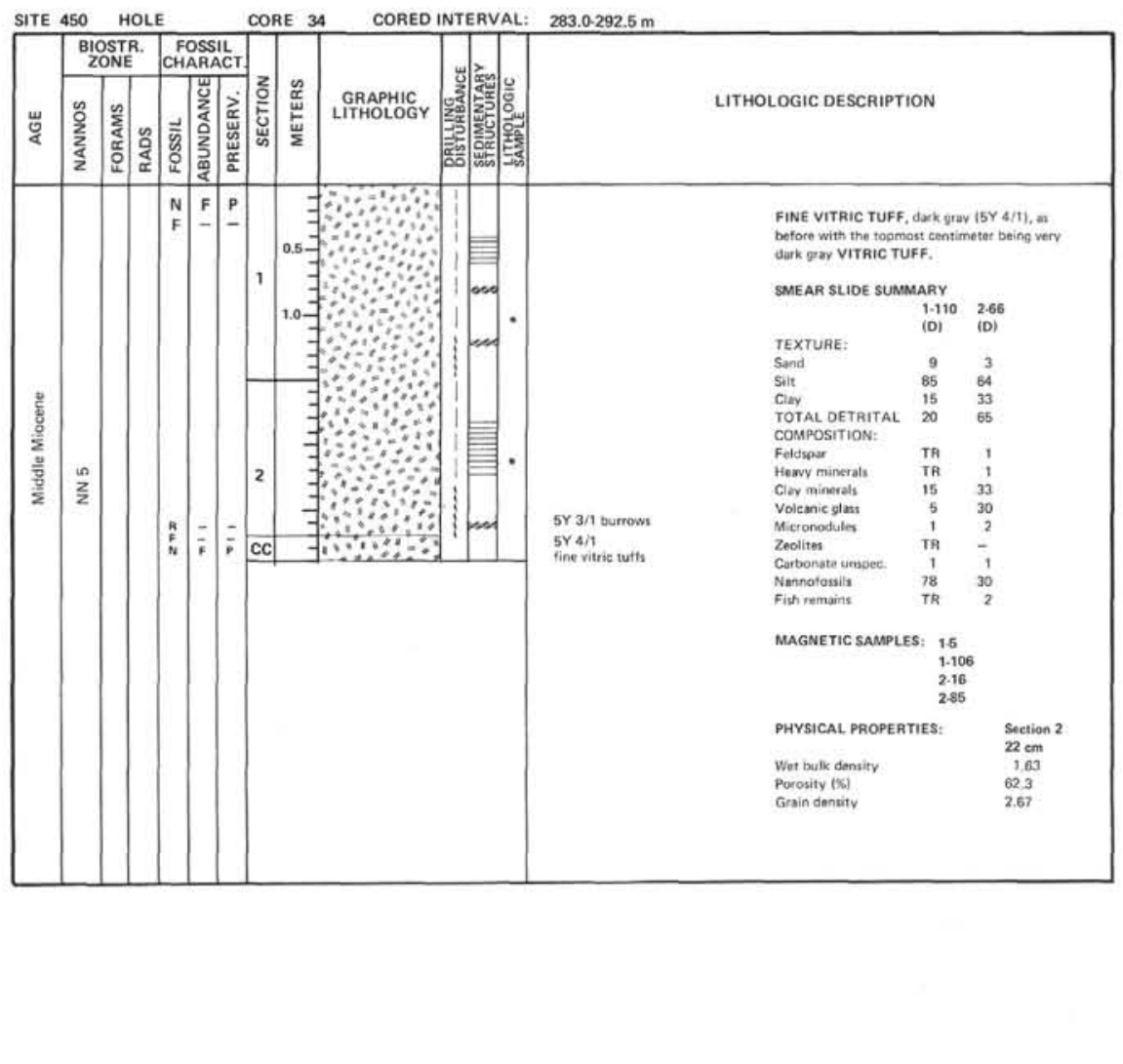




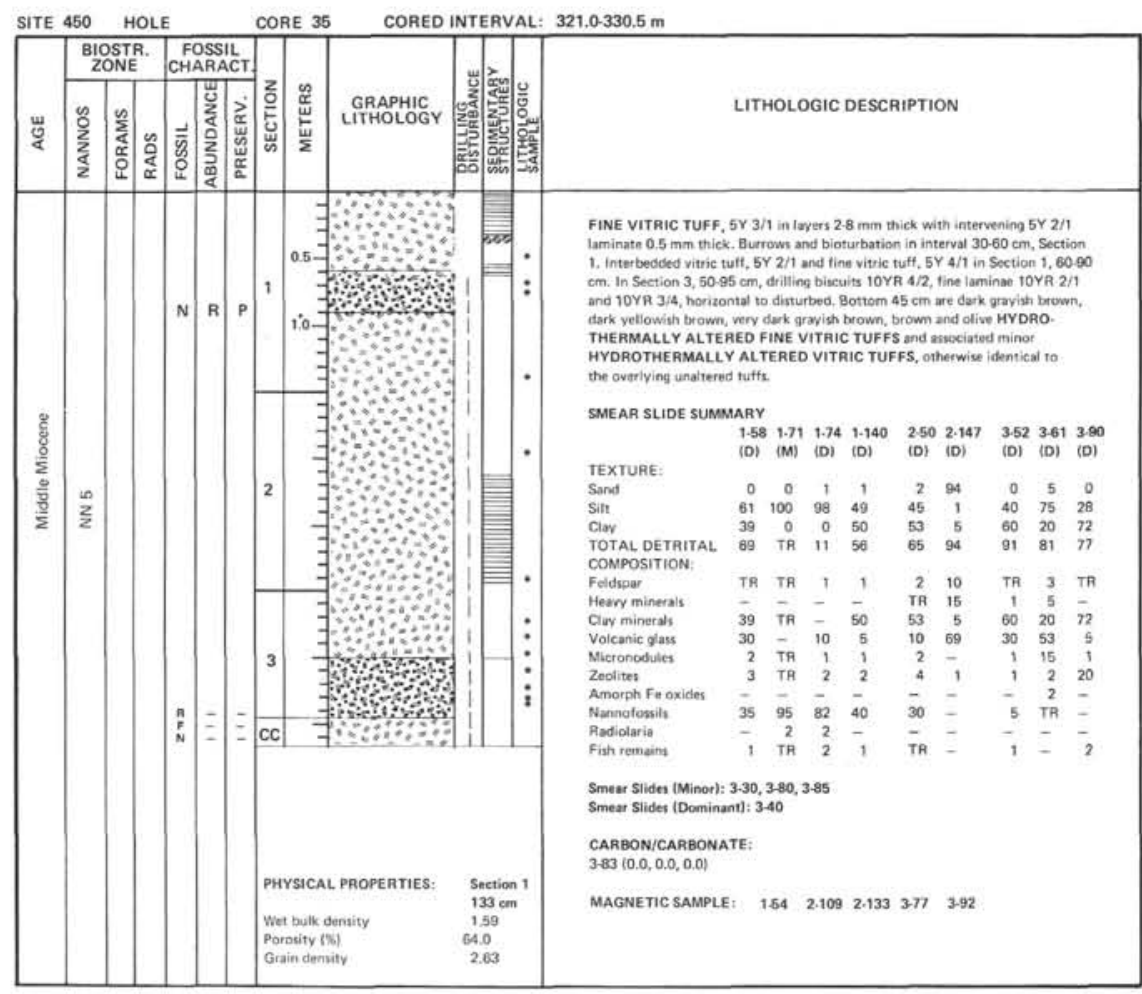

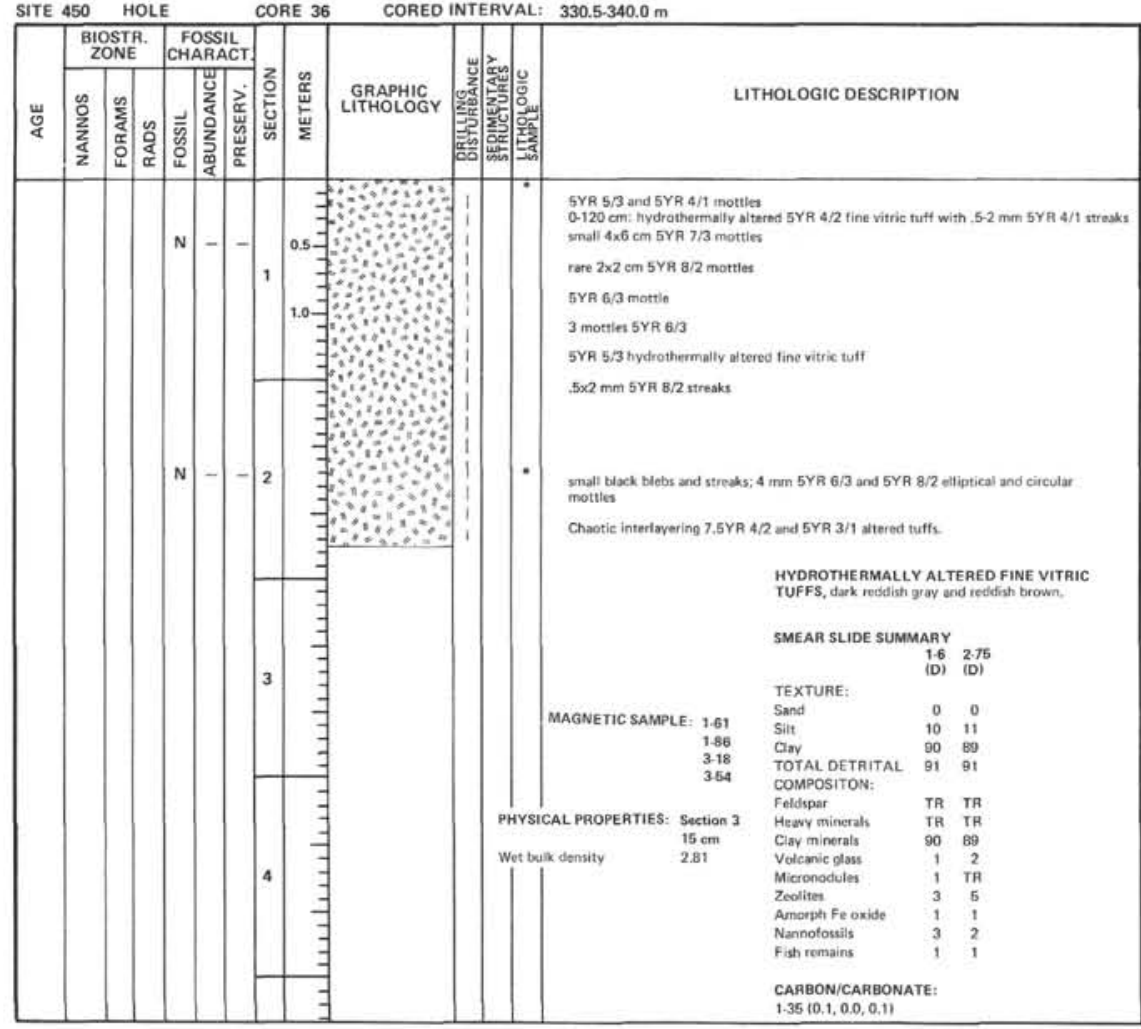




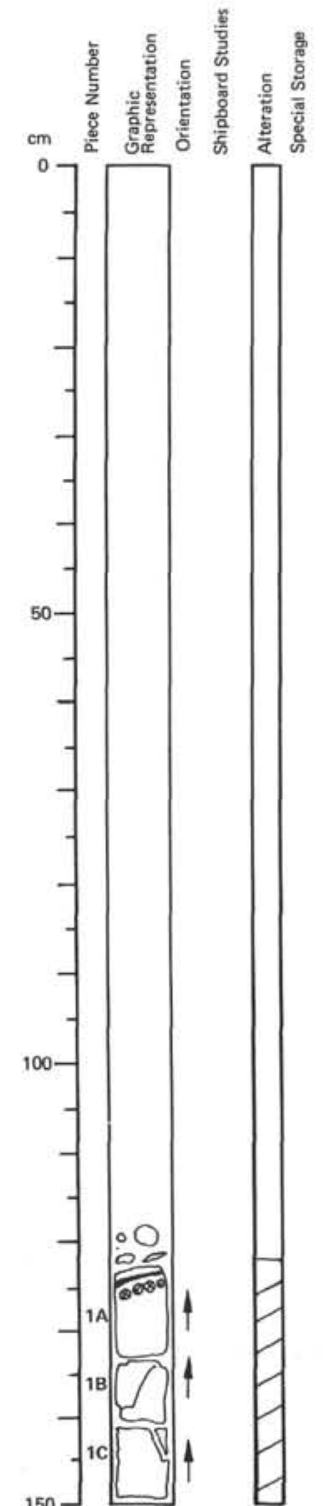
VISUAL CORE DESCRIPTION
FOR IGNEOUS ROCKS

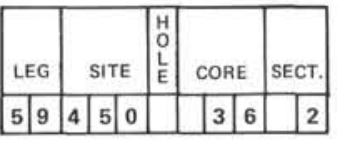

Depth: 332.0 to $333.5 \mathrm{~m}$

Visual Description

Plagiociase-clinopyroxene-olivine-phyric basalt, pillowed lava intrusive basalt. Plagioclase eunedral and in giomerocrysts. Olivine anhedral groundmass with quenched texture, thental. Vesicles $55 \%$, thed with calcite, zeolites and smectite. Topmost basalt

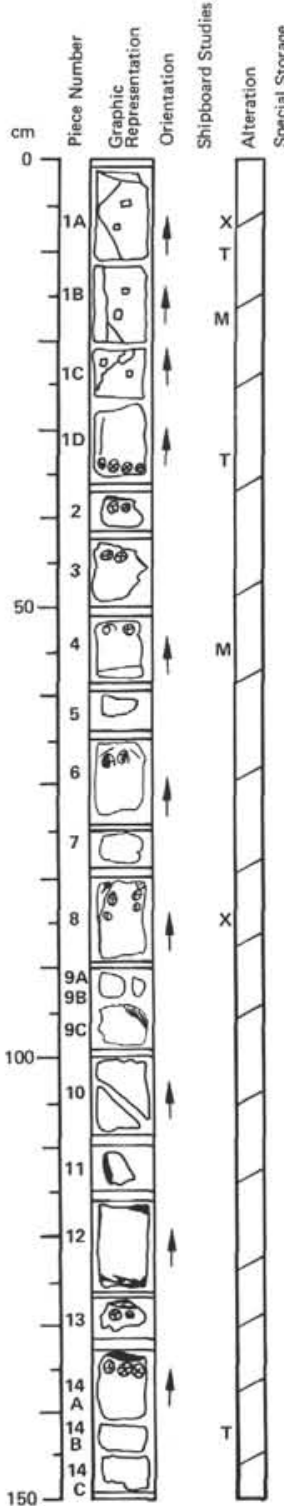

VISUAL CORE DESCRIPTION OR IGNEOUS ROCKS

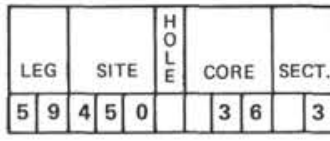

Depth: 333.5 to $335.0 \mathrm{~m}$

Visual Description

Plagioclase-clinopy

Thin Section Description

Texture: hyalopilitic

Phenocrysts: $10 \%$; plagioclase $90 \%, 1.4 \mathrm{~mm}$, euhedral, glomeromornhic, unzoned with glass

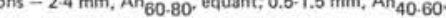
laths: olivine $10 \%, 0.2 \cdot 0.5 \mathrm{~mm}$, euhedral pseudomorphs altered to iddingsite and smetice

clidmass: $>85 \%$; plagioclase $35 \%, 0.2-0.4 \mathrm{~mm}$, An 50 , quenched skeletal crystal Vesicles: $2 \%, 0.1 \cdot 0.5 \%$, spheroidal, filled Alteration: $5 \%$ altered glass

Thin Section Description

Lcation: $31.35 \mathrm{~cm}$, next to glassy margin

Phenocrysts: $10 \%$; plagioclase $85 \%, 0.5 \cdot 2 \mathrm{~mm}$, An -70 . 20ned, partly replaced by calcite and smectite; olivine $15 \%, 0.2 .0 .5 \mathrm{~mm}$, skeletal, euhedrat, pseudomorphs

(a) to subophitic; glass $75 \%$, contains xenolith, $2 \times 5 \mathrm{~mm}$, of vitric tuff

Aiteration: clays replace glass and mafics

\section{Thin Section Description}

Location: $139.145 \mathrm{~cm}$, pillow interio

Phenocrysts: $15 \%$; mostly plagioclase $15 \%, 2.6 \mathrm{~mm}, \mathrm{An}_{60.70}$, euhedral, zoned; olivine trace, $0.2 \mathrm{~mm}$ Subnedrat, replaced by clays

(a) . Vesictes: $2 \%, 0.20 .5 \mathrm{~mm}$, filled with green smectite, calcite, zeolites Alteration: $<10 \%$, clays replacing glass

$\begin{array}{lcc}\text { Shipboard Data } & & \\ \mathrm{Bull}^{2} \text { Analysis: } & 7 \mathrm{~cm} & 86 \mathrm{~cm} \\ \mathrm{SiO}_{2} & 50.0 & 49.6 \\ \mathrm{TiO}_{2} & 1.43 & 1.35 \\ \mathrm{Al}_{2} \mathrm{O}_{3} & 15.2 & 15.4 \\ \mathrm{Fe}_{2} \mathrm{O}_{3} & 1.09 & 1.12 \\ \mathrm{FeO}^{20} & 7.22 & 7.37 \\ \mathrm{MnO} & 0.17 & 0.16 \\ \mathrm{MgO} & 7.58 & 7.40 \\ \mathrm{CaO} & 13.08 & 12.99 \\ \mathrm{Na}_{2} \mathrm{O} & 2.87 & 2.71 \\ \mathrm{~K}_{2} \mathrm{O} & 0.23 & 0.37 \\ \mathrm{P}_{2} \mathrm{O}_{5} & 0.11 & 0.11 \\ \mathrm{O}_{2} \mathrm{O} & & \end{array}$




\section{Hole 450}

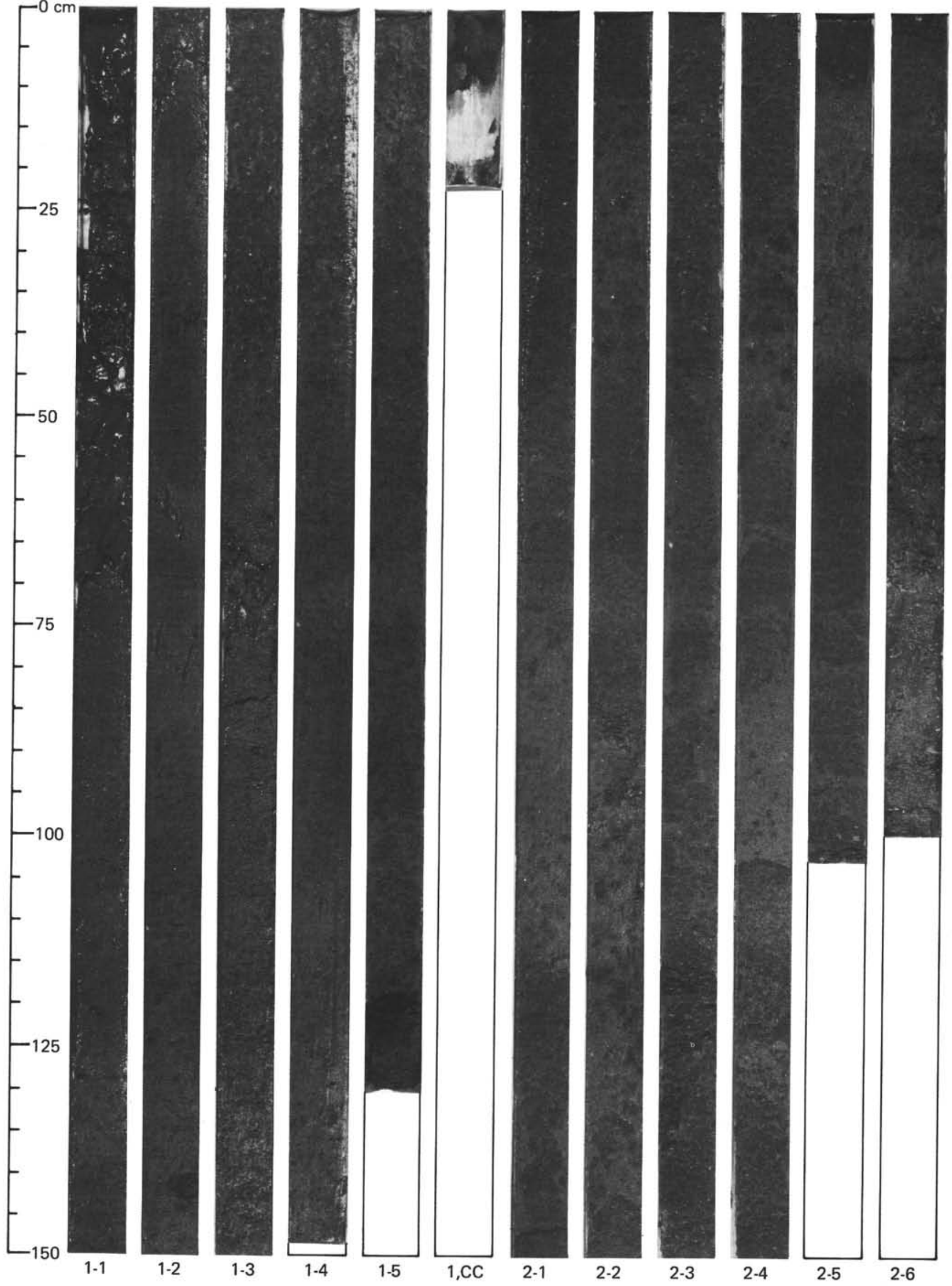


Hole 450

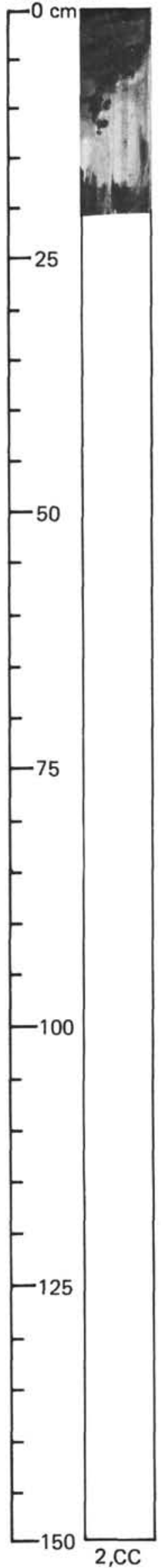

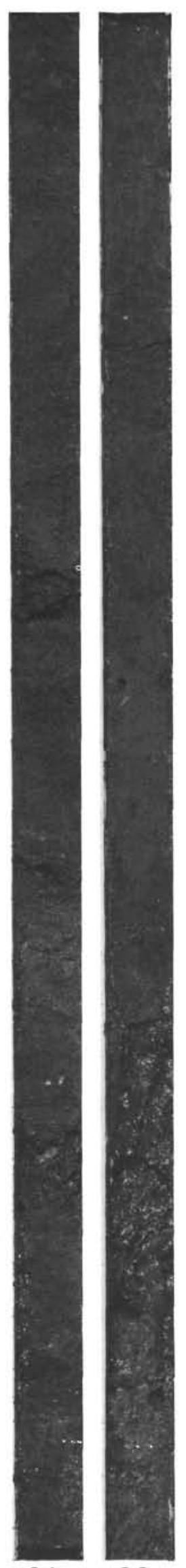

3-1
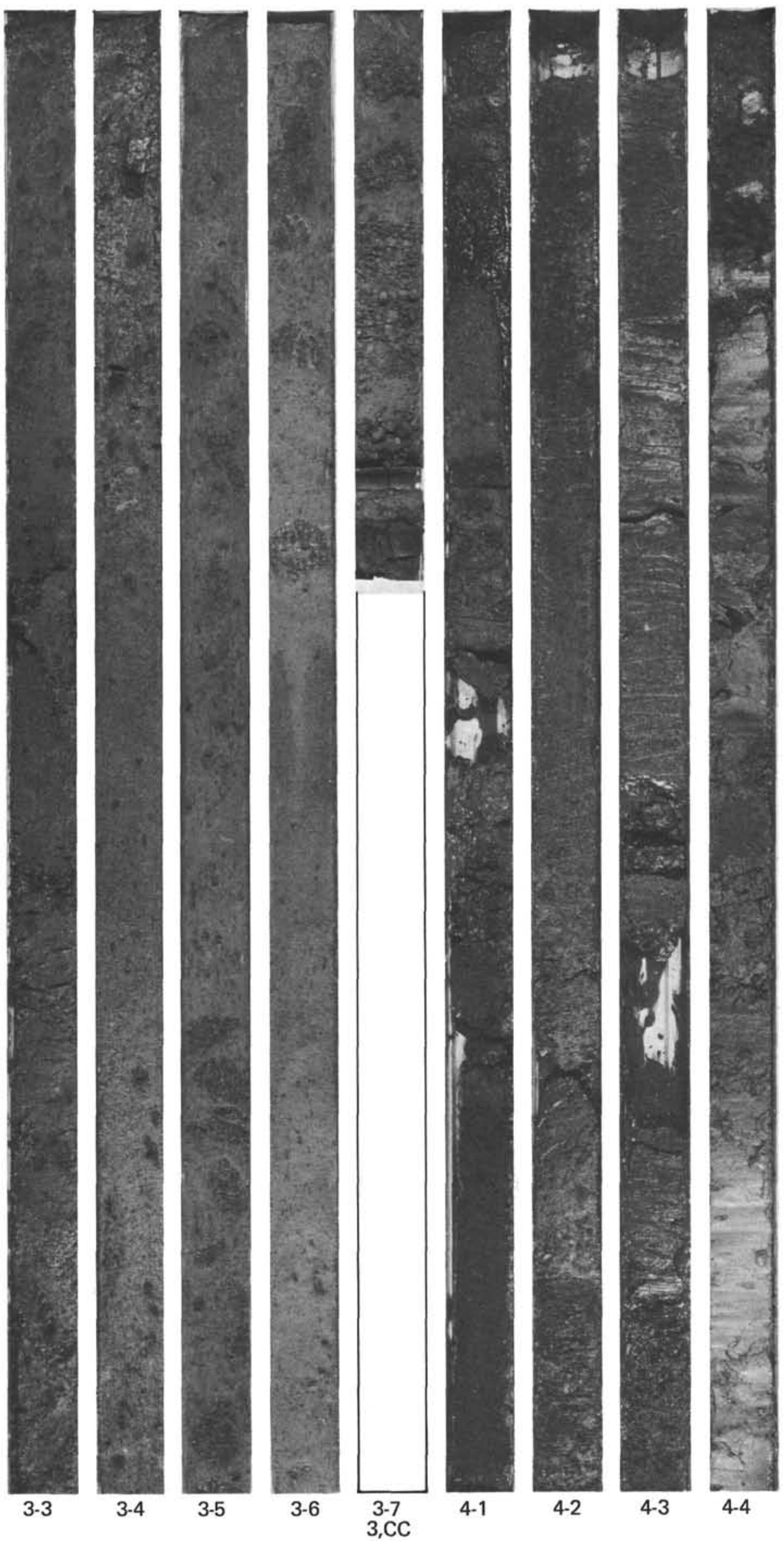
Hole 450

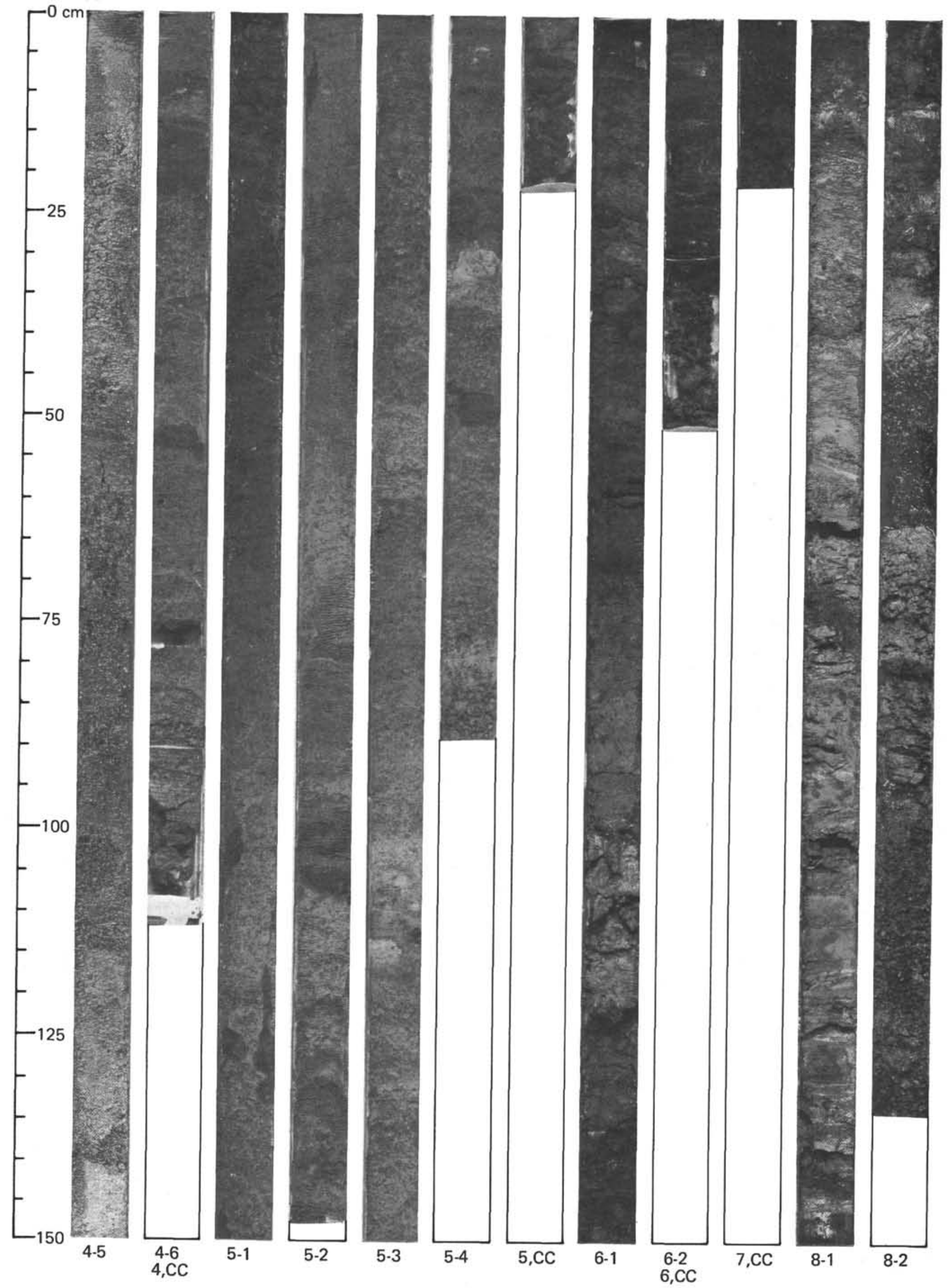




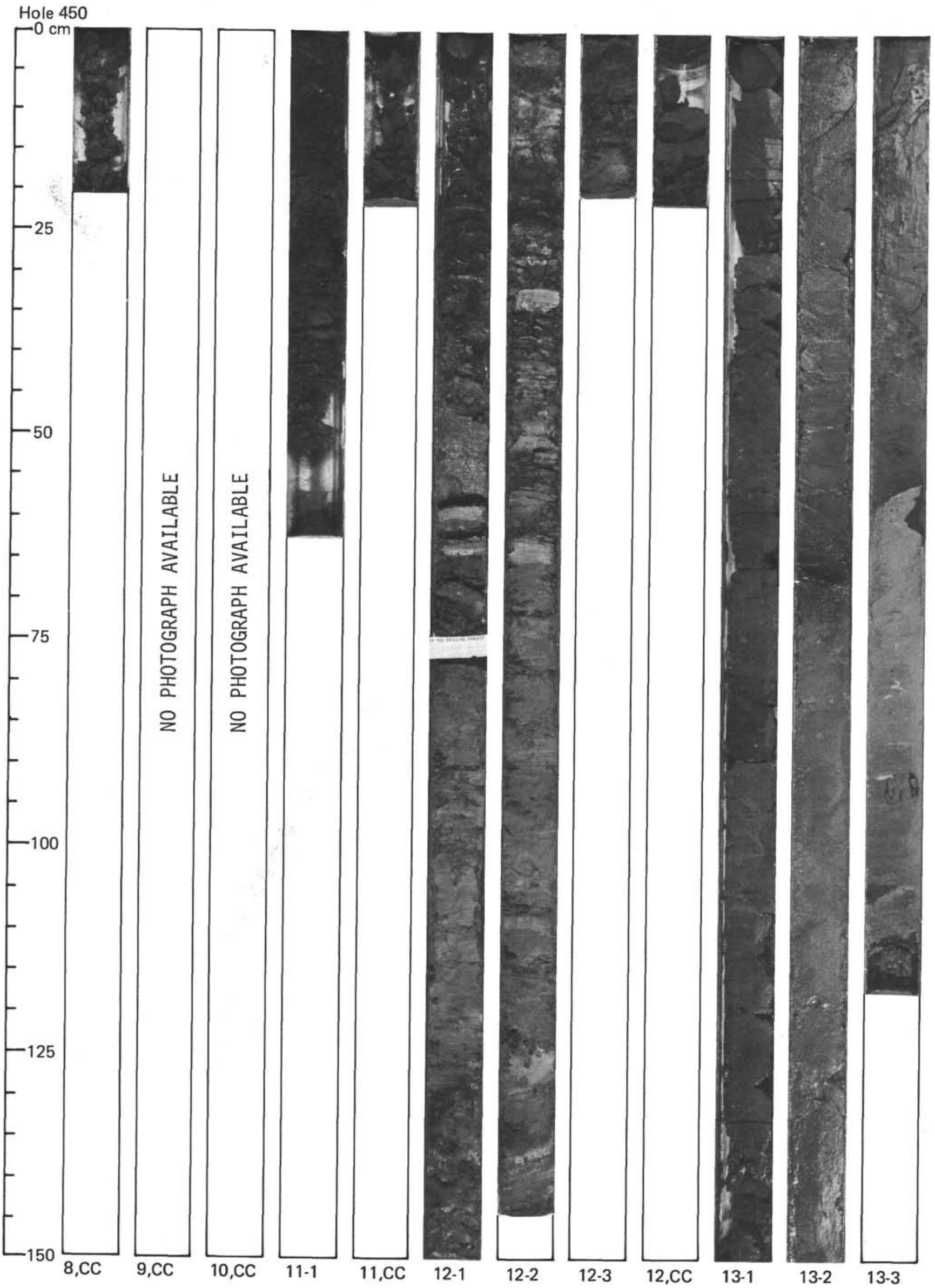


Hole 450

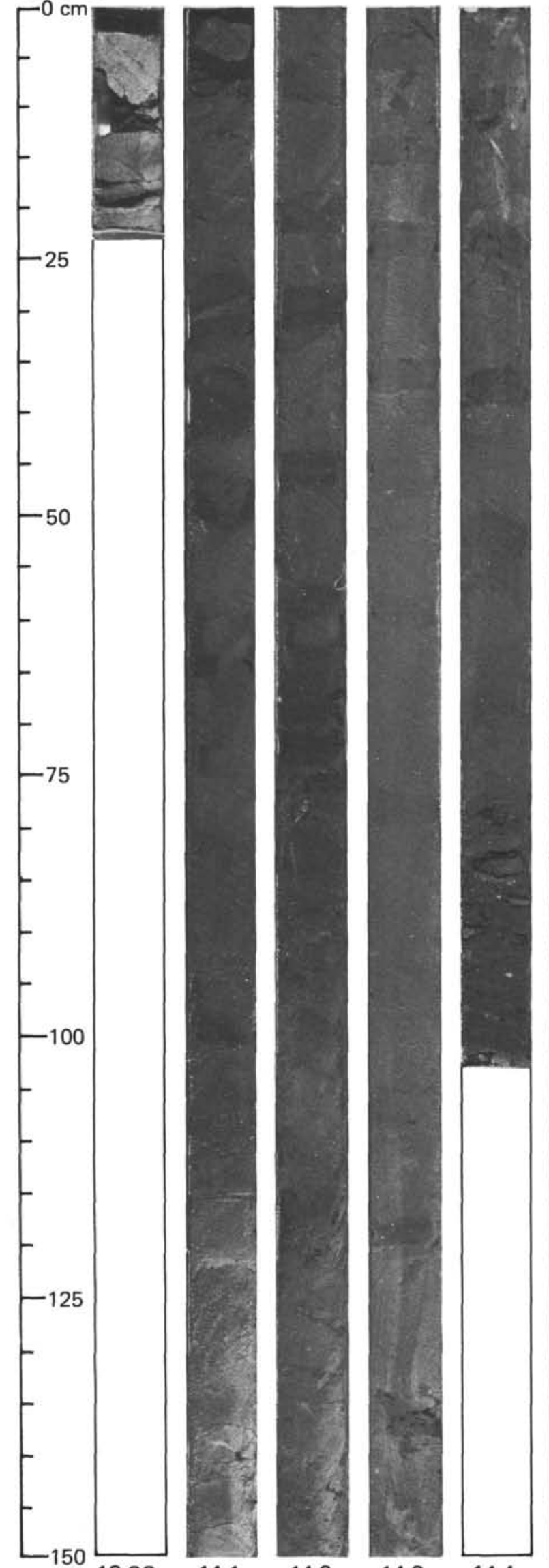

$13, \mathrm{CC}$

14-1

14-2

14-3

14-4

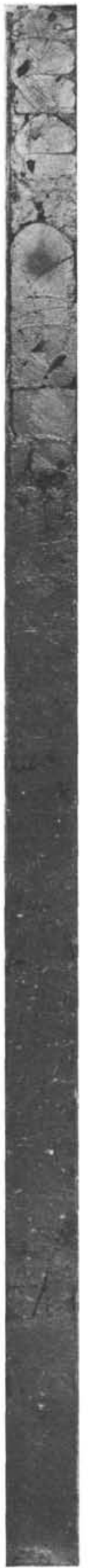

14-5

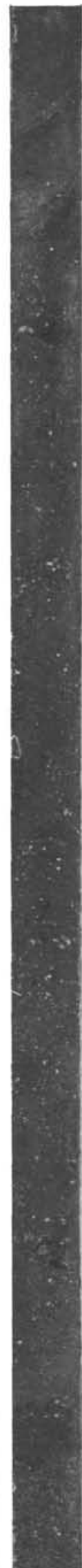

14-6
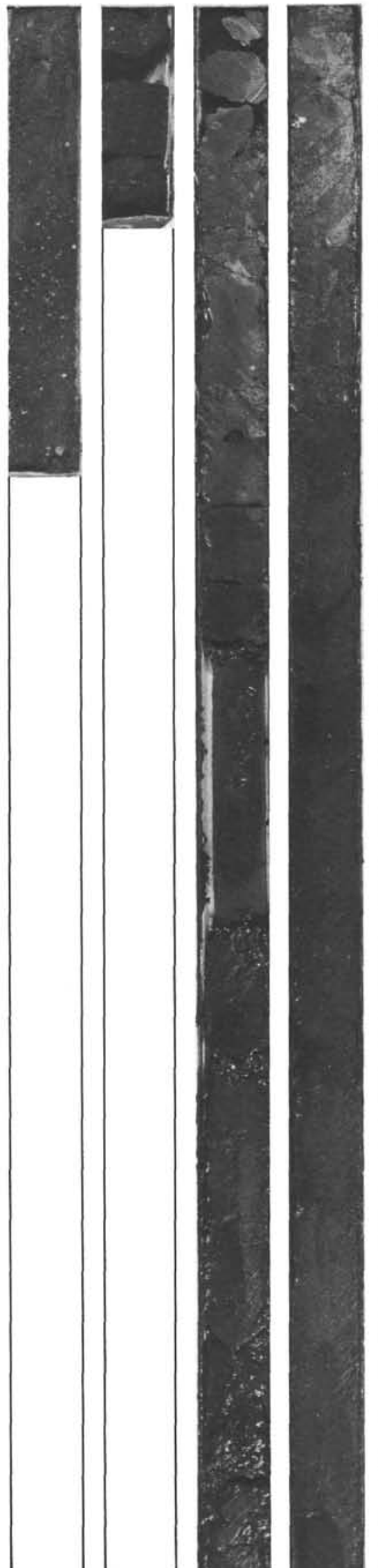

15-1 
Hole 450

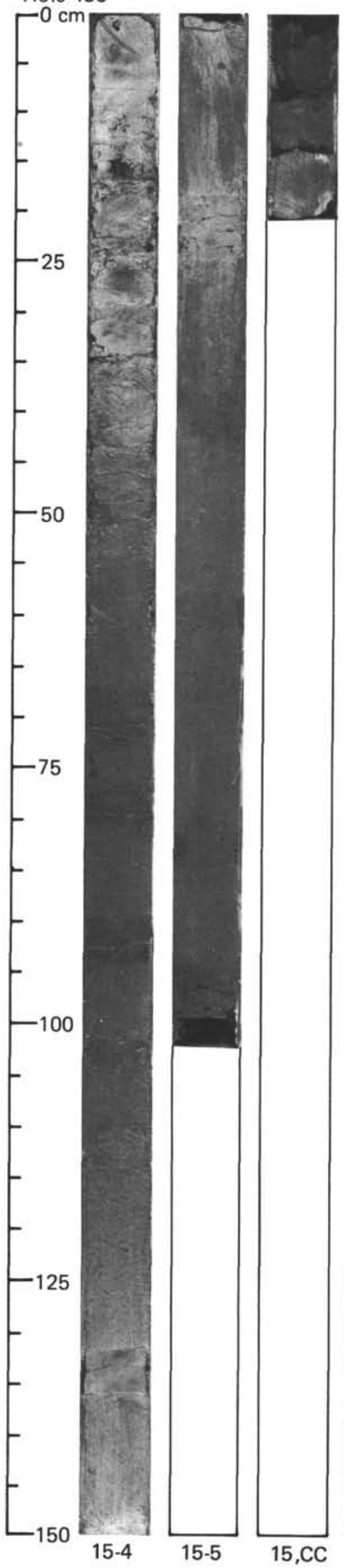

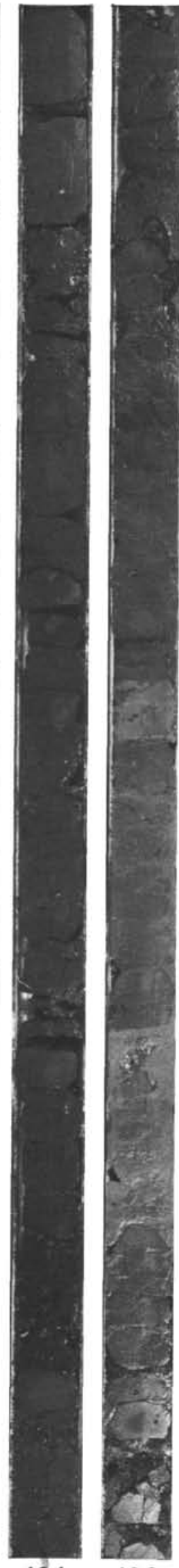

$16-1$

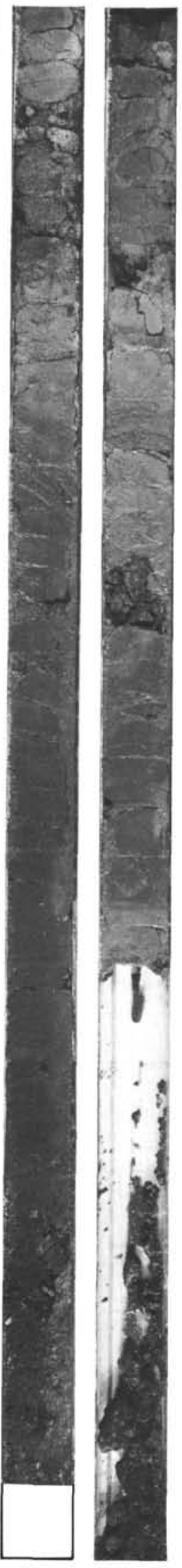

16-3

16-4
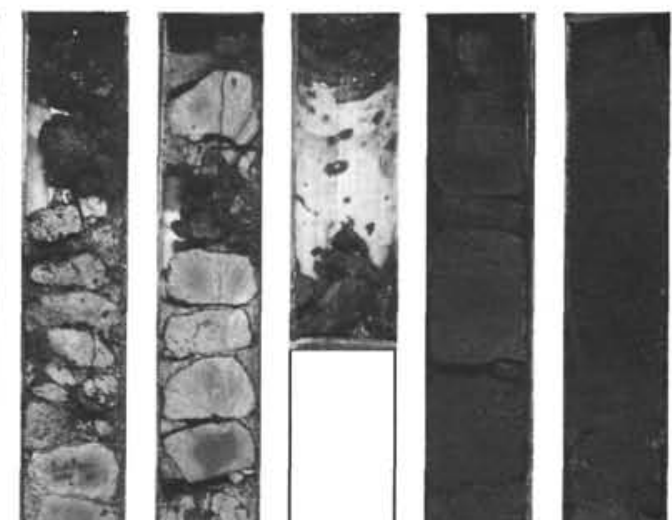

(1)
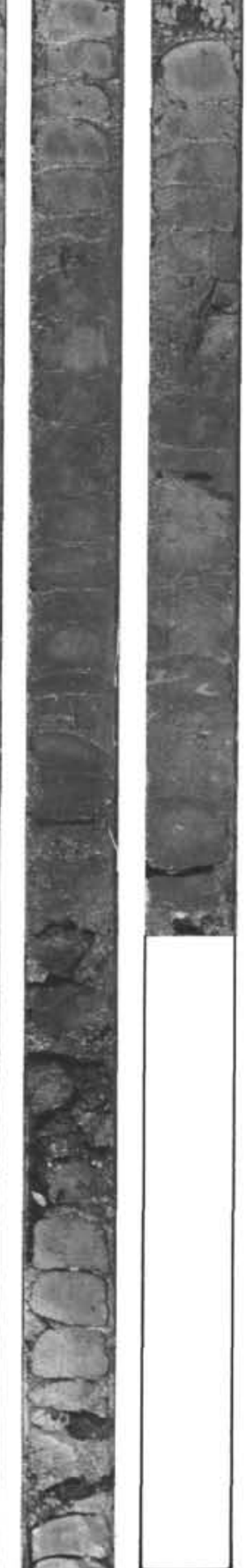

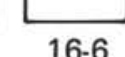




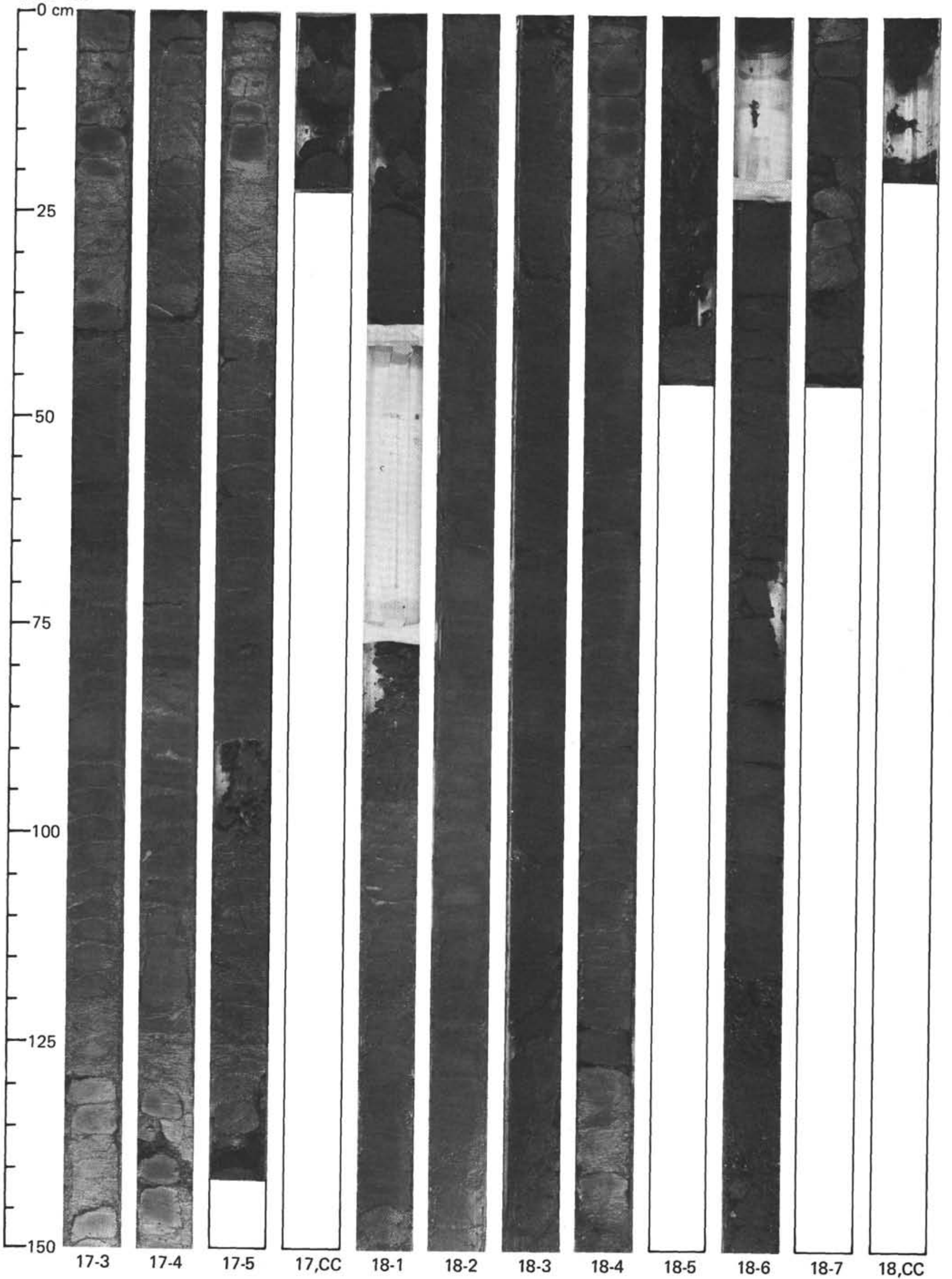


Hole 450

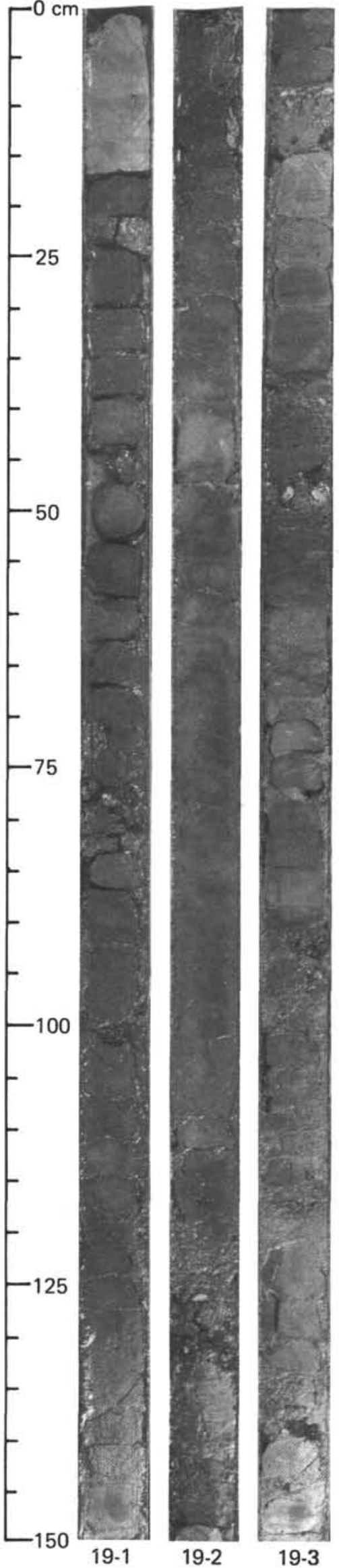

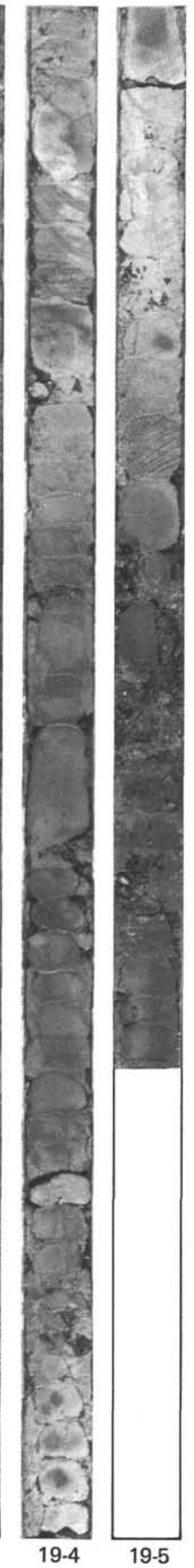
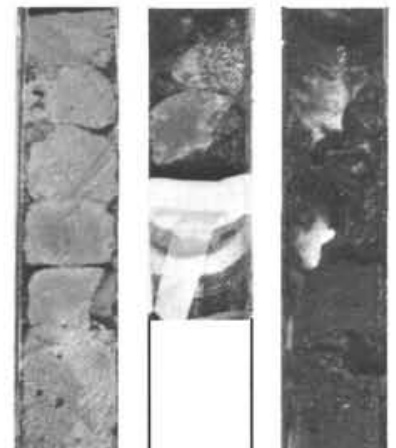

[
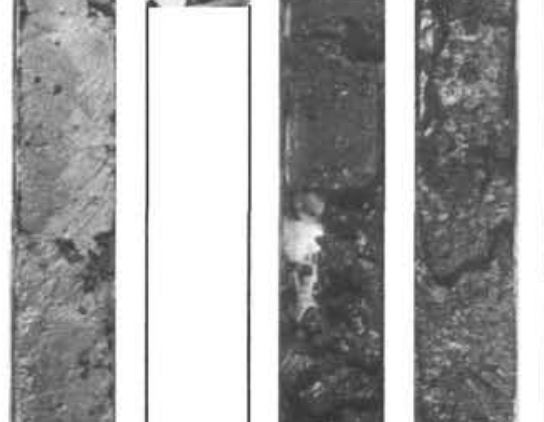$$
\text { te }
$$$$
\text { and }
$$

\section{is}

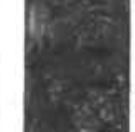

$\frac{2}{4}$

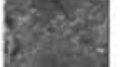

3.
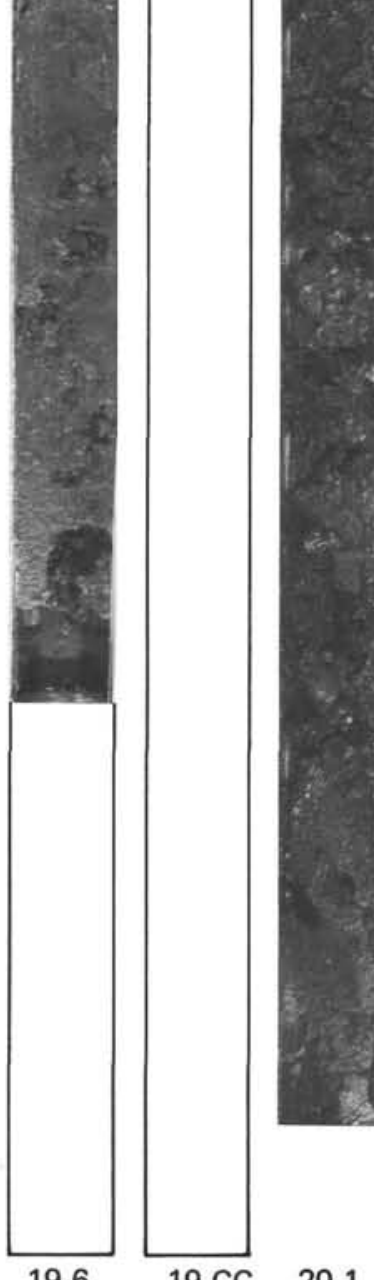

19-6
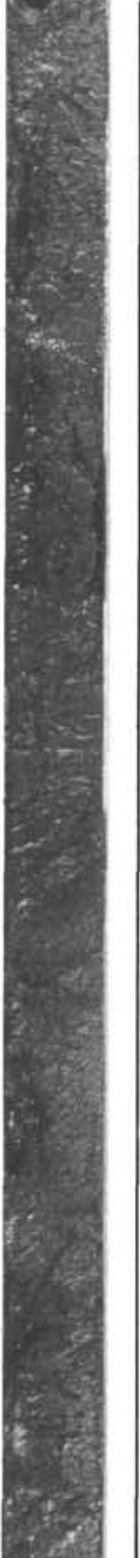

19,CC
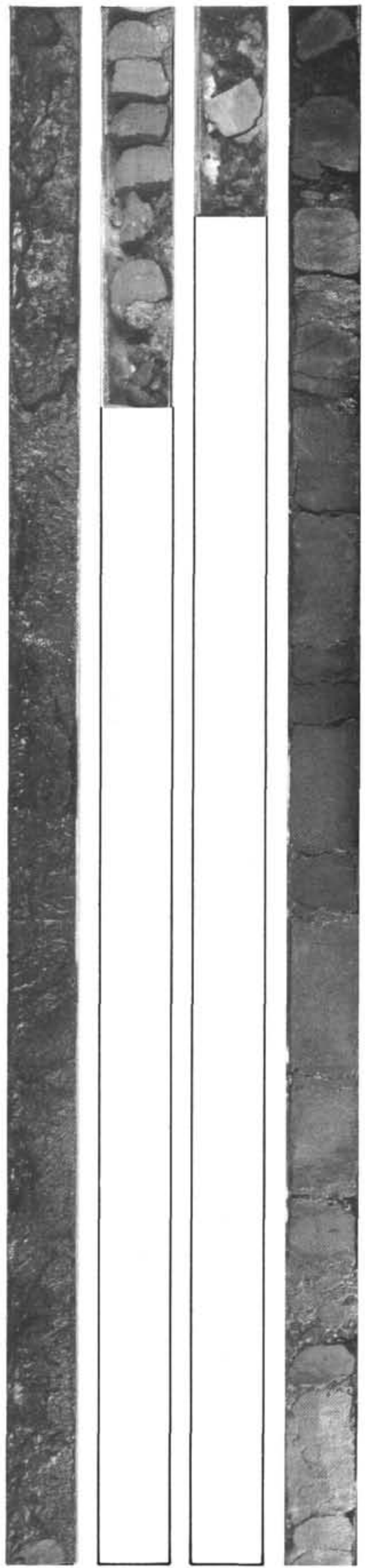
Hole 450
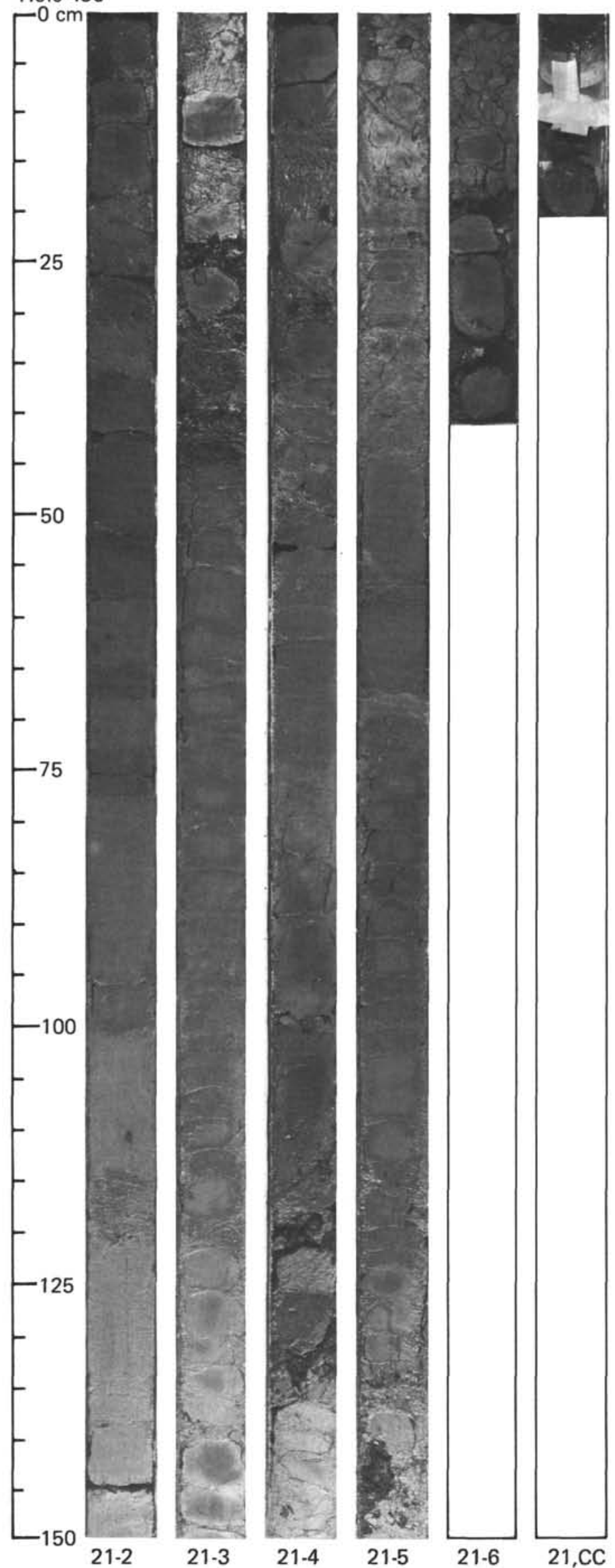

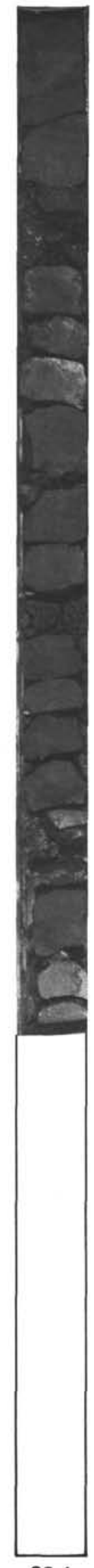

22-1

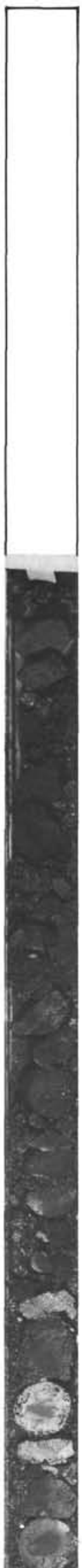

$22-3$
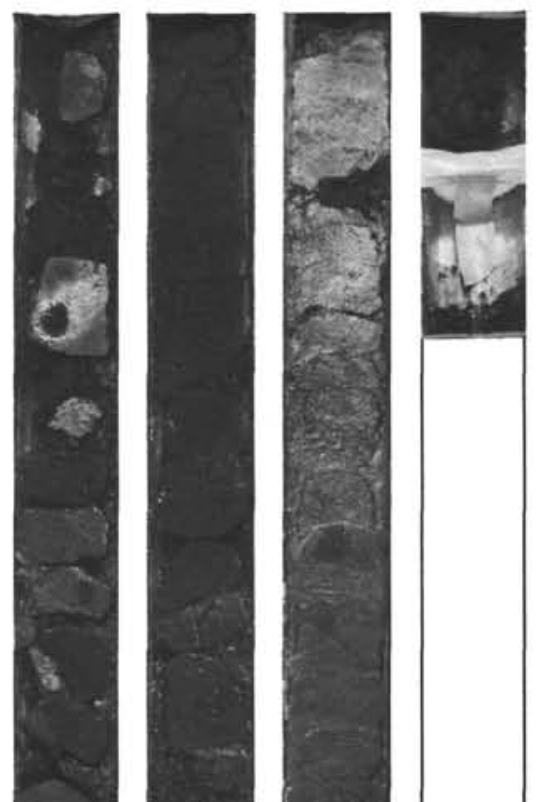
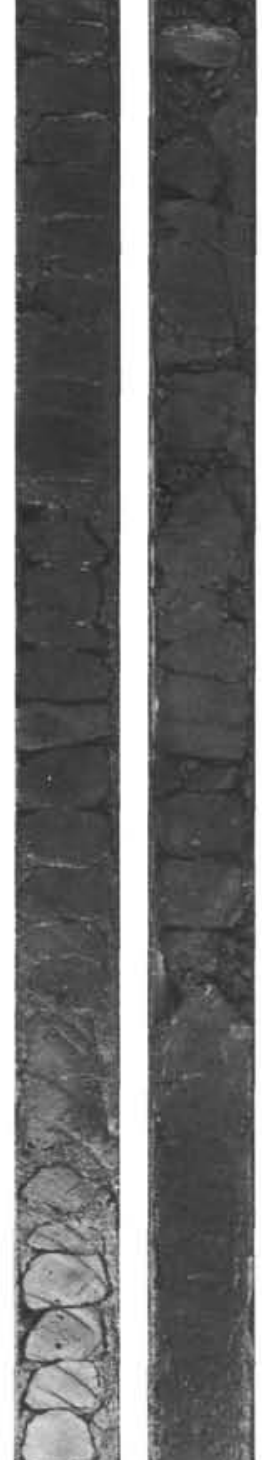

22-4

$22-5$

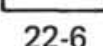


Hole 450

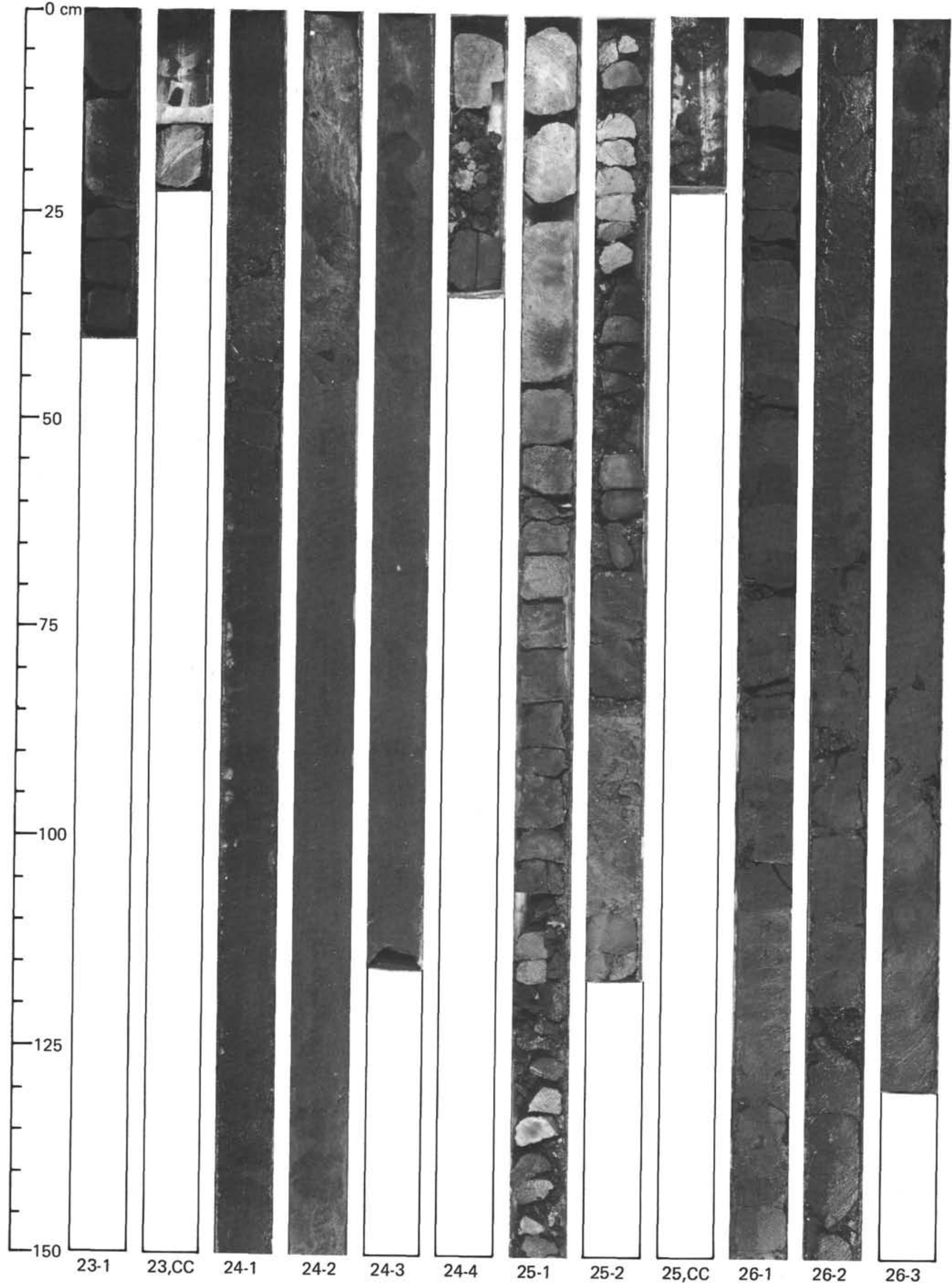


Hole 450

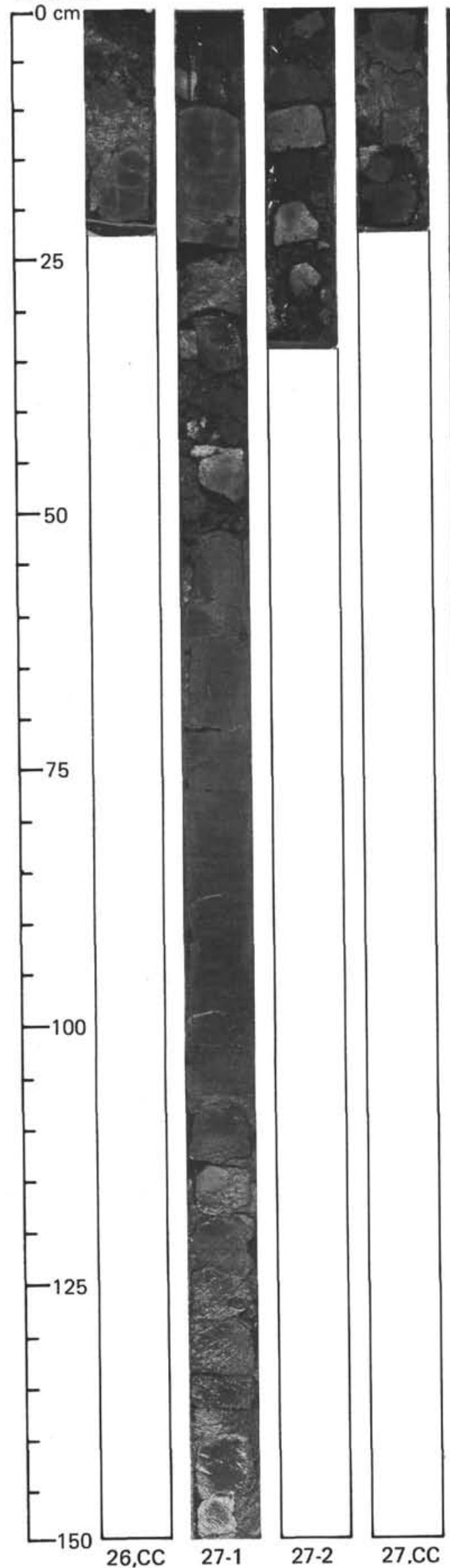

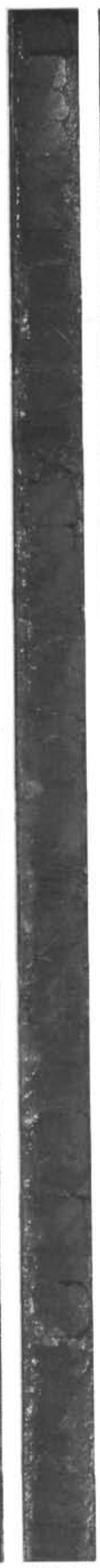

$28-2$

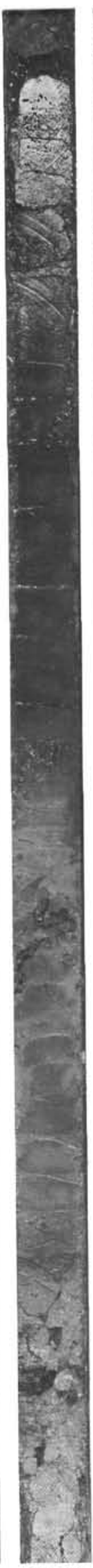

28-3

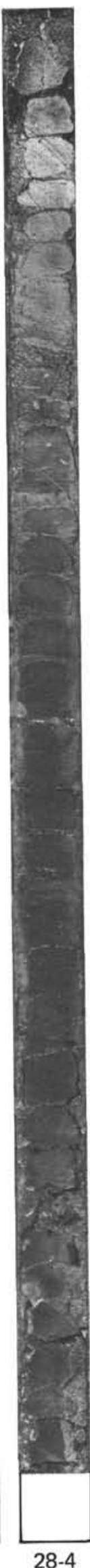

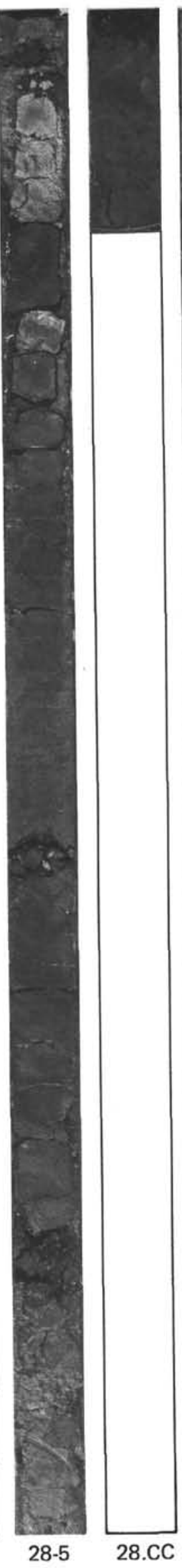

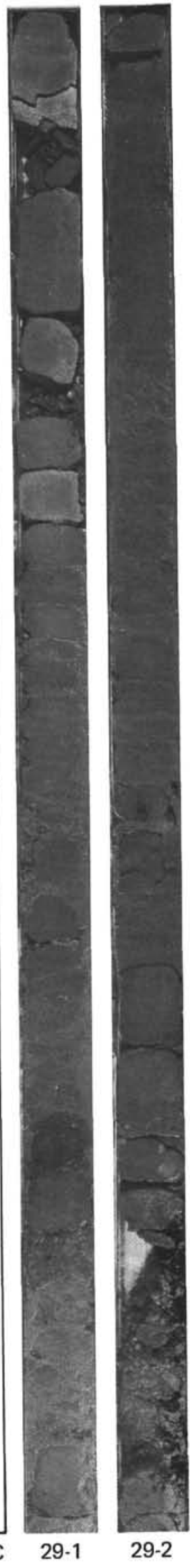


Hole 450

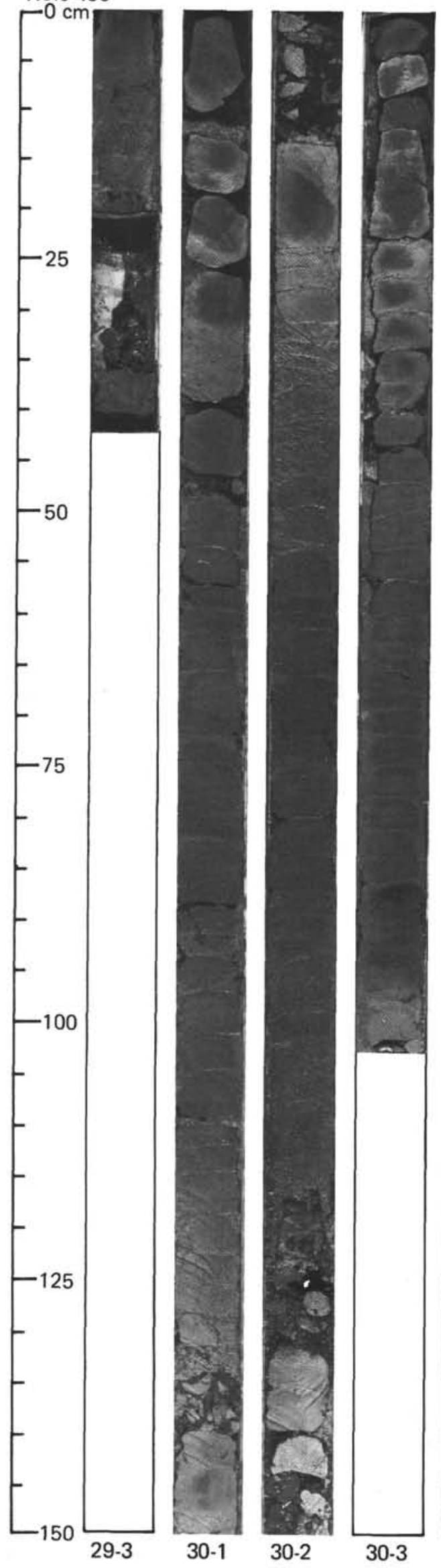

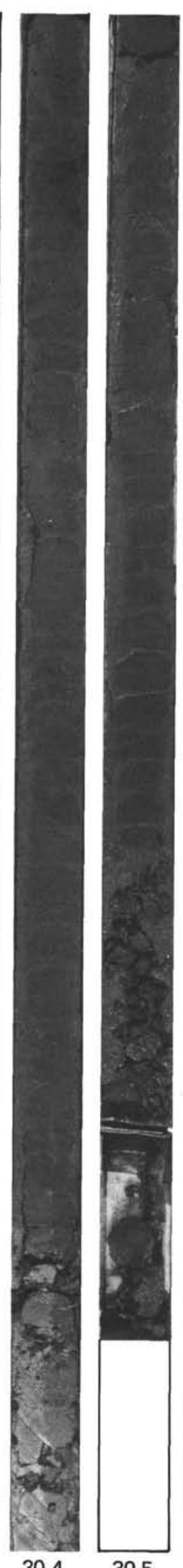

30-4

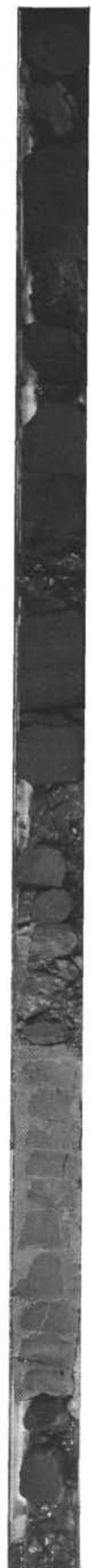

$31-1$

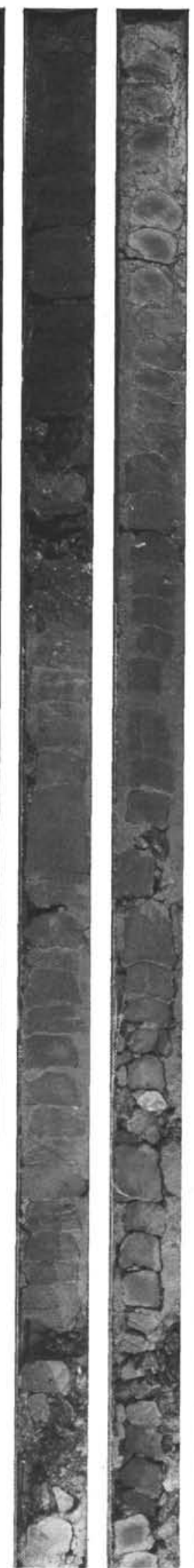

31-2
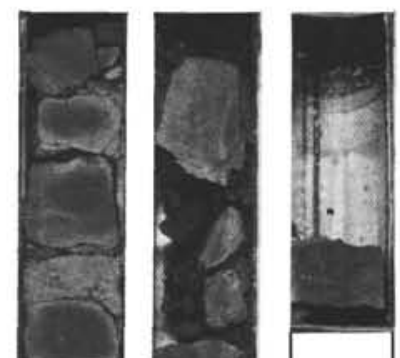

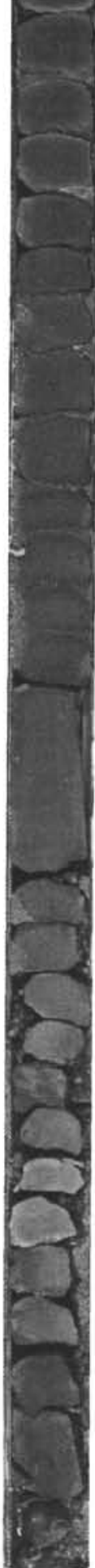

31.4
31-5 


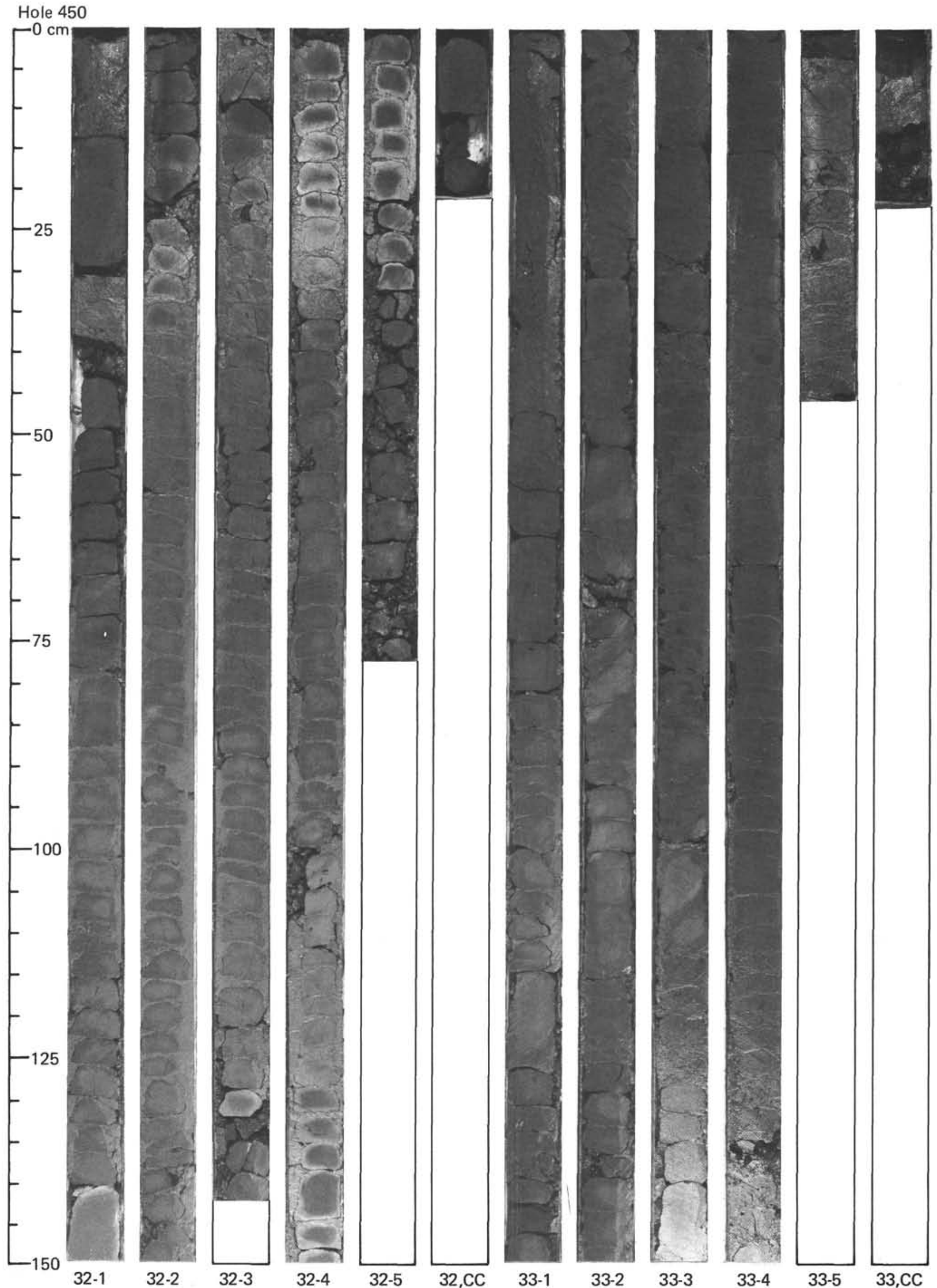


Hole 450

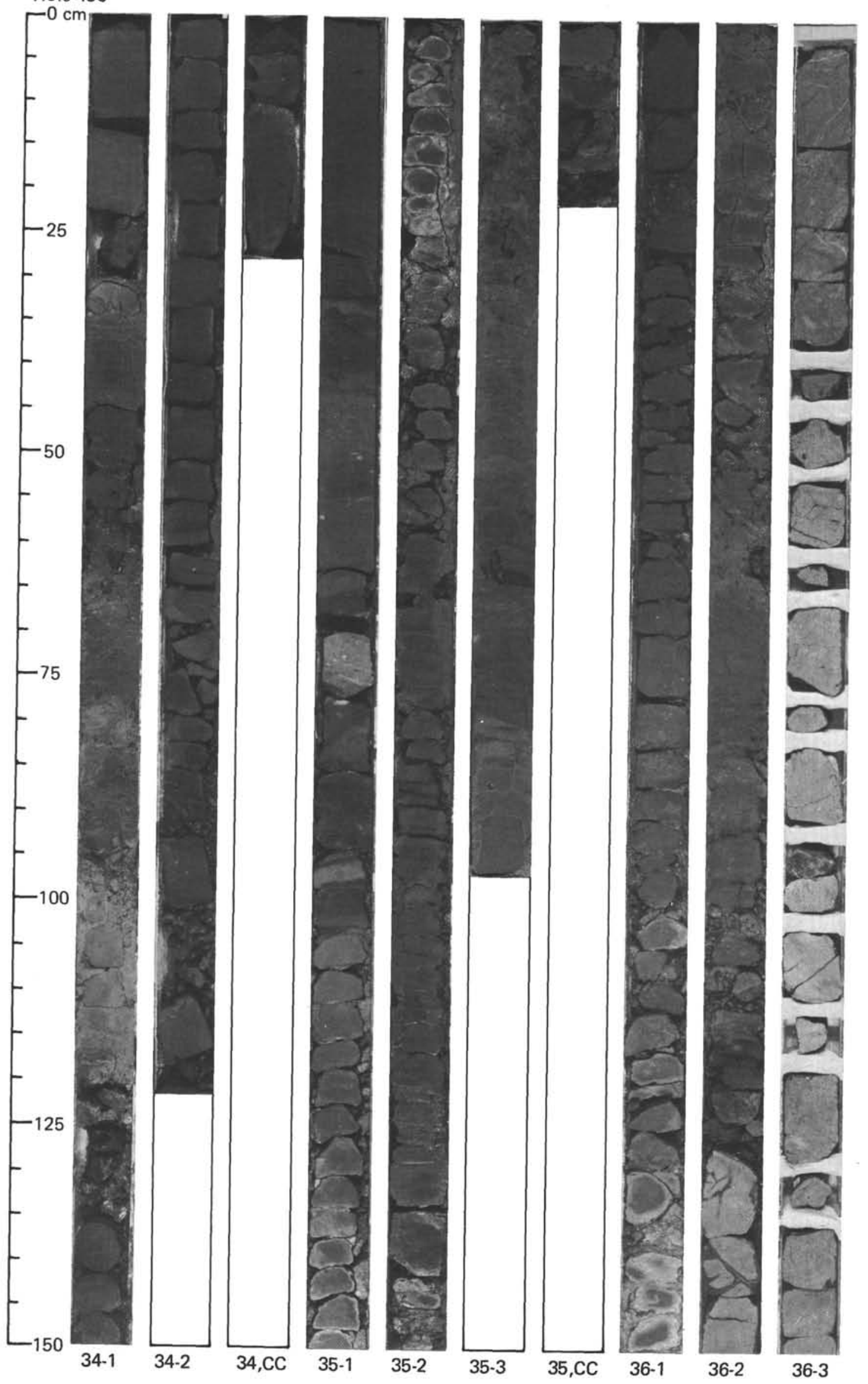

